\title{
A MIXED METHOD PHENOMENOLOGICAL CASE STUDY OF HOW MEMBERS OF A DEMOCRATIC MICRO SCHOOL EXPERIENCE LEADERSHIP AND DEMOCRATIC PRINCIPLES
}

\begin{tabular}{c} 
A Dissertation \\
Presented to \\
the Faculty of the Graduate School \\
at University of Missouri- Columbia \\
\hline
\end{tabular}

In Partial Fulfilment of the Requirements

for the Degree

Doctor of Education

by

TARA J. BONEBRAKE

Dr. Jeffrey H. D. Cornelius-White, Dissertation Advisor

May 2019 
The undersigned, appointed by the dean of the Graduate School, have examined the dissertation entitled

\section{A MIXED METHOD PHENOMENOLOGICAL CASE STUDY OF HOW MEMBERS OF A DEMOCRATIC MICRO SCHOOL EXPERIENCE LEADERSHIP AND DEMOCRATIC PRINCIPLES}

presented by Tara J. Bonebrake

a candidate for the degree of Doctor of Education, and hereby certify that, in their opinion, it is worthy of acceptance.

Dr.Jeffrey Cornelius-White

Dr. Cynthia J. MacGregor

Dr. Kim Finch

Dr. Patricia "T.C." Wall 


\section{ACKNOWLEDGEMENTS}

First and foremost, I would like to express my sincerest gratitude to those who walked both the course based and dissertation journey with me. Dr. Jeffrey CorneliusWhite provided thoughtful commentary, feedback, and support throughout my dissertation journey. His guidance and understanding proved invaluable. Additionally, I'd like to expressly thank Dr. Cynthia MacGregor, who fearlessly led our Missouri State EdD cohort and provided encouragement that expanded views and horizons. Dr. Finch and Dr. Wall were invaluable in providing K-12 perspective and thoughts to my research. I am truly grateful to have had them on my committee. Dana, Angie, and Callie, my dissertation group, are amazing women who truly supported me and provided great friendship. Ladies, thank you so very much for travelling the dissertation road with me.

To my village, the completion of this degree is as much your success as it is mine. The gratitude I owe to this amazing group of people is enormous. My husband Wes, who helped hold down the home front and cheered me on every step of the way. To Price and his pronouncement of "disrotation", someday I hope you truly understand what completing this process means. To my parents, thank you so much for your continual support of my academic aspirations. To the faculty and staff with whom I work, thank you.

I am incredibly lucky to be surrounded by amazing energy and people. Those relationships continually help me to define who I am, what I want to do, and who I want to be. Thank you. 


\section{TABLE OF CONTENTS}

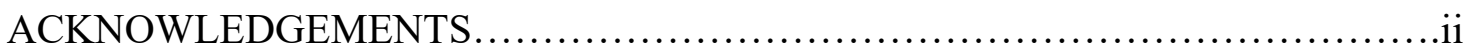

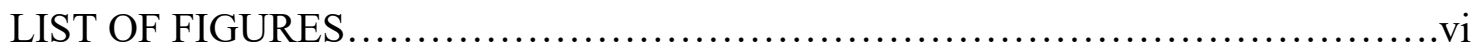

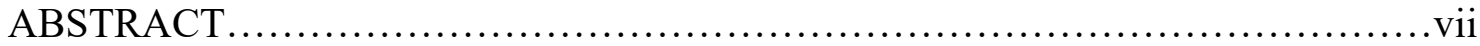

\section{SECTION ONE}

Introduction..........................................................

Statement of Problem.............................................6

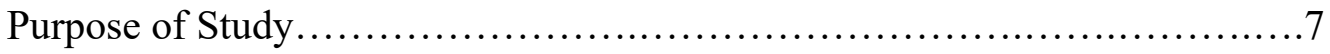

Research Questions..............................................8

Theoretical Framework............................................. 8

Design of the Study................................................... 13

Limitations, Assumptions, and Design Controls.........................22

Definitions of Key Terms........................................22

Significance of Study ...........................................23

○ Scholarship................................................24

$\circ \quad$ Practice......................................................24

Summary..................................................... 25

SECTION TWO- PRACTIONER SETTING FOR STUDY $\ldots \ldots \ldots \ldots \ldots \ldots \ldots \ldots \ldots . . . \ldots 27$

History of the Organization..........................................28

Organizational Analysis............................................ 30

Implications.......................................................

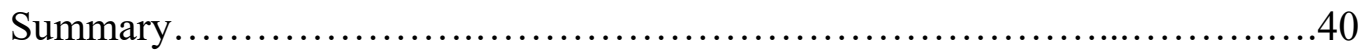

SECTION THREE- SCHOLARLY REVIEW $\ldots \ldots \ldots \ldots \ldots \ldots \ldots \ldots \ldots \ldots \ldots \ldots \ldots . \ldots . \ldots \ldots$ 
Introduction.

Privatization and Democratic Schools....................................44

Democratic Schools..................................................49

Leadership in Democratic Schools.......................................54

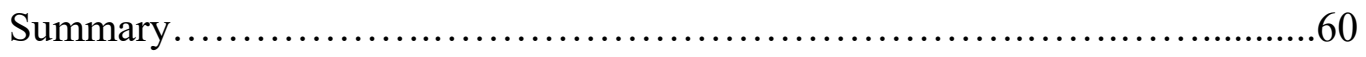

SECTION FOUR- CONTRIBUTION TO PRACTICE............................63

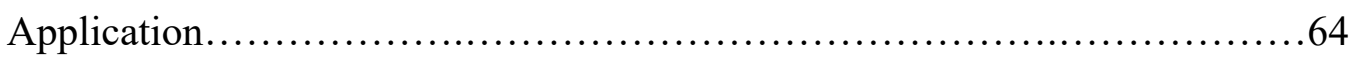

Presentation......................................................66

SECTION FIVE- CONTRIBUTION TO SCHOLARSHIP .........................73

Abstract........................................................... 75

Introduction.......................................................... 76

Research Question.................................................81

Methods............................................................... 82

Findings........................................................ 87

Discussion............................................................. 103

Conclusion, Implications and Limitations................................108

References...................................................... 109

SECTION SIX- REFLECTION ............................................... 113

Introduction.................................................... 114

How the Dissertation Impacted My Practice as an Educational Leader........114

How the Dissertation Impacted Me as a Scholar.........................117

Infographic.................................................... 118

The Journey is Incomplete: Conclusion or Beginning?...............................122 
REFERENCES........................................................ 123

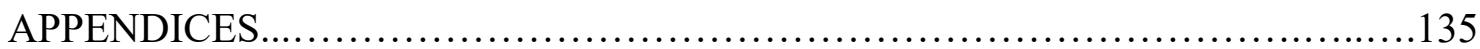

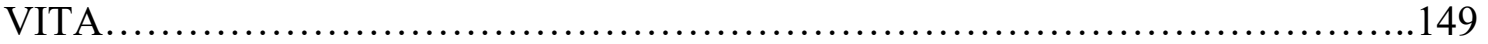




\section{LIST OF FIGURES}

\section{SECTION ONE}

Figure 1. Leadership Components of a Democratic School...................11

\section{SECTION THREE}

Figure 1. New Learning Models as Alternatives to Traditional Public and Independent Schools.................................................... 48

\section{SECTION FIVE}

Figure 1. Leadership Components of a Democratic School....................79

Figure 2. Reimagining of leadership and democratic principles in a democratic micro school considering the research findings.............................103

\section{SECTION SIX}

Figure 1. The reflection of four years in an infographic.....................118 


\title{
A MIXED METHOD PHENOMENOLOGICAL CASE STUDY OF HOW MEMBERS OF A DEMOCRATIC MICRO SCHOOL EXPERIENCE LEADERSHIP AND DEMOCRATIC PRINCIPLES
}

Tara J. Bonebrake

Dr. Jeffrey Cornelius-White Supervisor

\begin{abstract}
A democratic micro school is a school with fewer than 150 students that ascribes to a democratic leadership structure where all of the school community members, especially the students, have leadership in their learning. The purpose of this study was to develop a better understanding of the lived experiences of the members of a democratic micro school community, especially regarding leadership and democratic principles. The primary researcher used a mixed-method design with an embedded phenomenological case study to analyze a single democratic micro school. All primary stakeholders in the school community were subjects of this study which included the students, parents, and educators. The data collection process included a survey, focus groups, interviews, observations, and other school artifacts. Using six democratic principles and the LMX theory, this study to added to the literature by addressing the experiences of those individuals attending independent schools. Achieving democracy in school allows students and teachers to have control of their learning experiences. This study supported the importance of communication and trust and caring as the educational foundation upon which equity, curriculum and interests, vision and goals, and community relied. Future research could expand the understanding of democratic micro schools beyond the single case used in this study.
\end{abstract}




\section{SECTION ONE}

INTRODUCTION TO THE DISSERTATION 
The privatization movement of education has gained significant momentum in the current political environment (Colombo, 2017; Darling-Hammond, 2017). This movement, with an increase in dissatisfaction with public school success, has led to a number of democratic micro school environments (Colombo, 2017; Prothero, 2016; Tanz, 2015). As of 2015, the independent school market accounts for a little more than $10 \%$ of the education of kindergarten-12th grade students in the United States (McFarland, 2018). Over the last 10 years, the student population of independent schools has accounted for between $9.6 \%$ and $11.7 \%$ of the school aged children in the United States. The current agenda in the Department of Education may encourage an increase in the number of students attending independent school. In the fiscal year 2019 federal budget proposal, President Trump recommended a $\$ 1.6$ billion increase in spending on private school vouchers and other school choice programs (Balinget et al., 2018). Regardless of whether the current administration's focus on privatization shifts the predicted downward trend, there are schools and individuals accepting the challenge of meeting the needs of today's growing independent school opportunities in the United States.

At the center of the dramatic shift in public schooling in the United States is an administration that supports increasing educational privatization (Carpenter \& Kafer, 2012; Cooper \& Randall, 2008; Darling-Hammond, 2017; Egalite \& Wolf, 2016). Privatization of public school is happening not in the form of publicly funded charter schools but rather in the form of voucher systems and subsidizing for profit educational management companies (Colombo, 2017; Egalite \& Wolf, 2016). In direct contrast are independent schools with non-publicly funded tuition, donation, sponsored, and fund- 
raising base (Dronkers \& Robert, 2008). One of the most significant concerns about this shift is movement of public funds into the private sector, whose consequences are most significant for minorities and economically disadvantaged students (Cooper \& Randall, 2008; Darling-Hammond, 2017). The consequence of this could very well lead to increased stratification of educational opportunities for students (Darling-Hammond, 2017; Eckes, Mead, \& Ulm, 2016). However, perhaps more significant is the increased interest in education by entrepreneurs who may be able to privately fund school opportunities that allow for focused movement towards diversity in the emerging independent school sector (Horn, 2015; Tanz, 2015).

Traditional independent school models in the United States could be defined as mission driven, board-supported institutions having a history generally longer than 10 years (Dronkers \& Roberts, 2008; National Association of Independent Schools, n.d.; Schuermann \& McGovern, 2016). Of increasing interest are the number of new independent schools around the country, fewer than 10 years old, that are testing the traditional model paradigm. Hoerle (2015) identified four trends that did not fit into the traditional independent school experience. The trends identified included "academically rigorous schools, personal learning schools, deeper learning schools, and online schools" (Hoerle, 2015, para. 2). The complexity of traditional independent schools and challenges in changing well-established culture may allow for smaller, newer, and more fluid democratic micro schools to gain significant market share.

As independent schools, democratic micro schools are in the unique position of not being dependent upon public funds for support. As such, they do not operate under the same testing and legislative accountability restraints as their publicly funded 
counterparts. This does not necessarily mean they are free of accountability as their student population has a choice about where and if they will spend money on K-12 education (Hoerle, 2015, 2017). The appearance of and movement towards fluid democratic micro school environments is fast becoming a significant selling point for the independent school market. Families will be looking for independent schools to move in new directions to support the growth and success of their children in learning and beyond. Considering the expected decline in student population, the continued existence of independent schools will depend upon the population's willingness to spend money for K-12 education or for increasing the amount of government subsidies to help families afford tuition-based academic programs (Aurini \& Quirke, 2011; Colombo, 2017).

In addition to the four key school models gaining a foothold in the independent school market (Hoerle, 2015), the Online Education Strategies for Independent Schools (OESIS) published a study outlining key attributes for innovative aspirations for educational programming in schools (Ratnavale, 2017). Within these aspirations, pedagogical models included: "interdisciplinary approaches, competency based, online and blended learning, problem based learning (PBL), science, technology, engineering, and math (STEM) or science, technology, engineering, arts, and math (STEAM), emphasis on computer science and programming, entrepreneurship, maker-based, and designed thinking" (Ratnavale, 2017, p. 19). While this list is not exhaustive, the traditional education model is quickly losing ground to these pedagogies (Hoerle, 2015).

The micro school demonstrates the ability to blend different instructional design and pedagogy (Horn, 2015; Prothero, 2016). Micro schools share many of the characteristics identified in the Ratnavale (2017) study as well as the characteristics 
identified by Hoerle (2015). As such, the size of the micro school (fewer than 150 students) makes it an ideal environment to study different pedagogies. While the democratic school model is not a new model, a resurgence of interest in this model provides a strong platform for the explorations and experience described by Hoerle (2015) and Ratnavele (2017). Combining the fluidity and flexibility of a micro school with a focus on a democratic learning model has the potential to increase student interest in learning and increase parent interest (DiPerna \& Catt, 2016). The case in this dissertation study, a democratic micro school, may use any of the above pedagogies to establish academically rigorous schools, personal learning schools, deeper learning schools, and online schools (Hoerle, 2015; Ratnavale, 2017).

Beyond the tuition base, many of these schools are fundraising, writing grants, and receiving private endowments to support their mission and varied academic models. Increasing privatization might provide the increase in opportunity needed for families seeking emergent educational experiences for their children. However, the research on the effectiveness of increased opportunity due to school choice is mixed at best (Colombo, 2017; Darling-Hammond, 2017; McShane \& Eden, 2015). Increasing diversity is an important consideration and many independent schools have enacted plans to increase diversity of their student populations. As democratic micro schools continue to grow, diversity could be an important factor in supporting their sustainability and growth.

Leadership is the role of an individual to influence, support, and encourage a group to work towards a common goal (Bush, 2011; Goleman, 1996/2011; Levi, 2014; Northouse, 2016). In the democratic micro school environment, new leaders are 
emerging, not from the annals of academia, but from giant corporations. Many founders of several well-known democratic micro schools rose through the ranks of technology companies where they became concerned about the state of education in the United States (Horn, 2015; Lapowsky, 2015; Tanz, 2015). Not only are individuals from technology companies founding schools but they are also supporting non-traditional leaders in founding new and different educational experiences (Conklin, 2017; Leadership for Educational Equity, 2017). As new schools come into existence, such as the democratic micro school, it is important to increase an understanding how the members of a democratic micro school community experience leadership.

\section{Statement of the Problem}

In the growing school choice market, an increase of both public and independent options for students and families has occurred. In addressing public concerns about the state of education in the United States, new school models continue to emerge (Cooper \& Randall, 2008; Edwards, 2014; Hoerle, 2015; Prothero, 2015). One significant difference between traditionally publicly- funded schools and independent schools is the required adherence to district, state, and national policy (Jorgenson, 2006; Shakeel \& DeAngelis, 2017). This increased latitude with instructional programming opportunities has seen increased attention to different learning models (Hoerle, 2015/2017; Horn, 2015; Ratnavale, 2017). If grounded in solid educational theory, these models could be a needed change to shift education in the United States. The development and implementation of these models is recent, mostly occurring within the last 10 years (Horn, 2015). The emergence of these democratic micro schools provides a strong platform for academic consideration. 
Acknowledging that school leadership influences successful student outcomes, increasing the body of academic knowledge about these democratic micro school environments is imperative (Bush \& Glover, 2014; Leithwood, Sun, \& Pollock, 2017). Information about the individuals founding these schools and their leadership is currently missing from academic literature. The practical application in addressing this "gap" in the literature is determining if there are common backgrounds and experiences necessary to found and lead in the democratic micro school climate. This study could serve to contribute to developing an understanding of the relationships, education, and experiences of those in the communities on the forefront of potential education reform. While there is information about the newly founded democratic micro schools, this information is found primarily in non-academic sources such as magazines and school websites. There is little to no information on how the relationships and experiences influenced individual decisions to be members of a democratic micro school.

This lack of academic research covering this specific type of school underscores a significant need to better understand the experiences of leadership in a democratic micro school. The applicability for developing this understanding will contribute to literature as well inform practice. This study will expand current literature about democratic schools by including the leadership experiences of the school's community members. Further, it will provide practical insight into the democratic school environment by considering all members of the school community.

\section{Purpose of Study}

The purpose of this study is to develop a better understanding of the lived experiences of the members of a democratic micro school, especially regarding 
leadership and democratic principles. Using a mixed-method design with an embedded phenomenological case study to analyze a single democratic micro school, this study will address how members of a democratic micro school community experience leadership and democratic principles. All primary stakeholders in the school community will be the subjects of this study and will include the school educators, students, and parents. The data collection process will include a survey, focus groups, observations, and general information found on the Internet.

\section{Research Question}

How do members of a democratic micro school experience leadership and democratic principles? Specifically, how do members experience leadership in terms of
a. communication
b. vision and goals
c. school community
d. equity
e. curriculum and interests
f. trust and caring

\section{Theoretical Framework}

Building relationships within the democratic school community would be an essential part of creating the opportunity for a democratic school to have a personal and deep learning focus (Hoerle, 2015; McCormick, 2017; Ratnavale, 2017; Woods \& Woods, 2012). Using the central principles identified for democratic schools and the theoretical model for the Leader Member Exchange (LMX) Theory, the researcher will 
establish a framework with which to help better understand how the members of a democratic school community experience leadership.

\section{Democratic School}

Hiatt-Michael (2001) identified four key components necessary for a learning community to exist: the existence of a servant leader, a shared purpose within the school community, a sense of trust and respect amongst the members of the school community, and an environment open to collaboration in the decision-making process. McCormick (2017) identified four key pillars to democratic education: inclusive decision-making, sense of community, shared vision and goals, and individual growth. In creating an analytical tool for studying democratic schools, Woods and Woods (2012) identified "four degrees of holistic democracy: transforming dialogue, holistic well-being, power sharing, holistic meaning" (p. 709).

Leadership may take on many forms in this environment. Inclusive decisionmaking is the process by which the school community is included in making important decisions relative to the school. These decisions could include curriculum, new student admission, board related decisions, etc. (McCormick, 2017; Woods \& Woods, 2012). The school community, in conjunction with the leadership, may decide the vision and goals. The communication of these goals is an important factor to the school community. In a democratic school, the vision and goals may also be established or edited by the school community (Woods \& Woods, 2015). Perhaps a significant crossover between the democratic schools and leadership may present itself in the philosophy of leadership of the scholar practitioner (Schultz, 2010). The core values of Schultz's (2010) theory are "community, democracy, social justice, caring, and equity" (p. 52). 


\section{Leadership}

The Leader-Member Exchange Theory (LMX) focuses on the relationship building characteristics and focus of leaders and followers (Northouse, 2016). When considering the role of deep learning in a micro school, the connection between leaders and followers (students) is to have established a strong committed relationship to the learning process. In addition to building strong relationships with followers, LMX theorizes that the followers can be divided into an "in-group" and "out-group" (Northouse, 2016). However, the existence of these two groups may be mitigated by high-quality exchanges between the leader and the members. Northouse (2016) described the LMX Theory as working in two ways: "it describes and prescribes leadership" (p.144).

Brower, Schoorman, \& Tan (2000) focused their research of the LMX theory on the relationship between leader and subordinate. Their model introduces the idea of trust into the relational components of the LMX Theory. In the democratic micro school being studied for this project, while the structure is considered flat, there may or may not be the existence of power differentials between the students and the educators. A central theme to a democratic school would be how the members of the school organize learning, develop plans based on interests, and follow a path which informs curriculum (Wallin, 2003; Woyach, 1992). How these individuals perceive trust could further help inform the existence of different groups within the democratic micro school environment.

\section{Model}

From the key themes identified as democratic schools and those central to the LMX Theory, the researcher has established six key principles that would be essential to 
understanding how leadership is experienced in a democratic micro school. The main principles of the model include: communication, vision and goals, community, equity, curriculum and interests, and trust and caring (Hiatt-Michael, 2002; Hoerle, 2015; McCormick, 2017; Northouse, 2016; Ratnavale, 2017; Woods \& Woods, 2015). Figure 1 shows the connection between the central themes of LMX Theory and the key principles in a democratic micro school.

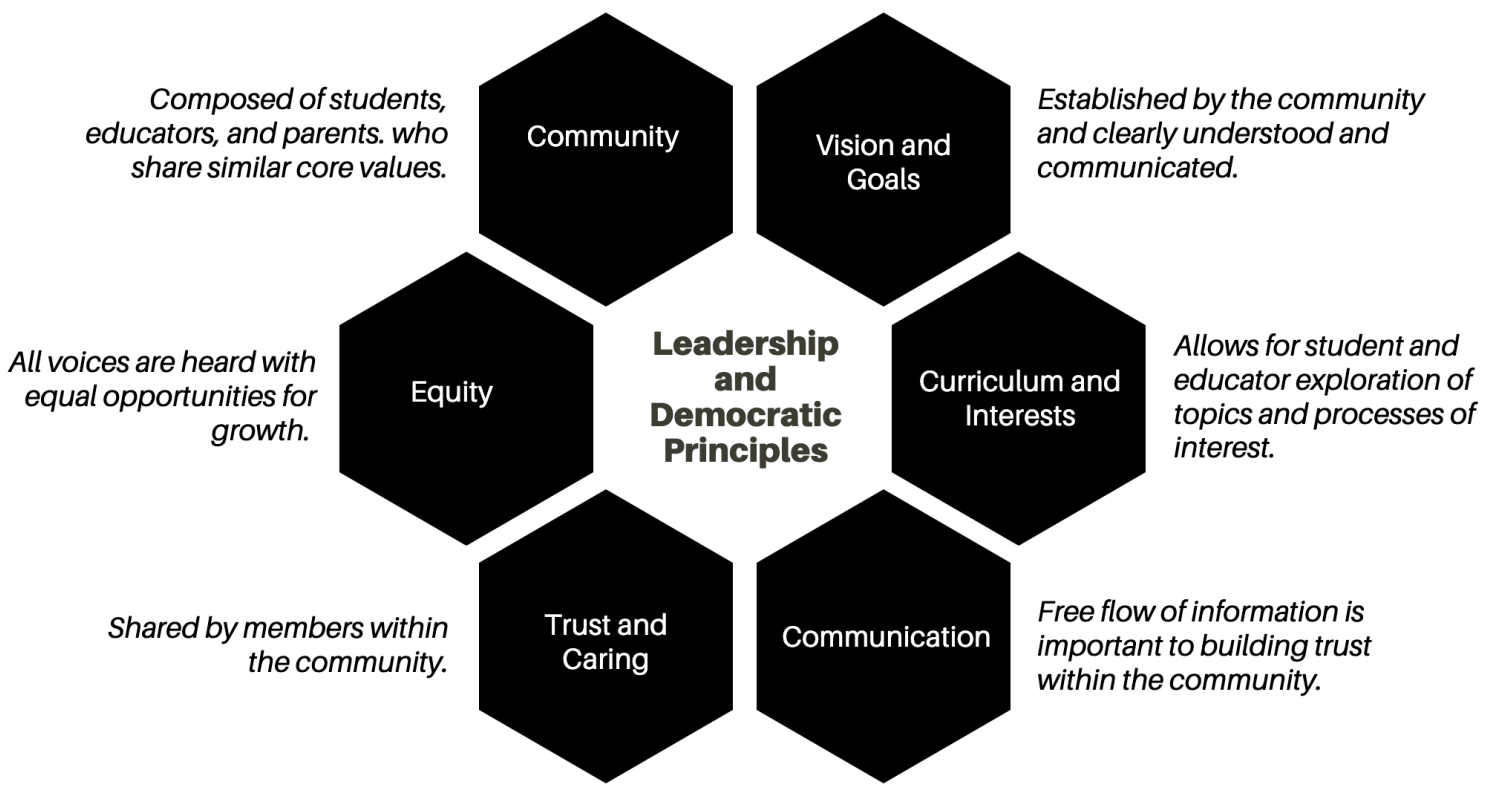

Figure 1. Leadership Components of a Democratic School.

Synthesis of LMX theory and democratic micro school. Summarizes the central components of both leadership and the democratic school. These six components represent the intersection of LMX Theory and democratic micro school philosophy (Hiatt-Michael, 2002; Hoerle, 2015; McCormick, 2017; Northouse, 2016; Ratnavale, 2017; Woods \& Woods, 2015).

\section{Model Definitions}

Trust and caring. Helps to describe the important sense of "belongingness" needed to be a part of the school community as well as addresses a central theme to the LMX Theory in that trust is an important factor between leader and members of the organization (Schulte, Shanahan, Anderson, \& Sides, 2003). Further, Hatch and Shultz 
(2002) described that the important factor for caring relates to how people within an organization take responsibility for each other. The democratic school model is one where the school community works together to plan, design, and create their learning process; this works most positively when trust and caring exist between the members.

Community. The students, parents, and educators are the individuals who compose the organization.

Equity. In a flat leadership structure, all voices should be heard on equal ground, regardless of who is speaking (Preskill \& Brookfield, 2009; Hatch \& Schultz, 2002). Who is being heard and how they are being heard is an essential part of leadership in a democratic school.

Communication. Communication is an essential part to the success of any organization. In a democratic school, the lines of communication are plentiful as this tenet is a necessity for success in the other five. Omilion-Hodges and Baker (2017), found that the type of communicative exchanges that took place between leader and members played a large role in determining the relationship shared between leader and member.

Curriculum and interests. A central tenet to the democratic school philosophy is the right to self-determination in studies and experiences (Korkmaz \& Erden; 2014; Woods \& Woods, 2012). As democratic schools focus on giving students free choice in their learning, allowing students to design and follow their interests and being supported within their endeavor is an important factor.

Vision and goals. McCormick (2017) and Woods and Woods (2012) identified the necessity of the members to work together to create a vision and set goals. This is a 
key component for any democratic school as it involves collaboration and working together to create a vision and path for the future of the school.

\section{Design of the Study}

This study used an embedded mixed method design, including a phenomenological case study to consider the experiences of the school community members. Further, a survey was embedded as part of the case study (Creswell, 2014; Yin, 2014). Together, descriptive statistical analysis, interviews, and document analysis provided a rich phenomenological description of the experiences of the school community members within the context of the democratic micro school. A phenomenological study emphasizes the shared experiences of several individuals (Creswell \& Poth, 2018; Merriam \& Tisdell, 2016; Moustakas, 1994). The shared experiences of the members of the democratic micro school were the primary focus. Patton (2015) described phenomenological studies as those that sought to describe the meaning of common lived experiences and that there is an importance to understanding this phenomenon. Merriam and Tisdell (2016) stated "the task of the phenomenologist is to depict the essence or basic structure of experience" (p. 26). Descriptive statistics were used to better understand how members experience leadership as both leaders and followers in the democratic micro school. The members of the school community were divided into different groups based on their roles within the school. The roles were those of educators, students, and parents.

The convergence of using a mixed method phenomenological case study designed to explore the lived experiences of the school community for the purpose of this research was to be revelatory in addressing the emergence of a new school (Merriam \& Tisdell, 
2016; Y in, 2014). The case for this research began its third year of operation in the fall of the 2018. Further, the process of phenomenology requires the researcher to bracket personal experiences to allow for a deeper understanding of the phenomenon being studied (Merriam \& Tisdell, 2016; Moustakas, 1994). For this study, the participants, all types of members of the school community, shared their lived experiences of leadership as members within the context of a democratic micro school.

A phenomenological case study suits studying the experiences of the school community members within the three key facets of a democratic micro school: democracy, leadership, and community. This method was used to better understand the essence of the relationships and shared experiences of the democratic micro school community within the organization's structural constructs (Creswell \& Poth, 2018; Merriam \& Tisdell, 2016; Northouse, 2016). In considering these aspects within the context of a revelatory case study, the phenomenon of leadership and community in a democratic micro school provided a new avenue to better understand the experiences in founding a new school.

\section{Setting}

The setting for this study was a democratic micro school that serves students ages 12 and over in a mid-sized Midwestern community. This age range typically represents grades seven through twelve in a traditional school setting. However, the school used in this study does not assign students to grades but rather focuses on individual learning and growth (Organization Website). The surrounding community has approximately 10 independent schools of varying sizes. Further, there is an academically strong presence in the surrounding public schools in providing the rigorous curriculum offered in the 
middle and upper level International Baccalaureate programs. The organizational website shared that the school was founded by "Three teachers who wanted a school that not only reflected what cognitive research suggests for teenagers but also what their teaching experience showed" created the school (Organization Website).

Because the school is so new, it was in the process of self-monitoring in order to work towards accreditation (Organization Website). The school further describes itself as a "private, independent secondary school using a democratic model” (Organization Website). The school structure and focus were created and supported by the students, teachers, and parents. A weekly meeting takes place to make decisions about curriculum and day-to-day educational activities. As an expression of its democracy, each school community member is given equal opportunity to voice ideas and vote on activities.

The school relies almost entirely on tuition to sustain itself. It has been designed to have a very low overhead by occupying primarily public spaces. Further, the school does offer financial assistance and hopes to attract students and families from underserved and underrepresented communities. The school frames its academic learning model within the context of state-generated standards but admits that the selfdirected nature of its programming allows for increased latitude and choice for the students, teachers, and families. Further, the school also uses the community as part of its education structure by using workshops, activities, and other opportunities provided by community organizations.

\section{Participants}

The participants in this study included the key members in the school's community. These were: the educators of the school, the students who are members of 
the student body, and the parents. The goal was to have representatives of all members of the school community participate in some aspect of this study. Participants were recruited from the school community with the goal of meeting with the majority of members in one setting at one time. As the study was a phenomenological study, the participants were considered co-researchers, whose opportunity suits the constructs of the democratic micro school (McCormick, 2017; Moustakas, 1994; Yin, 2014).

The school community members were initially contacted through the school information process (website), school meeting, and through email to complete the survey. At the conclusion of the survey, participants were asked if they would be interested in participating in a focus group. Those interested in participating in the focus group were asked to supply a best method of contact (email, text, or phone call) and then contacted accordingly. If this group had been a large number of individuals, convenience sampling would have been necessary. Purposive sampling involved choosing the individuals who provided thoughtful and descriptive responses to support greater depth of understanding of the case being study (Merriam \& Tisdell, 2016).

Educators. The roll of the educators in the school was to provide "guidance, workshops, mini lessons, directed instruction, feedback, and direction" (Organization Website). All four educators, the academic leaders of the school, were asked to participate in the study. Because of the small number of school leaders, sampling was unnecessary and would be a mistake as the lived experiences of these individuals was the primary focus of this study (Fink, 2017). These individuals were contacted by email as well as in person. Their participation included both the survey and focus group. The educators were also given a consent form found in Appendix A. 
Parents. These were the individuals making the choice to send their child(ren) to this school. In this school community, the number of parents was between 30 and 40 . These individuals were initially contacted through school information process and through email to complete the survey. The target number of parent participants in the survey was 18. From this, the goal was to form a focus group between 5-10 parents. Parents were given the same consent form as the educators, found in Appendix A.

Students. Students' experiences of leadership in a democratic micro school were important as they were at the center of the school community. The student population of this democratic micro school was composed of children ages 12 and over. The students who were minors needed to have parent consent to participate in the study (Appendix B). Student participants were recruited in person and were given an assent form also found in Appendix B. In order to participate in the survey and focus groups, both consent and assent was obtained. Student assent followed parent consent. For the 2018-2019 school year, the school had an enrollment of 25 students. All students were asked to complete the survey (after parental consent) and the target was at least 18 students. The target for the focus group was 5-10 students. If more than 10 wanted to participate and were given permission to do so, then the researcher planned to have two focus groups of students. The nature of this school was such that student participation in this study was considered a learning process and treated as such by the researcher.

\section{Data Collection}

In order to increase the validity of this study, data was collected from multiple sources and through multiple means (Creswell, 2014; Merriam \& Tisdell, 2016; Yin, 2014). The primary types of data collected included public data collected from the 
school web page, survey data, focus group data, and observations. The role of the mixed method study was to present the most complete picture possible using the data sources that allowed the findings to "make sense" (Creswell, 2014). Descriptive statistics were used for the survey data. The focus groups provided a deeper more detailed account of the experiences of the school community members. "The task of phenomenologist, then, is to depict the essence or basic structure of experience" (Merriam \& Tisdell, 2016, p. 26).

Artifacts. The artifact data were collected from the school website. Data collected served to clearly define the setting, the academic interest and curriculum, admissions process, tuition, instructional processes, demographics, lesson plans, course guides, syllabus, daily schedule, and mission and values.

Survey. For this project, the survey served as a way to assess the relationship between the school community members and the leaders. The focus of the survey was to rate various thoughts and experiences as they pertain to the democratic school community, trust and caring, communication, curriculum and interests, equity, and vision and goals. The "descriptive statistics provide(d) simple summaries about the sample and the responses to some or all of the questions" (Fink, 2017, p. 137). Collection of survey responses was finished before the focus groups were formed in order to help compose focus groups as well as to potentially inform questions for the focus groups. Survey Questions can be found in Appendix C.

Focus Groups. Data collection from students, parents, and educators used a focus group method. As one significant factor of this study was school community, a focus group methodology allowed students, educators, and parents to share their ideas, 
and perceptions within that construct of the democratic micro school (Krueger \& Casey, 2015). In choosing to compose three different focus groups with students, educators, and parents, the focus groups allowed for exploration of the group experiences the six factors identified in Figure 1.

Since the democratic micro school environment is small, if a sample ended up being necessary, it was a convenience sample. Students and parents who were interested in participating were allowed to participate (Merriam \& Tisdell, 2016; Siedman, 2013). Depending on the number of interested individuals, in selecting participants, the goal was to have a representative purposive sample of both the student population and the parent population. Krueger and Casey (2015) suggested the perfect size for a focus a group is between 5-10 individuals. The focus group protocol can be viewed in Appendix D.

Observations. Observations were conducted during school meetings and during the regular school day. The observational data was collected concurrently with survey administration; however, the focus groups had not yet occurred (Creswell, 2014). The educators and students were the primary members observed unless parents or other outside individuals were also in attendance. The primary focus for the observations was the development of a better understanding of the day-to-day experiences of the school community members within the context of the six factors of the leadership experiences in the democratic school model. The observational focus can be found in Appendix E.

\section{Data Analysis}

The goal of data analysis was to make sense of data within the context of the chosen mixed method approach (Merriam \& Tisdell, 2016). The analysis of focus group data occurred using a phenomenological approach. The other unit of analysis used 
frequencies and percent of the survey data to provide a description of the members' experiences relative to the six key features shared in figure 1. Together, the data were analyzed using a side by side approach. Both the descriptive statistics and the focus group questions addressed community, vision and goals, communication, trust and caring, curriculum and interests, and equity. The descriptive statistics potentially addressed the broader views of the whole community while the focus groups allowed for the students, parents, and educators to share their thoughts and experiences.

First, to increase validity, triangulation was used by considering the multiple sources of data using constant comparison methodology (Creswell, 2014; Moustakas, 1994; Merriam \& Tisdell, 2016; Yin, 2014). Moustakas (1994) provided that "evidence from phenomenological research is derived from first-person reports of life experiences" (p. 93). As such, Moustakas (1994) described the steps in analyzing data. These included "Epoche, Phenomenological Reduction, Imaginative Variation, and Synthesis" (p. 93). The first step involved setting aside personal ideas and thoughts relative to the topic being studied (Epoche). Epoche is the preoperational stage of phenomenology (Merriam \& Tisdell, 2016; Moustakas, 1994). The second step described by Moustakas (1994) and Creswell (2014) is the process of phenomenological reduction. This process uses analysis of significant statements, the generation of meaning units, and the development of a description (Creswell, 2014; Moustakas, 1994). The process began with an in depth review of the data with open coding. Merriam and Tisdell (2016) described the process of primary coding as focusing on "patterns and insights related to the purpose and questions and guided by the theoretical frame" (p. 208). 
As the phenomenological frame focused on shared experiences, all artifacts were openly coded considering the research question and the six themes identified in Figure 1 (Merriam and Tisdell 2016). The next stage used will be imaginative variation, which considered the ideas and findings from reductive process from different angles (Moustakas, 1994). During this stage, other views of the data were sought with the ultimate goal of deriving a solid description of the phenomena. As part of this process, the units were analyzed for recurrence and categorization occurred. The categories emerged from the data but were strongly influenced by the central question (Merriam \& Tisdell, 2016). Once initial categories were identified each unit of data was assigned a category, and the process of revision and refinement took place. As refinement occurred, the research acknowledged "The essences of any experience are never totally exhausted... the synthesis represents the essences at a particular time and place from the vantage point of an individual researcher following exhaustive imaginative study of the phenomenon" (Moustakas, 1994, p. 109). Finally, in considering trends and categories across all data, the researcher further triangulated the data in order to provide a strong case study to support the findings (Creswell, 2014: Merriam \& Tisdell, 2016; Yin, 2014).

\section{Researcher Position and Ethical Considerations}

Interviews and observations provided the greatest threat to ethical actions (Merriam \& Tisdell, 2016; Siedman, 2013). As the observer and interviewer in this case, the researcher obtained consent for participation from both the parents and educators (Appendix E). As this study planned to also consider the experiences of minors (the students), consent was first obtained for the participation from a parent or guardian and then assent was obtained from the students whose parents gave consent (Appendix D). 
The process of doing was completed within the construct of the school's daily procedures by inviting students and educators to attend a community meeting and via an email with information to the parents. Moustakas (1994) identified participants in phenomenological studies as co-researchers with the ability to influence the processes of study and the ability to withdraw from the study at any time. Participants' concerns and comfort were considered very carefully and addressed as needed.

\section{Limitations, Assumptions, and Design Controls}

A limitation to this study was the use of only one location. The researcher hoped to mitigate this by providing rich description and details obtained from the members of the community. This study also adopted a narrow view of the community by including only those members directly involved with the school on a day-to-day basis, the students, the educators, and the teachers. The researcher was an outsider to this school, which could have limited the openness the members had towards answering the questions.

\section{Definitions of Key Terms}

- Independent School: A school that is funded primarily from tuition and generally also has an endowment for operational expenses. These schools typically do not have to follow state and federal mandates for curriculum and testing.

- Democratic School: A school that follows a democratic philosophy has a flat leadership structure with all individuals in the school community contributing to all aspects of school life.

- Leader Member Exchange Theory: Describes the relationships within an organization and addresses how the members interact with each other. 
- Micro School: This is a school with a student population of fewer than 150 students.

\section{Significance of Study}

More clearly defining the democratic micro school setting and the experiences of individuals leading in this environment could influence the scholarly study of practice and leadership. The gap in the literature pertaining to the school community of democratic micro schools is glaring. However, if these models successfully serve to educate students, their impact in the independent school market and public-school market will grow (Aurini \& Quirke, 2011). Having a clearer definition of the individuals leading in these emerging environments will serve the study of practice by defining and describing the role of leaders in these new models.

\section{Scholarship}

There is ample research about leading in the more traditional school environments (e.g., Baker, Campbell, \& Ostroff, 2016; Berends, 2015; Richardson, Beck, LaFrance, \& McLeod, 2016). Research about leaders in a democratic school is still nascent (McCormick, 2017). What is currently missing is solid purposive research about how leadership in a democratic micro school is experienced. The phenomenological study would provide an initial glimpse into how leadership is experienced by the students, educators, and parents in this school environment.

Given the rise of new school options for families, a better understanding of different school models is needed. The democratic micro school is one such model. As one example of a non-traditional independent school, developing an understanding of how leadership is experienced by members of the school community will contribute to 
current literature about democratic schools. In addition, this study will also expand the small amount of research about how leadership is experienced within the community of democratic micro schools.

\section{Practice}

Leading for school change to meet the needs of the 21 st century learner continues to be an important issue. Maintaining relevance and attracting students is a significant challenge for independent schools (Hoerle, 2017). One way a school might do this is to adopt or adapt curriculum that is considered innovative. Another option would be for a school to hire an individual who is either practiced in leading towards this shift or has the experiences that would enable them to inspire others to found a school or lead a school in a new direction. This study will serve the common threads these leaders share. For independent schools, this could inform who they might hire. For an individual, this might define what traits and relationships one might need to be considered for these experiences. 


\section{Summary}

The founding of schools using new and different learning models is on the rise (Butler, Carr, Toma, \& Zimmer, 2013; Hoerle, 2015). As millennial parents increase in number, their search for alternatives to the traditional public educational experience may also fuel the growth of both new schools as well changes in current models to meet their changing expectations (Chakrabati, 2016; Conklin, 2017; DiPerna \& Catt, 2016). Further, the current trend in diverting public education funds towards privatization may also fuel the founding and or evolution of schools to seek these funds (DarlingHammond, 2017; Eckes, Mead, \& Ulm, 2016). One such model that could potentially become more prevalent is the democratic micro school. Schools of this description provide a personalized learning experience for students that are typically absent from both traditional public and independent schools (Hoerle, 2015). Developing a better understanding of this model and its impact on the leadership behaviors of those in the democratic micro school community could both fill a gap in the literature as well as inform practice. There is an abundance of academic research on both traditional and independent schools; what is currently lacking are studies addressing the communities of new and different school models. This study will serve to address this absence as well as provide insight into the experiences of being a member a of democratic micro school community.

This study used a mixed method, phenomenological case study approach to describe how leadership is experienced by the members in democratic schools. In a democratic school model, each individual has a voice and right to share their thoughts and opinions (Korkmaz \& Erden, 2014; Morrison, 2005). Using a model based on 
current research on democratic schools and the Leader Member Exchange Theory, a better understanding of how leadership is experienced was developed. 
SECTION TWO

PRACTITIONER SETTING 
In discussing the foundation for creating a democratic school the Organization Website (2018) described its use of progressive models of education in conjunction with adolescent psychology in order to create an engaging and empowering setting for teenagers to grow and learn. There are several different factors that influence the school setting. The first is the community where the school is located and the human composition that establish the school. The next important factor is the facets that comprise a democratic school. Finally, situating this democratic school community within both organizational and leadership constructs will serve to establish this setting as a solid case for understanding the experiences of leadership within a democratic micro school community.

\section{School Community}

The Midwestern community where the democratic micro school is located has many different educational options for students 12 years and older. These include both non-secular and secular independent schools, traditional public schools, and high schools offering International Baccalaureate diplomas. This school stands out because of its adopted philosophy of democratic structure. The school is recently founded and will enter its third year of operation in the 2018-2019 school year. The structure of the organization is flat with a focus on democracy that includes all members of the school community (parents, students, educators/founders, and board members).

The school currently has two full time staff with a planned enrollment of 25 students for the 2018-2019 school year, giving it a 12:1 student: educator ratio. Each of the educators has a subject area of expertise. This enables the staff to meet the students' academic needs and interests. According to the organization website (2018), in order to 
address student interests beyond that of the staff, the location of the school is ideal. It is proximal to artist studios, museums, and other opportunities for the students to explore learning within the community. As an independent school, the school relies almost entirely on tuition for operating costs but keeps as low overhead as possible in order to maximize available funds for education expenses (Organization Website, 2018) The school does also offer need-based scholarships, but these opportunities directly affect the school's budget. This is a consideration in terms of the school's ability to accept and support family’s asking for tuition assistance.

\section{Democratic Micro School}

Micro schools typically have fewer than 150 students. Due to their small size, micro schools require less space which can drastically reduce overhead and allow for devotion of school funds to educational experiences (Darling \& Gerlenter, 2017). Further, they also use a democratic learning model, which includes the whole school community (parents, staff, students) and state standards to determine the educational path of the student body. Students in a true democratic school environment are given a significant amount of latitude in determining their own learning process (Korkmaz \& Erden, 2014; McCormick, 2017; Woods \& Woods, 2012). As an independent school intent on gaining accreditation, the school of study has a mission, an academic learning "plan," and board that would be incorporated into the school's structure. Processes and procedures have been incorporated into the structure in order to work towards the mission. Because of its small size and democratic processes, this setting provides an interesting opportunity to better understand the leadership behaviors that might be present across the school community. 
The school used for this study exemplifies the flexibility of a micro school due to its downtown location. The space occupied by the school is open with easily movable tables, chairs, and couches. The school exemplifies the "one room" approach in that there is simply a large, bright, open, and airy space where the students gather (Prothero, 2016). The space allows for full school community gatherings when needed but is also large enough for students and educators to have collaborative and individual niches when necessary.

The school has weekly meetings in which all of those in attendance (students, staff, parents, other community members) may add agenda items. Further, the students chair committees and are members of the non-profit which further enables them to make choices about their learning (Organization Website, 2018). During the weekly meetings, the school community creates and establishes the schedule and goals for the next week (Organization Website, 2018). In preparation for each meeting, a blog post with requests for agenda items is posted, and then the school community is invited to add agenda items.

\section{Organizational Analysis}

Democratic schools spread the responsibility of determining direction and goals to the whole school community (McCormick, 2017; Woods \& Woods, 2012). Even within this context, "every living system creates specialized roles to get important work done" (Bolman \& Deal, 2013, p. 49). In a learning organization, the structure of what, how, and why of the learning is often based upon national, state, or subject specific guidelines which is then supported by instruction in a classroom. The internal structure of an organization determines how decisions are made and who is involved in making the decisions (Bolman \& Deal, 2013). In a democratic school, the activity and focus of study 
are decided upon by the members of the school community (McCormick, 2017; Woods \& Woods, 2015)

In an organization, many types of coordination can exist. The focus of this study included the constructs of vertical and lateral structural coordination (Bolman \& Deal, 2013). The process of coordinating the goals and actions of the learning group are an important aspect for any organization (Bolden, 2011; Bolman \& Deal, 2013). When considering vertical coordination, the central tenet is the role of an authoritative figure in overseeing the learning processes. In larger organizations, a hierarchical structure may be more necessary (Leithwood, Mascall, Straus, Memon, \& Yashkina, 2007). In a traditional large school model, students have little or no control of the subjects and topics they are required to learn in school (Goleman \& Senge, 2014). In a laterally coordinated schooling environment, the opportunity of student choice may increase. Lateral forms of structure tend to be less rigid and are much more open to multiple avenues of feedback in process and product (Bolden, 2011; Bolman \& Deal, 2013; Kofman \& Senge, 1993;

Stephenson, 2009). In the existence of a primarily lateral structure, decisions are made in a more collaborative team-based environment (Bolden, 2011; Bolman \& Deal, 2013; Stephenson, 2009).

Key structural imperatives of the democratic micro school include "core processes, the environment, the strategy and goals, information and technology, and the nature of the work force" (Bolman \& Deal, 2013, p. 61). In this school environment, the flow of information through the use of technology can and should be incorporated into each facet of the organizational structure (Kowch, 2009).

\section{Information and Technology}


In new school models including democratic micro schools "new technologies continue to revolutionize the amount of information available and the speed at which it travels" (Bolman \& Deal, 2013, p. 64). One of the primary ways for the members of the school to address and communicate with each other is using the school website. The members have usernames and passwords which they use to update and set agendas. Further, this is directly connected to interests and curriculum as members establish times for studying topics of interest (Organization Website, 2018). All members of the school community have access to the website, as well as the ability to add or edit information on the website. It is clear there is a strong reliance on technology to communicate amongst the members of the school community. This is one way the core processes of the school are shared.

\section{Core Processes}

Core processes include at least three elements: "raw materials, inputs vs. outputs, \& beliefs about the link between inputs, activities, \& outcomes" (Bolman \& Deal, 2013, p.62). In this setting, the raw materials are the thoughts, interests, and ideas in the school community. These ideas are shared during the weekly meetings (Organization Website, 2018). The inputs are represented by the process of the idea formation, followed by the processes of school community discovery needed to direct learning. The outputs are the products, the experiences, and representation of the learning completed within in the school community. The core processes of the school used in this study followed a "democratic governance model where the school is directly run by the students, families, and teachers" (Organization Website, 2018). 
Core processes at this school may be governed by the school community, but it is communicated by the students, parents, and educators using technology (Organization Website, 2018). On the school webpage there is a list of topic links that communicate dates, times, and location for how those topics will be addressed. One such example is the identification of a poetry "unit" with the relevant description of topics and the meeting times (Organization Website, 2018). While this example was educator created, students have the opportunity to share their own ideas and are encouraged to give presentations about topics of interest. There is a structure that specifically exists to allow the students to present to the school community about a topic that interests them.

\section{Environment}

One aspect of the school that allows it to be flexible in terms of the physical environment is the size. Woods and Woods (2012) suggested that a central necessity for a holistic democracy to work is that "people want to be able to shape the environments (where) they live and work" (p. 710). With 40 or fewer students composing the student body and 4 educators, the members are able to be more fluid and flexible with how and where they work. While the school does have a physical location downtown, there are many other options such as coffee shops, museums, and galleries where the students and educators may gather. The environmental construct of the school is quite flexible. The simplicity of the school's size and structure allows for a stable environment for the members to learn (Bolman \& Deal, 2013).

\section{Strategy and Goals}

The major task of leadership in an organization is creating mission, vision, and goals. In a democratic school, the creation of the mission, vision, and goals is a school 
community process; this is an overlap of the school's overarching processes (Bolman \& Deal, 2013; McCormick, 2017; Woods \& Woods, 2012). In this school, the strategy and goals are created by the members of the school community. There are weekly meetings during which curriculum and interests are identified and then goals are created from those. Further, the educators and students work together to decide the best strategies to achieve their interests and reach set goals (Organization Website, 2018).

One important aspect of the strategy and goals is how they are shared with the community (both within the school and beyond). The school's website is open and available for access to better understand the overall mission of the school and the research that supports their mission. In addition to this, information about the weekly allschool meetings are readily available to students, educators, parents, and the public, which allows constant communication about curriculum and interests.

\section{Nature of the Work Force}

The purpose of the democratic micro school is to educate teenagers using a democratic model to allow for self-motivation, creativity, and deeper learning opportunities for the students (Organization Website, 2018). The work force in this setting is the students which can present a dilemma in being sure students are armed with the skills they need to learn with what they want to learn. This is where the educators in the school community are important in terms of being available for the students should they have questions or need help.

In the school, there is a significant amount of overlap between the structural imperatives listed above. For example, the use of technology plays a significant role in providing a platform for the core processes to be communicated. This is done on the 
school web page where topics are listed and students may find out more about a topic listed such as the time, location, and support provided in the school community to learn more about that topic (Organization Website, 2018).

\section{Leadership}

The Leader Member Exchange (LMX) Theory focuses on conceptualizing leadership as a process on the interactions between leaders and followers (Hands, 2014; Northouse, 2016; Omilion-Baker, 2017). In a democratic school, the roles of leader and follower would be expected to be more flexible than in a more hierarchical school setting. Dyadic relationships, in the case of the democratic school, would focus on the relationship between the educator and the student, the educator and the parent, and the student and the parent. In an environment like the democratic micro school in this study, one would expect the presence of four different educators with separate areas of expertise might help alleviate the innate struggle of "in group and out group" (Northouse, 2016, p.138) identified within the LMX Theory. Further, there are key principles to how different aspects of leadership might be experienced at different times by the members of the school community. In order to understand how this might look or be approached within this school, there are six facets that will be considered: communication, trust and caring, community, equity, curriculum and interests, and vision and goals.

\section{Communication}

Omilion-Hodges \& Baker (2017), asserted "that leader-member relationships are a byproduct of, and produced through, concrete and continuous communicative exchanges" (p.115). Particularly in LMX Theory, strong communication is a key element to development of strong interpersonal relationships which is the backbone of a 
democratic school community. In this school community, initial research has shown that primary paths of communication include the use of the school's website to share thoughts and ideas with the whole school and weekly meetings to create and establish processes in which all voices are meant to be heard (Organization Website, 2018).

\section{Trust and Caring}

An essential part of any democratic school environment is based on the establishment of relationships between the leaders and the members in the school community. These relationships take place between educators and students, students and students, students and educators, parents and educators, and so on (Hands, 2014). IN creating the democratic micro school in this study, the organization website (2018) stated "one of the biggest factors in keeping students engaged is their feeling of being known, appreciated, valued and accepted as an individual". The small size of the school hopes to generate and support a sense of trust and caring amongst the members.

\section{Community}

In creating their learning community, the organization website further stated "research shows that students are more motivated academically when they have a positive relationship with their teacher and feel they are part of a supportive community (Organization Website, 2018). School community relationships tend to fall primarily to the parents, teachers, and school community members who work together to establish collaborative opportunities (Hands, 2014). It is also worth noting that while a democratic school promotes choice in student learning, it also maintains that students are part of a learning community (Organization Website, 2018). The community of school provides 
an interesting opportunity to consider the experiences of the individuals invested in supporting the learning of the students and beyond.

\section{Equity}

One key aspect of the democratic learning environment is ensuring that all community members but perhaps most especially students have a voice in everything the school does (Organization Website, 2018). In addition to their belief that students should have a voice in all of the school's activities, a lengthy non-discrimination policy can be found on the web page. Further, in mentioning the importance of voice as part of democratic school, it is consistently maintained that "each student and staff member has an equal voice and vote in this expression of direct democracy" (Organization Website, 2018). Hearing and listening to members' voices is a key facet to supporting learning, promoting the school's mission, and providing the opportunities needed for the students to follow their interests but to also support the interests of the school community.

\section{Curriculum and Interests}

In considering how the school's curriculum develops the Organization Website (2018) shares the importance of students having the reflective understanding to be in charge of their own learning with a focus on the skills necessary to understand "why". The expectation is that they will ultimately develop an understanding of what they will need to master the "who, what, when, where, why, and how of learning. As shared in the weekly communication, there are many opportunities for the students to explore topics of interests. It is worth noting that while the school does support the student's right to choice in learning, the school does follow and use the curriculum guidelines created by the state's Department of Elementary and Secondary Education (DESE). The students 
develop blogs addressing their reflective learning and to also show their learning and understanding within the context of school created competencies. Students' choice in curriculum is an important aspect of the democratic school model; how they experience this will show within how thoughts and ideas are communicated and supported within the school community.

\section{Vision and Goals}

Student voice is an important aspect when establishing goals within the school community (Hands, 2014). In addressing the overall vision and goals of the school, there are weekly meetings in which "students chair committees (and) are legal members of our non-profit" (Organization Website, 2018). The students play an important role in helping determine the direction of the school. The weekly meetings and open discussions shared in the minutes support the inclusion primarily of the students and educators in determining the direction.

\section{Implications for Research in the Practitioner Setting}

The processes involved in working together to establish shared vision and set goals, create a community of caring and trust, building constructive communities, listening to the voices of others, and provide clear thoughtful communication are crucial aspects of both leadership and organizational success. The practitioner aspect of developing an understanding of how leadership is experienced by all members of a democratic school community could provide lessons for practitioners already working in democratic schools, those interested in starting a democratic school, educators in their classroom, school communities interested in the democratic micro school model, or colleges of education in their teacher training programs. 
There are many models of democratic micro schools, some more successful than others. For example, two of the most of successful democratic schools, Summerhill in England and Sudbury Valley School in the United States both meet the qualification to be democratic schools; however, their model and school structure are different (Hudson Valley, n.d.; Summerhill; n.d.). Respecting different models, the role of leaders and leadership in a democratic school is fluid. At different times, different individuals may step up to lead especially as their interest may allow for them to lead. The democratic school model has been defined in multiple schools (Sudbury and Summerhill) by many researchers (Gray, 2017; McCormick, 2017; Wallin, 2003; Woods \& Woods, 2012). In considering the multiple definitions of democratic schools and the different models that exist to support learning, there may be interest in a refined or simplified model that could allow teachers or administrators the opportunity to better understand how members of democratic micro school community experience leadership. These stories are missing from the current narratives about democratic micro schools. Practitioners may be interested in hearing those stories as they consider the model or potentially increasing democratic opportunities in their classrooms.

For those interested in potentially starting a democratic school or considering incorporating a model or unit using the model, the stories of the members of a democratic micro school are important. Those members, being surveyed and interviewed, could have voice in helping practitioners learn about democratic micro schools. Perhaps, using the components of Figure 1 to complete a pre-and-post program evaluation might help practitioners develop a more applicable model to their environment. 
In a school with a universal democratic outlook that creates an environment where all members are valued, how is leadership experienced? More importantly, what might leadership look like in this environment? Woods and Woods (2012) defined a continuum of 13 items that can be used to define a democratic school. In considering those items, along with other suggested leadership criteria, the final important quality of this research is defining what leadership looks like in a democratic school and knowing this, describe how it is experienced. Because there is so little written about this combination of models, this research could increase awareness of the opportunities that might exist outside of traditional schooling models. While democratic micro schools do exist, their presence and research about the members within those school communities seems to be published primarily on school and association websites.

Perhaps, in completing research about this school, the opportunity to share with a wider audience is the significance. What is really at stake here is the near complete removal of the traditional education models and replacing them with student ownership of their learning and encouragement to take an active role in what they learn (Wallin, 2003). Students are given the opportunity to lead their own lives and discover what leadership means to them personally as well as within a community of other individuals. As the narrative about leadership and student leadership is important, giving voice to all members of the school adds to the current understanding about applying democratic practices within a school.

\section{Summary}

The community of a democratic micro school is defined by the students, the parents, the educators, and in some cases the larger surrounding community. This study 
focused upon those members directly involved in the school: the educators, the students, and their parents. Key components for the structural organization of a democratic school include the school environment, use of information and technology, and the nature of the community support, the strategy, and goals of the school (Bolman \& Deal, 2013). There is a juxtaposition between the organizational structure and how leadership may be experienced within the school community.

One way to consider how the structure of the school supports the overall goal of the school is using the lens of the LMX Theory. The school provides a unique setting in which to consider how the members experience leadership. Using the platform of the LMX Theory in conjunction with the central themes of an organization like that of a democratic school, the following will be considered: how technology and other processes are used to communicate information, ways in which relationships between members supports trust and caring, the opportunities for equity in all voices being heard, how the individual and the community decide both the curriculum and interests and the vision and goals of the school (Hands, 2014; Hiatt-Michael, 2001; Hoerle, 2015; McCormick, 2017; Northouse, 2016; Omilion-Hodges \& Baker, 2017; Ratnavale, 2017; Woods \& Woods, 2015). The school used for this study provided an excellent backdrop to consider the experiences of the members due to its size and democratic model.

Together, juxtaposing the structural components identified by Bolman and Deal (2013) with the leadership components of a micro school which include communication, trust and caring, vision and goals, community, equity, curriculum and interests, this setting provides a different back drop from previous settings. The democratic community of this micro school is composed of parents, students, and educators. Together these 
educators work to establish an environment where learning can take place. In the process of learning, members of the school community may take on the role of leadership at different times. Leadership processes and experiences are fluid. Central to the success of this structure are communication, trust and caring, community, equity, curriculum and interests, and vision and goals. 
SECTION THREE: SCHOLARLY REVIEW 
As the United States is ushered into a potential new era of education, one significant concern is the expansion of unregulated school models (Carpenter \& Kafer, 2013; Darling-Hammond, 2017; Egalite \& Wolf, 2016). With the increase of school options for families, a significant amount of research has focused on how both for profit and not for profit charter schools have influenced the traditional public-school model (Darling-Hammond, 2017; Egalite \& Wolf, 2016; Jabbar \& Li, 2016; Loeb, Valant, \& Kasman, 2011; McShane \& Eden, 2015). The shift in the conversation about methods for increasing opportunity and choice has increasingly begun to focus on vouchers. Vouchers increase privatization of schooling and while proponents espouse choice and opportunity, opponents worry about increased inequality and inequity (Berger \& Winters, 2016; Cooper \& Randall, 2008; Darling-Hammond, 2017). This shifting climate in education privatization could increase the public scrutiny of independent schools, their models, and their potential for success.

The body of research on the private or independent education environment has been less significant. Given that this sector currently only accounts for slightly more than $10 \%$ of K-12 education in the United States (Hentschke \& Wohlstetter, 2007; McFarland, 2018), it is little wonder that the volume of academic research is smaller. Amidst growing concerns about public school performance (Berger \& Winters, 2016; Cooper \& Randall, 2008; Menashy, 2014), increasing choice and instituting new educational models have gained support (Horn, 2015; Kowch, 2009; Lapowsky, 2015; Prothero, 2016; Tanz, 2015). In recent years significant concern for student achievement and new schools operating with innovative models for education have increased in the available options in the independent school market (Barbour \& Reeves, 2009; Lapowsky, 2015; 
Prothero, 2015, 2016; Ratnavale, 2017). These models will likely strengthen the competition in the independent school market and may also, in some cases, necessarily increase supply (Hoerle, 2015; Horn, 2015; Prothero, 2015). In addition to the shifting market in independent school education, there is also a new crop of school leaders in these experimental innovation-rich environments.

In their 2017 study, Shakeel and DeAngelis found private school principals had increased decision-making options primarily due to the lack of federal, state, and district policy mandates. Leithwood, Sun, and Pollock (2017) posited that one of the key influences on school success is leadership. In fact, in their analyses, they found no documented evidence of successful school turnaround in the absence of strong leadership. As new emerging independent school models are on the rise, an interest in their leadership and structural models should also increase.

The goal of this scholarly review is to consider the current political movement towards educational privatization and describe the emergence of different schooling models as part of this movement. With this focus, special attention will be given to detail the history and structure of the democratic school movement as one of these models, the rise of the micro school as a platform for the democratic school philosophy, student engagement, and current leadership models that might be applied in a democratic micro school.

\section{Privatization and Independent Schools}

School choice options have increased significantly since the early 1990's (Butler et al., 2013; Carpenter \& Kafer, 2012). Egalite and Wolf (2016) defined "private school choice program as any government initiative that provides a substantial amount of up- 
front financial assistance for parents to enroll a child in a private school” (p. 442).

Privatization acts to increase parent choice in school for their children. The increase in school choice options for families follows the market perspective that "competitive pressure" will positively impact school development (Butler et al., 2013; Loeb, et al., 2011, p. 145). Further, the increase in school voucher programs would further increase demand for increasing the number of choices. The Federation for Children (n.d.) reported 26 states with private school choice programs. This is an increase from the nine programs reported by Loeb et al. in 2011. As demand for programs has increased, landscape of schooling options in the United States is also shifting.

The focus of school models for this research will be on those schools that operate outside of the context of district, state, and federal legislative control (Butler et al, 2013; Carpenter \& Kafer, 2012) The types of schools that fit into this context include traditional independent schools, new or innovating independent schools, and extra-district charter schools (Butler et al.; Cooper \& Randall; 2008; Egalite \& Wolf, 2016; Hoerle, 2015; McShane, 2015). Figure 2, shows and describes five innovating models operating today. Some of the schools shared are independent schools, others are charter schools.

For this research, independent schools will be those that are considered non-profit and which do not receive public funds (National Association of Independent Schools, n.d.; Schuermann \& McGovern, 2016). Traditionally, these schools have been referred to as private schools due to their tuition requirements. For many, the primary revenue stream for the school is derived from tuition (Farber, 2012). Schools that operate on the independent model also have their own board driven mission. Emerging independent schools are those that subscribe to newer educational models (Horn, 2015; Prothero, 
2016; Tanz, 2015). Charter schools that receive public funds but are managed by profit educational agencies tend to also operate outside of district control (Cooper \& Randall, 2008; Loeb et al., 2011). These schools have the ability to test and refine models that could potentially help public education move forward.

According to the McFarland et al. (2018) in 2016, 17.2\% of the United States' school aged children were enrolled in independent and public charter schools. Over the past 15 years independent school enrollment has varied between $9.6 \%$ and $11.7 \%$ (McFarland, 2018). While the number of enrolled students has been consistent, the demand for creating innovative academic opportunities in both charter and independent schools for the 21 st century learners is increasing. To address the interest in innovative academic opportunities, Hoerle (2015) identified a significant increase in the number of alternative educational models available to families. Features of these schools can include academically rigorous curriculum, deeper learning, personalized learning, online curriculum, and home schooling (Hoerle, 2015). Each of these models incorporates aspects that would be considered innovative by Online Education Symposium for Independent Schools (OESIS). Further, if they have not already done so, they have the potential to shift traditional education models in both public and independent schooling.

The programming movements described in the OESIS report are supported in a variety of ways by the sample institutions in Figure 2. The emerging models identified included interdisciplinary approaches, competency based, online and blended learning, problem-based learning, focus on science technology, engineering, and mathematics sometimes with the addition of arts, emphasis on computer science and coding, entrepreneurship, maker-based, and design thinking (Ratnavale, 2017). One aspect 
missing from these models, but perhaps assumed, is that there has a been a significant increase in the use of technology in these emerging environments (Horn, 2015; Prothero, 2015; Tanz, 2015).

\begin{tabular}{|c|c|c|c|}
\hline $\begin{array}{l}\text { Learning } \\
\text { Model }\end{array}$ & Example School Mission & $\begin{array}{l}\text { Example } \\
\text { school } \\
\text { Year Founded } \\
\text { Location(s) }\end{array}$ & $\begin{array}{l}\text { Funding } \\
\text { Model }\end{array}$ \\
\hline $\begin{array}{l}\text { Academically } \\
\text { Rigorous } \\
\text { Curriculum }\end{array}$ & $\begin{array}{l}\text { Innovation is the cornerstone of } \\
\text { student growth and discovery leads } \\
\text { to innovation. A challenging } \\
\text { academic curriculum engages and } \\
\text { encourages students to become } \\
\text { lifelong learners. }\end{array}$ & $\begin{array}{l}\text { BASIS } \\
1998 \\
\text { Arizona, } \\
\text { Texas, and } \\
\text { Washington, } \\
\text { DC }\end{array}$ & $\begin{array}{l}\text { Publicly } \\
\text { funded } \\
\text { charter } \\
\text { school } \\
\text { managed by } \\
\text { for profit } \\
\text { company }\end{array}$ \\
\hline $\begin{array}{l}\text { Deeper } \\
\text { Learning }\end{array}$ & $\begin{array}{l}\text { Use four connected principles to set } \\
\text { aspirational goals and create a } \\
\text { foundation for understanding: } \\
\text { equity, personalization, authentic } \\
\text { work, collaborative design }\end{array}$ & $\begin{array}{l}\text { High Tech } \\
\text { High } \\
2000 \\
\text { San Diego, } \\
\text { CA }\end{array}$ & $\begin{array}{l}\text { Publically } \\
\text { funded with } \\
\text { attached } \\
\text { professional } \\
\text { development } \\
\text { school }\end{array}$ \\
\hline $\begin{array}{l}\text { Personalized } \\
\text { Learning/ } \\
\text { Micro School }\end{array}$ & $\begin{array}{l}\text { Enable all children to reach their } \\
\text { potential using small class sizes and } \\
\text { innovative technology platform to } \\
\text { encourage student choice and } \\
\text { teacher supported learning goals. } \\
\text { Students are able to manage and } \\
\text { assess their own learning progress. }\end{array}$ & Alt School & $\begin{array}{l}\text { Tuition with } \\
\text { significant } \\
\text { outside } \\
\text { investment. }\end{array}$ \\
\hline Cyberschool & $\begin{array}{l}\text { Inspiring academically talented } \\
\text { students to academic and life } \\
\text { success. }\end{array}$ & $\begin{array}{l}\text { Stanford } \\
\text { Online High } \\
\text { School }\end{array}$ & Tuition \\
\hline $\begin{array}{l}\text { Homeschool/ } \\
\text { Unschooling }\end{array}$ & $\begin{array}{l}\text { Parent or student directed learning } \\
\text { usually supporting a philosophical } \\
\text { point of view or concern about local } \\
\text { school options. }\end{array}$ & $\begin{array}{l}\text { Households all } \\
\text { over the US. }\end{array}$ & $\begin{array}{l}\text { Family } \\
\text { funded }\end{array}$ \\
\hline
\end{tabular}

Figure 1: New Learning Models as Alternatives to Traditional Public and Independent Schools. This figure provides an overview of emerging educational models. There are many examples that could have been given, however, the choice for those shared were 
developed from Hoerle's 2015 report. The 2017 Innovation Report published by OESIS provided key instructional principles that could be identified as emerging.

Not surprisingly, most of the learning models shared in Figure 2 have a heavy focus on technology. Currently, the bulk of the literature about emerging schools focuses on the founders and the instructional models (Horn, 2015; Lapowsky, 2015; Tanz 2015). For example, Mark Zuckerburg, founder of the social media giant, Facebook, has shifted his educational philanthropy to help fund the Alt School (Tanz, 2015). In addition to this, Sal Khan, the founder of Khan Academy, used the backing of his board and some of California's tech elite families founded the Khan Lab School (Tanz, 2015). These new schools represent the more well-known or well publicized of these new models.

However, there are opportunities to adapt and create new schools by merging models and maintaining a much smaller scale of size. Strike (2008) noted small schools are often schools of choice so within the larger context of the movement towards privatization, competition, and new models, those with a strong interest in education are creating new and different schools that provide different opportunities than traditional models. The strength of the democratic schools as an opportunity for the personalization of deeper learning opportunities provides a strong back drop for how leadership may be experienced by the members of the school's community.

\section{Democratic Schools}

Dewey (1916/2008) shed considerable light on the role that education plays in establishing a democratic based society. Allowing students the right to selfdetermination within the larger context of the community is an important part of educating for a democratic society. The original democratic or free school was founded in 1921, to provide a significantly different learning opportunity in England during a time 
in which children's rights were non-existent (Summerhill Overview, n.d.). The democratic school model usually referred to as free schools arrived in the United States in the 1968 with the founding of the Hudson Valley Sudbury School on the East Coast (Hudson Valley, n.d.). Both Summerhill, Sudbury Valley, and many schools since have been founded on the philosophy that children, given a rich educational environment, opportunities to explore the world, and the right to follow their interests, will build the necessary traits and skills needed to be adults (Gray, 2017; Korkmaz \& Erden, 2014; Woods \& Woods, 2012). Given the nearly 100 year history of democratic minded education, the abundance of research about these schools remains small. The next sections will focus on the characteristics of democratic schools, democratic schools with the micro school movement, the potential for student engagement in democratic schools, and the role of leadership in a democratic school.

\section{Characteristics of Democratic Schools}

In their study of characteristics of democratic schools, Korkmaz and Erden (2014) identified 808 items that helped define democratic schools. Woods and Woods (2012) identified holistic democracy as one that gives individuals the chance to grow in all facets of their existence as well as one where all influencing decisions are school community based. As part of their research, they identified a conceptual framework that included 13 variables differentiating between "rational bureaucratic hierarchy and holistic democracy" (p. 714). Hope (2012) described democratic schools as those that called for full community participation in all areas of the school from physical plant decisions, to curriculum, to school vision and goals. Gray (2017), whose primary case of research has been Hudson Valley Sudbury School, noticed the importance of age mixing as well as 
significant opportunities for student led learning in the school. In considering the research about democratic schools' characteristics, themes emerge which include participative, age mixing, personalized learning, and a focus on both individual and communal growth.

Community. Kofman and Senge (1993) asserted that the existence of oneself within the community is "a narrative striving to connect with other narratives to become richer" (p. 14). In the democratic school, the community is at the heart of the learning. The members both work together and independently to construct opportunities for learning (Bradley-Levine \& Mosier, 2017; Korkmaz \& Erden, 2014; Woods \& Woods, 2012). The importance of community in a democratic community is underscored by the necessity of the individuals to work together to complete tasks necessary for community success. These tasks not only include curriculum, interests, and learning but perhaps most importantly the establishment of rules and protocol within which the community will function (Gray, 2017; Korkmaz \& Erden, 2014). In order for a democratic school to function properly, all members of the community must be participative.

Participative. Democratic schools are based upon the key idea that all members of the community participate in decision making that affects the whole school community. At the Hudson Valley Sudbury School, Gray and Chanoff (1986) observed that the school community has several ways in which students participate in the school community, the first being community meetings, the second being a part of the school justice committee. Together, these two bodies provide a significant amount of governance for the school. Student ownership in both decisions impacting their learning and those impacting the whole school are a key part of the democratic school model 
(Gray, 2017; Gray \& Chanoff, 1986; Hope, 2012; Kormaz \& Erden, 2014; Woods \& Woods, 2012).

Age mixing. Gray and Chanoff (1986) recognized the role age mixing in giving younger students the opportunity to interact and learn from their older peers. Perhaps, the most significant aspect identified is the opportunities that age mixing allowed for younger students to learn from older students.

Personalized learning. Bradley-Levine \& Mosier (2017), Gray (2017), and Wood and Woods (2012) addressed the importance of providing a school community rich with learning opportunities to support student and community interests on a large scale. Alshurman (2015) found a key tenet to democratic education is the opportunity for individual pursuit of knowledge while also balancing and acknowledging the needs of others. The ability to do this connects with the personalized learning described by Hoerle (2015). Personalized learning opportunities require a significant amount of support without judgement from adults within the learning the community (Alshurman, 2015; Gray, 2017). Democratic schools provide many opportunities for personal growth of the students (Korkmaz and Erden, 2014). Democratic schools promote personal learning by giving students the support and tools they need to grow as learners both within and beyond the school community. Personalized learning presents increased challenges in a larger school community which encourages these types of learning environments to operate within the construct of the smaller environment and student population.

\section{Micro Schools}

The Micro School Movement in the United States began in 2000s with the use of a one room, technology based, blended learning opportunity (Horn, 2015; Prothero, 
2016). Examples of these early models included Quantum Camp founded in 2009 and Acton Academy also founded in 2009, both with the focus on small size with student populations ranging from 12-75 students (Horn, 2015). The small size of the micro schools enables these environments to increase the flexibility of curriculum and instructional design, which leads to increased opportunities for personalized learning (Horn, 2015; Prothero, 2016). The literature using the term micro school is pretty small; however, based on the articles written by Horn (2015) and Prothero (2016), the typical micro school student population is fewer than 150 students.

\section{Engagement in Democratic Schools}

Flannagan (2015) asserted that "when teens have a valued member of their local communities with the prerogatives associated with the membership, they learn that they have a stake in democracy" (p. 72). Further, Flannagan stated that the "very word community means building something with others" (2015, p. 71). The newly founded democratic school would have to focus on the creation of a new educational organization with extreme importance being placed on student participation in the process. To get young people engaged, the social interactions with the teachers and their peers are a crucial drive for attendance (Cooper, 2014). The personal connections can act as a driver to encourage students to continue to attend and participate within the school community. Martin and Dowson (2009) stated there is a strong importance for educators to use relational connections increase to the engagement of students in the learning activities.

In a democratic micro school community, the importance of establishing and building relationships addressing the whole student further helps to solidify their engagement to their own learning as well as others' learning. Martin \& Dawson (2009) 
and Cooper (2014) underscored the importance of connective instruction in relationship building between students, the material, their classmates, and the teachers. In this type of connected environment, student engagement is increased, and the community is working and learning together.

\section{Leadership in Democratic Schools}

Leadership in democratic schools is flexible with members of the community stepping into leadership roles when necessary, but also being followers when needed. Democratic Leadership (Hope, 2012; Woods, 2002) System of governance is important; students and faculty work together to establish rules and support for students to follow the rules (Gray, 2017; Korkmaz \& Erden, 2012; Woods \& Woods, 2012). A key component to the success of democratic schools is the use of meetings to generate decisions (Gray \& Chanoff, 1986). Answering to the questions about who leads the school in a democratic school, Hope (2012) suggested that the community leads the school. The fluidity of leadership and follower roles within the context of the democratic school community draws upon many different types of observable leadership models. The multitude of models that could provide a thoughtful framework for leadership in a democratic micro school include: Leader Member Exchange, Collaborative Leadership, Distributed Leadership, Authentic Leadership, Adaptive Leadership and Servant Leadership.

\section{Leader Member Exchange Theory}

Hope (2012) considered how a sense of belonginess impacted the experience of students at a democratic school. This sense can be further defined by both relationships between leaders and followers, particularly as it pertains to the fluidity of these roles in a 
democratic school. Organizations such has schools, might have "in groups and out groups" where a different relationship exists between the leader and followers (Northouse, 2016). In a democratic school, the formation and/or existence of these groups may be strongly influenced by the importance of participation amongst all school community members.

Graen and Uhl-Bien (1995) conceptualized the Leader-Member Exchange (LMX) by using a three-domain approach. One key factor to the domain approach included the addition of relationships to the model. In a fluid, participative environment such as a democratic school, the relationships of the members are important. In considering relationship-based leadership, Graen \& Uhl-Bien (1995), maintained that trust, respect, and mutual obligation built strong relationships and supported different needs between the leaders and the followers. The community based participative nature of democratic school would require the members establish strong relationships and trust in order to assume the role of follower or leader when necessary.

The focus on relationships between leaders and followers is a central tenet to the LMX Theory (Graen \& Uhl-Bien, 1995; Northouse, 2016). The application of this theory acknowledges the importance of establishing strong relationships within an organization in order to advance the vision of the organization. The democratic school environment is one where all of members participate to establish the vision and to move it forward. The importance of relationships is also vitally important to the collaborative leadership model described by Hope (2012). 


\section{Collaborative Leadership}

The territory of collaborative leadership is murky as there are many other leadership theories that could qualify including distributed leadership and team leadership. There are central principles to each of these that would support participative environment of a democratic school. Northouse (2016) described team leadership as a form of leadership that is process oriented. Levi (2014) supported with the idea that teams form for a purpose, they work to achieve that purpose, once the purpose is achieved, then the team disbands. This idea fits into the fluid leadership within a democratic school as there will be times when certain individuals assume a leadership role to achieve a goal; once that goal is achieved, then members move onto other opportunities where they may be a leader, or they may be follower. A key facet to this type of leadership is trust and cohesion (Northouse, 2016).

\section{Distributed leadership}

A central tenet to the democratic schooling model is the theme of shared leadership. Essential school community decisions do not rest in the hands of one single individual but rather across the thoughts and ideas of many. Distributed leadership may also provide a lens to view the nature of leadership in a democratic school. Devilliers and Pretorius (2011) described distributed leadership as a network of interacting individuals where there are open boundaries and opportunities for leadership. Harris (2013) described "two key components, distributed tasks and distributed influence on process" (p. 546). Spillane, Halverson, \& Diamond (2001) maintained practice distributed over leaders, followers, their situations, and that incorporates the activities of multiple groups of individuals provides a strong framework for understanding distributed 
leadership. "The social context and the inter-relationships therein, is an integral part of the leadership activity" (Leithwood et. al., 2007, p. 339). In a democratic school, the tasks could be described as learning processes, day-to-day maintenance of the academic space, and many of the other requirements necessary for a school to exist. Leadership in the tasks falls to those with interest in those tasks.

Further, a key component of distributed leadership is the formation of relationships within the community (Harris, 2013). Students have to feel connected with their teachers in order to trust the processes of learning (Flannigan, 2015; Harris, 2013). The importance of day-to-day interactions underscores the central principles to the distributed leadership model, that decisions are made amongst the members of the organization (Harris, 2013). The ideals of distributed leadership as exemplified in a democratic school are in parallel with the goals and processes. Distributed leadership has been viewed as a type of leadership to move towards organizational change, which clearly connects with idea of democratic education (Harris, 2013).

In the age of school reform and change, success stories of distributed leadership support it as a strong model for school success. One key facet to the success of the distributed leadership focuses on the need for those filling leadership roles to have the skills and abilities necessary to successfully lead (Harris, 2013; Leithwood, 2007). Building quality and capability are key facet to the success of the distributed leadership model. In a democratic school, where the decision making is consensus-based, building leadership capability and capacity may be a crucial requirement for success. Harris (2013) also mentioned the importance of relational "relational trust" (p.552). Individuals working within a distributed leadership climate have to be able to build relationships and 
trust among the community members whose existence will be influenced by the decisions.

In a democratic school, where the decision making is consensus based, building leadership capability and capacity may be a crucial requirement for success. The process of distributing leadership responsibilities to the community would require the members to build strong relationships and to trust those making the decisions relative to specific tasks and purposes. It can be said that a democratic school could be a broader model for distributed leadership as currently the bulk of the research has focused on the tasks and responsibilities of those who are already in typical positions of leadership, principals and teachers. In a democratic school, all members of the community (especially the students) are part of making important decisions relative to the schools' daily functions.

\section{Authentic leadership}

Northouse (2016) characterized authentic leadership as that which includes “purpose, values, heart, self-discipline, and relationships" (p.198). Authentic leadership conspires to consider some aspects in the leader member exchange theory as it allows for the focus on self and then beyond self by including the importance of relationships with others (Duignan, 2014). The concept and parameters of authentic leadership fit neatly into the concept of the democratic Micro School. In an environment where students and educators work together to lead for learning, a deep understanding of self helps support building relationships within the school community. George, Sims, McLean, and Mayer (2007), further supported this in acknowledging that authentic leadership grows out of self-discovery and personal realization in finding and staying true to your values and beliefs. 


\section{Adaptive leadership}

Another type of leadership that could be identified in a democratic school would be adaptive leadership. Northouse (2016) described adaptive leadership as one where the leader is imperative to protect the followers. In this situation, the community works together to adapt to the changes experienced by the organization. Northouse (2016) and Heiffetz, Grashow, and Linsky (2009) saw the leader as someone who plays a critical role in bringing individuals together to meet challenges or bring about change. While the overall leadership structure of a democratic micro school is flat, it is important to acknowledge that the adults in the room have the responsibility to encourage and enable the young people to address challenges and work together to find solutions. The central tenet to this theory is that tensions will cause a need for a change or shift within the systems; perhaps, recognized by the leader, it is important the leadership supports and focuses energy upon the followers (Heiffetz et al., 2009; Northouse, 2016; Uhl-Bien, Marion, \& McKelvey, 2007). The students and faculty in a newly founded school, with a different social imperative, could be considered all adaptive leaders as they established a new environment within which all can learn and progress outside of the traditional accepted school structure.

Adaptive leadership arises when change is seen as a need within a social system such as a school (Heiffetz \& Laurie, 1997/2011). The concern about student engagement and motivation is a concern for those beyond the education community. Establishing classrooms and schools that support the increased engagement of students, parents, educators, and the community beyond in the education discussion is a significant part of the work of a democratic micro school. Whether founding a new school or shifting the 
culture within a school, the adaptive leadership model supports the process of this sort of shift (Heiffetz et al., 2009, Northouse, 2016; Uhl-Bien, Marion, \& McKelvey, 2007).

\section{Servant leadership}

The central component of servant leadership is that the leader always places the follower ahead of themselves (Gandolfi \& Stone, 2018; Northouse, 2016). This type of leadership especially manifests in a way that it is the leader's responsibility to meet the needs of their followers in whatever fashion is required. In a defining and true democratic school community, Hiatt-Michael (2001) stated that a servant leader was a central component. In a democratic community, there may be a time when each of the members is expected to act in a way that more clearly supports the other community members (Hiatt-Michael, 2001; Gandolfi \& Stone, 2018; Northouse, 2016). Further, another behavior of a servant leader would be to ensure equity within a community, being most concerned with those members who are the quietest, under represented, or who are on the outside of the norm (Northouse, 2016). The role of equity is a central principle in a democratic school. As with the other theories presented, the presence of opportunities of servant leadership could likely arise in a democratic micro school environment.

\section{Summary}

Within the larger context of the potential of school privatization and increase in both privately and publicly funded choice options, the democratic micro school provides a setting within which to consider school models and experiences of leadership. The school model, the focus of this research, is a democratic micro school. Important qualities of the democratic micro school are diminished size (fewer than 150 students), a

participative focus on school governance in which all community members are invited to 
be a part, a focus on the school community, and opportunities for members of different ages to work and learn together and from each other (Gray, 2017; Korkmaz \& Erden; 2014; Woods \& Woods, 2012). This environment also provides fluid opportunities for leadership for all members of the school community.

The focus on leadership in democratic schools has been primarily that of collaborative leadership where the whole school community works together to make decisions influencing individuals and the school community as a whole. One key influencer of collaborative leadership is how members establish trust and relationships with each other. The LMX Theory provides a potential backdrop within which to understand how members of a community interact with each other in moments as leaders or moments as followers. Because of the fluidity of leadership within in a democratic school, it would be expected that at times individuals take on leadership opportunities and at times they adopt the role as a follower. The LMX Theory provides a construct within which to consider the dyadic relationships between the community members (Northouse, 2016).

This use of the LMX theory does not discount the other types of leadership that could emerge in a democratic micro school. The typically flat structure of a democratic school allows for multiple forms of leadership to emerge as required by different situations. Further, some members of the community may have other more inherent leadership characteristics which further speak to the potential appearance and definition of leadership within the community of several different leadership theories.

The potential movement of privatization and increased interest in changing the current schooling paradigm provides a strong backdrop to consider different schooling 
models. Independent schools are able to operate without the mandates of state and federal government. This enables them to have a more creative curriculum which increases opportunity for personalized learning within a school construct like a democratic micro school. The democratic micro school provides opportunity for participative membership of all individuals within the community. This creates an expectation that community members experience opportunities of leadership and opportunities of followers. Together, this provides a basis for students to explore their interests and engage within the community to learn. 
SECTION FOUR: CONTRIBUTION TO PRACTICE

To be Presented as a Webinar 
Information for Ed Webinar Application

First Name: Tara

Last Name: Bonebrake

Job Title: Science Instructor

Institution: Greenwood Laboratory School

Location: Springfield, MO

Email: Tbonebrake@missouristate.edu

Phone: (417)836-3222

Twitter:@TJBonebrake and @MsBonebrake

Webinar Topic: Democratic Micro Schools- A Case Study Including History and

Process

Intended Audience: Educators and leaders interested in democratic schools and micro schools

\section{Webinar Description:}

The goal of the presentation would be to share one model of a democratic micro school juxtaposed with the other democratic models that exist within the United States and around the world. Schools centered on democratic principles are not necessarily new models, as the earliest date back to the early 1900s. The first democratic school formed in England as a conscientious objection to the traditional school models of that era. In the 1960's, Sudbury Valley School was founded, and this was the first democratic school in the United States.

A central component of the case study was the right of the students to determine their own learning path within the larger context of the democratic micro school. Six key 
democratic principles emerged through the course of research. These include the following that helped determine the relationships between community members: trust and caring, community, communication, curriculum and interest, equity, and vision and goals. Individuals who attend this webinar will have the opportunity to increase their understanding of democratic and micro school models. Practical applications could include using the principles and leadership theory shared to provide increased guidance in setting up a democratic classroom, school, program, etc. The presentation will consist of an introduction to the democratic school model, principles used in the course of the research and share the experiences of those stakeholders who participated in research. Biography: Tara Bonebrake is a science instructor at Greenwood Lab School on the campus of Missouri State University. 
Proposed Slides for Webinar (Subject to Change)
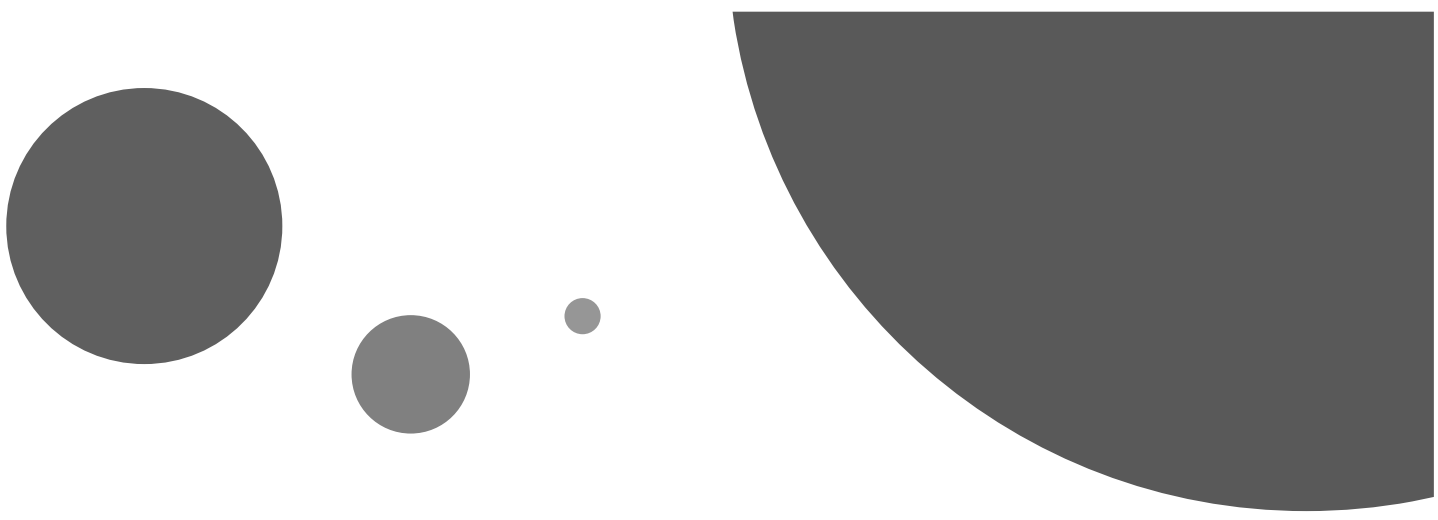

A mixed methodological case study of how members of a democratic micro school experience leadership and democratic

By: Tara J. Bonebrake, EdD.

$$
\text { principles }
$$

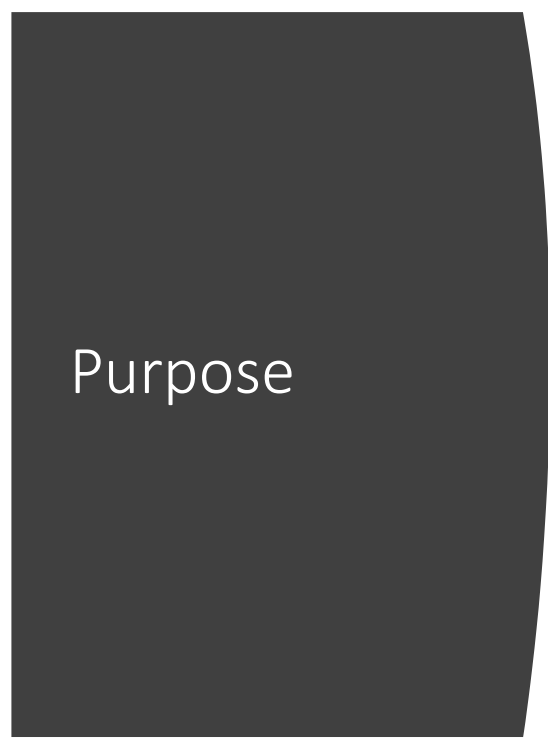

Provide Definitions and descriptions of

micro schools and democratic schools

Examples of these types of schools

Case study of one school

Where to now? 

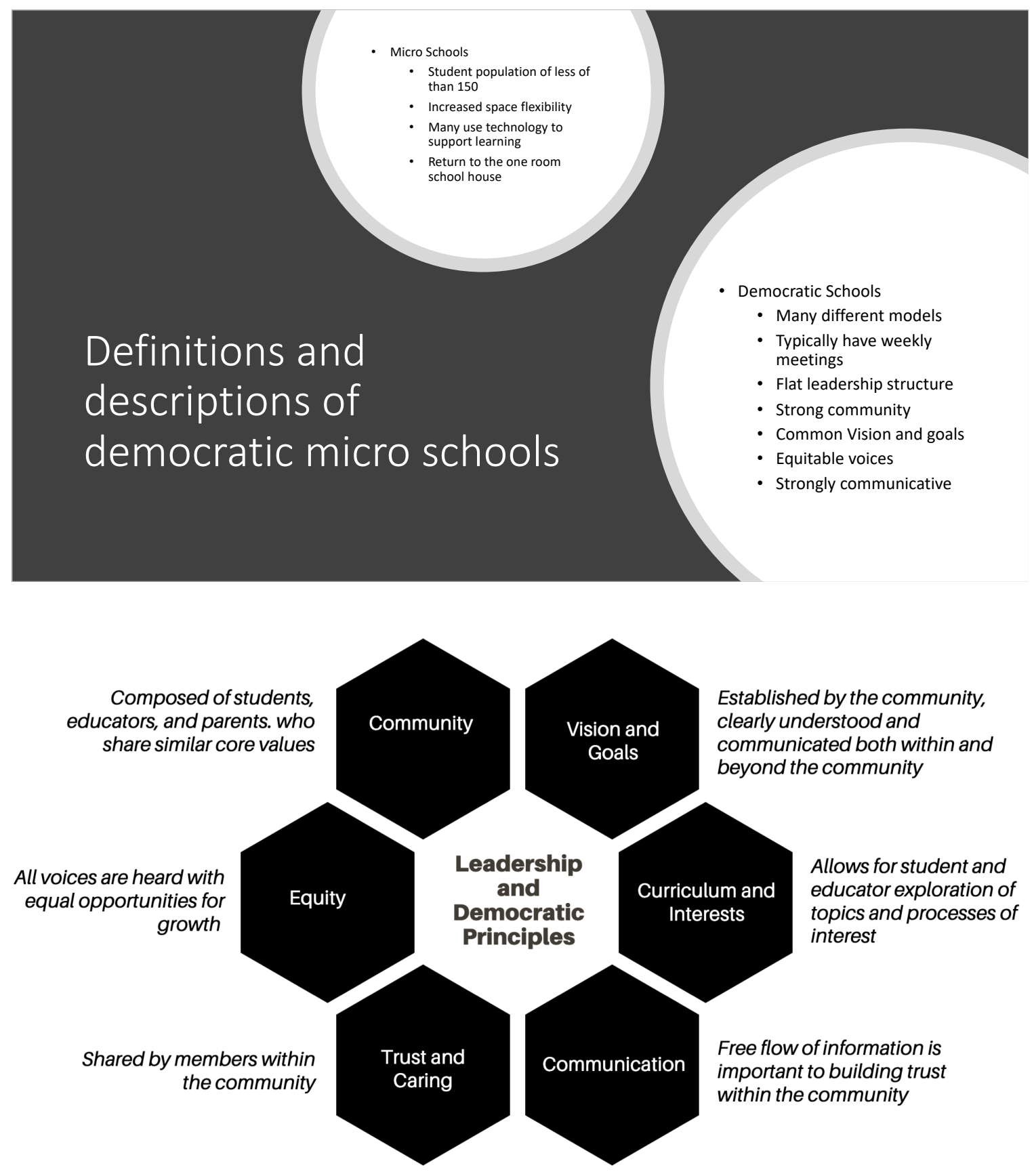
Democratic Micro Schools: History

\section{Summerhill School}

\section{The Originals}

- Summer Hill School

- Hudson Valley Sudbury School

\section{The New Generation}

- Acton Academy

- Khan Lab School

- Alt School

- many others

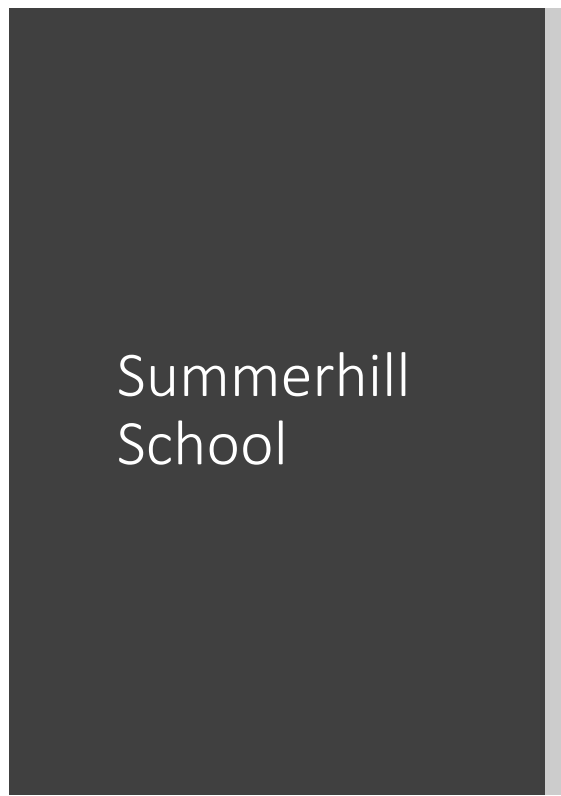

Gave students an

increase in choice

of learnig and

schools in England
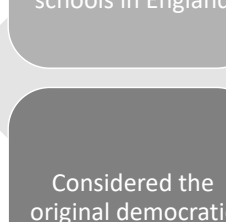

original democratic school

\section{living.}

Modified

democracy (there

is still a form of

power structure

but it still differs

considerably from

traditional. 


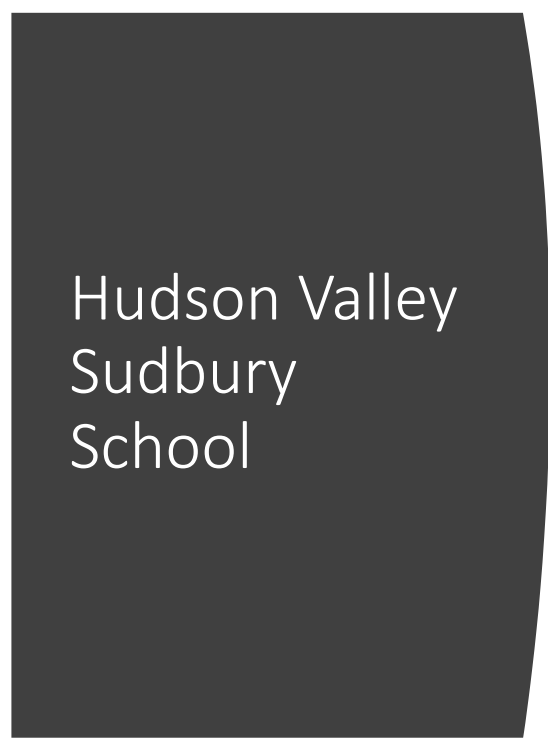

Founded in the 1960's

Too big to be a micro school

Whole community decision making process exemplifies the democratic model.

Most discussed in academic literature
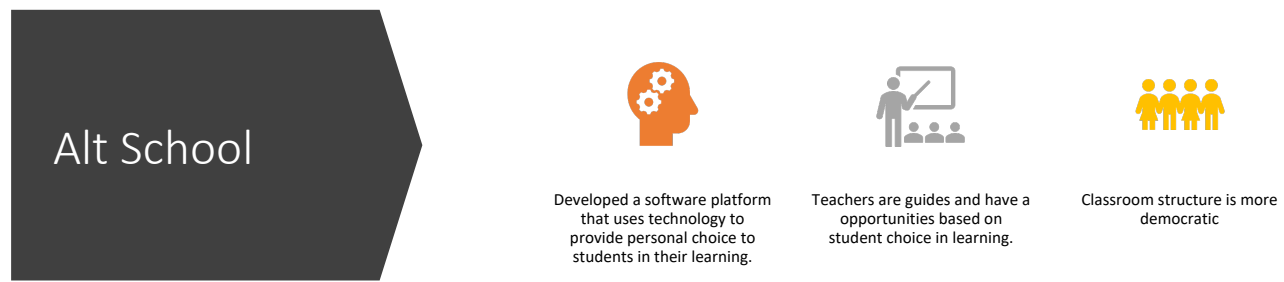

$$
\approx
$$

School structure tends towards more traditional

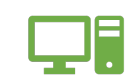

Micro school allows for 


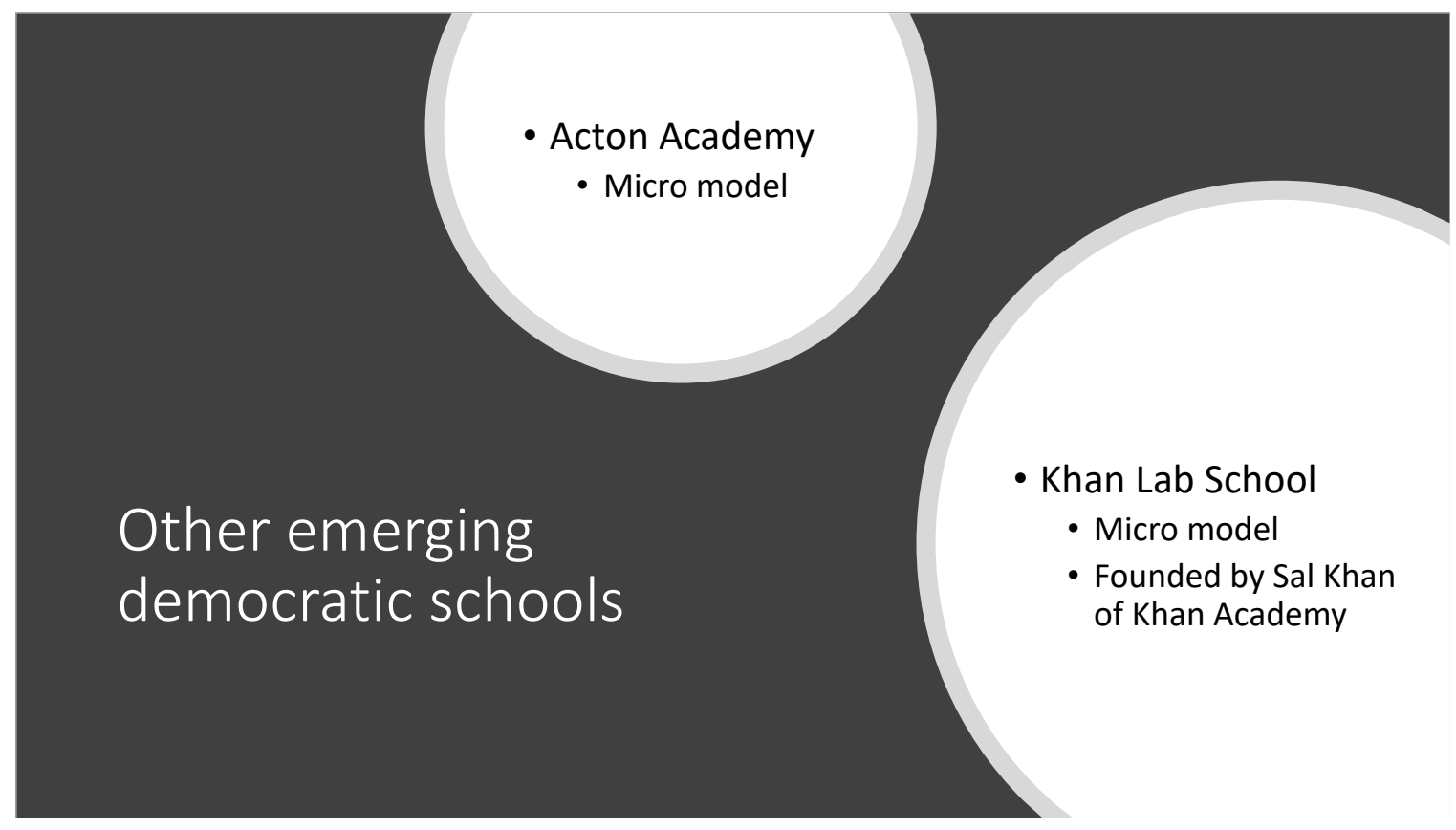

Fewer than 40 students

Privately Funded

Description of the case

May have a learning curriculum based on state standards but is not beholden to the standards.

Founded within the last five years 


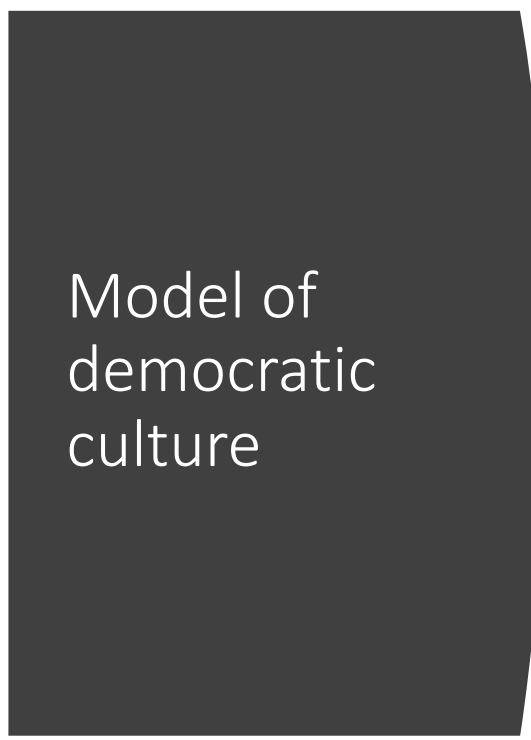

Community meetings (Weekly)

- All community members are able to add agenda items

Each day begins with a gathering

- provides the platform for sharing the learning opportunities taking place through out the day.

\section{Committees}

- Composed of students, educators and in some cases members outside of the direct school community

- judicial

- community magazine

- etc.

Many students embrace the learning opportunities presented

\section{Findings}

\section{Leadership exists on \\ many levels \\ self}

Relationships are crucial in a democratic school environment

The challenge of self-interest and democratic responsibility 

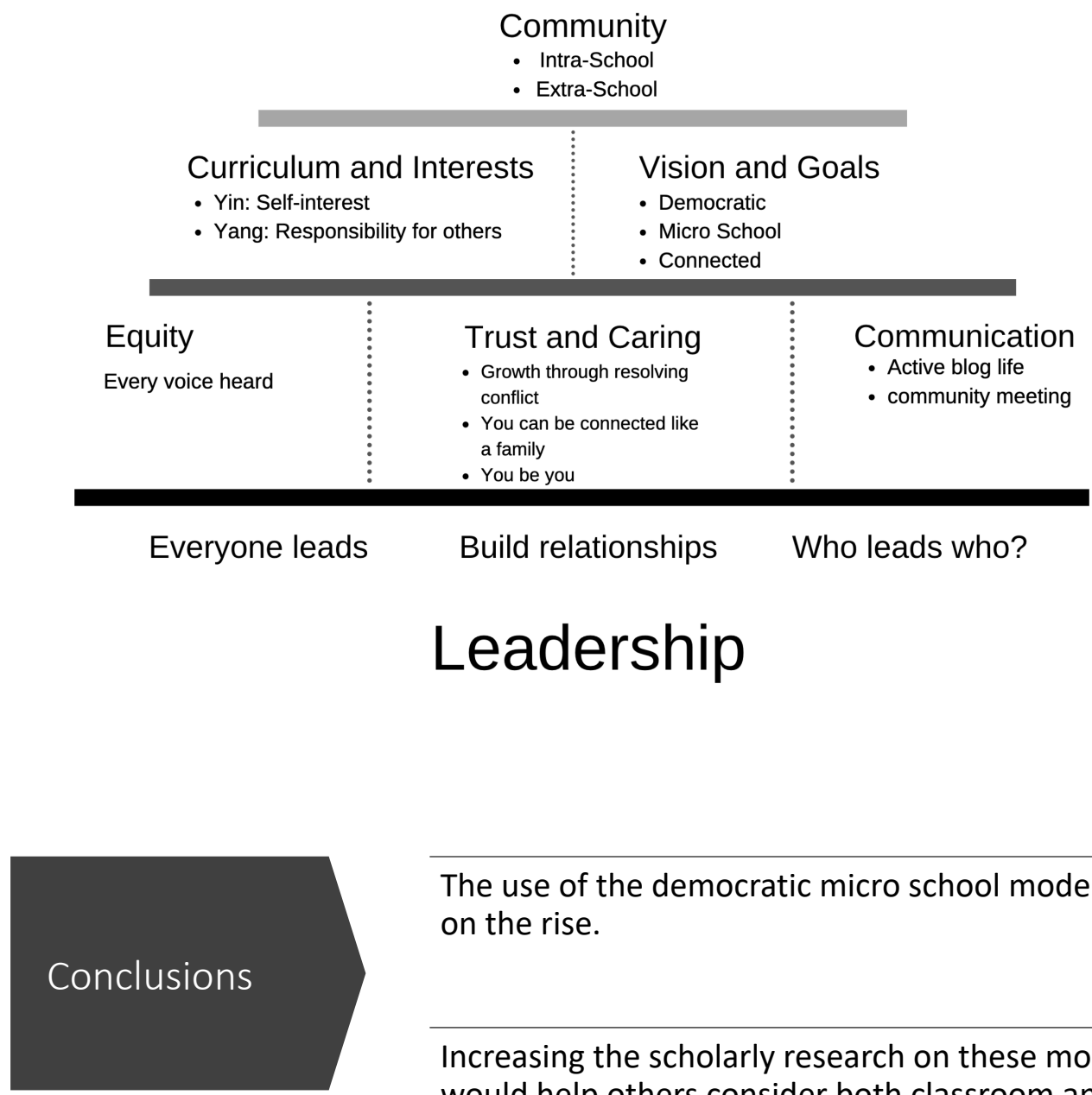

The use of the democratic micro school model is on the rise.

Increasing the scholarly research on these models would help others consider both classroom and whole school approach to the model.

One limitation to this study was the focus on a single case. 
SECTION FIVE: CONTRIBUTION TO SCHOLARSHIP

To be submitted to: School Community Journal 
Community Members' Experiences of Leadership and

Democratic Principles in a Democratic Micro School 


\begin{abstract}
Public dissatisfaction with the current public-school model has led to an increase of school opportunities such as the democratic micro school. A democratic micro school is a school with fewer than 150 students that ascribes to a democratic leadership structure where all of the school community members, especially the students, have leadership in their learning. The purpose of this study was to develop a better understanding of the lived experiences of the members of a democratic micro school community, especially regarding leadership and democratic principles. The primary researcher used a mixedmethod design with an embedded phenomenological case study to analyze a single democratic micro school. All primary stakeholders in the school community were subjects of this study which included the students, parents, and educators. The data collection process included a survey, focus groups, interviews, observations, and other school artifacts. Using six democratic principles and the LMX theory, this study to added to the literature by addressing the experiences of those individuals attending independent schools. Achieving democracy in school allows students and teachers to have control of their learning experiences. This study supported the importance of communication and trust and caring as the educational foundation upon which equity, curriculum and interests, vision and goals, and community relied. Future research could expand the understanding of democratic micro schools beyond the single case used in this study. Keywords: democratic school, micro school, independent school, community experience, school leadership
\end{abstract}


Community Members' Experiences of Leadership and

Democratic Principles in a Democratic Micro School

Traditional independent school models in the United States could be defined as mission driven, board-supported institutions having a history generally longer than 10 years (Dronkers \& Roberts, 2008; National Association of Independent Schools, n.d.; Schuermann \& McGovern, 2016). Of increasing interest are the number of new independent schools around the country, fewer than 10 years old, that are testing the traditional model paradigm. Hoerle (2015) identified four trends that did not fit into the traditional independent school experience. The trends identified included schools focused on academic rigor, personal learning, deeper learning, and an online focus (Hoerle, 2015). The complexity of traditional independent schools and challenges in changing well-established culture may allow for smaller, newer, and more fluid democratic micro schools to gain significant market share.

The micro school demonstrates the ability to blend different instructional design and pedagogy (Horn, 2015; Prothero, 2016). The size of the micro school (fewer than 150 students) makes it a unique environment to study different pedagogies. While the democratic school model is not a new model, a resurgence of interest in this model provides a strong platform for the explorations and experiences described by Hoerle (2015) and Ratnavale (2017). Combining the fluidity and flexibility of a micro school with a focus on a democratic learning model has the potential to increase student interest and engagement in learning and also increase parent interest (DiPerna \& Catt, 2016). The school used in this study, a democratic micro school, may use several different pedagogies to establish an academically rigorous environment, however, personal and deeper learning models seem to be the most prevalent (Hoerle, 2015; Ratnavale, 2017). 


\section{Leadership}

Leadership is the role of an individual to influence, support, and encourage a group to work towards a common goal (Bush, 2011; Goleman, 1996/2011; Levi, 2014; Northouse, 2016). In the democratic micro school environment, new leaders are emerging from a variety of different settings. Some of these leaders are from giant tech companies while others are teachers and school leaders who want to create a different type of school. As new schools come into existence such as the democratic micro school, it is important to increase an understanding how the members of a democratic micro school community experience leadership.

Acknowledging that school leadership influences the successful outcome of students, increasing the body of academic knowledge about these democratic micro school environments is imperative (Bush \& Glover, 2014; Leithwood, Sun, \& Pollock, 2017). Information about the community members and their experiences in the democratic micro school is missing from academic literature. The practical application of this study serves to share how members of a micro school community experience leadership and democratic principles. While there is information about newly founded democratic micro schools, this information is found primarily in non-academic sources such as magazines and school websites. There is little to no information on the experiences of individuals leading and learning in a democratic micro school. One way to consider the leadership experiences of democratic school community members would be to consider the established relationships between community members.

The Leader Member Exchange (LMX) Theory focuses on relationship building characteristics between leaders and followers (Northouse, 2016). When considering the 
role of deep learning in a micro school, the connection between leaders and followers (students) is to have established a strong committed relationship to the learning process. In addition to building strong relationships with followers, LMX theorizes that the followers can be divided into an in-group and out-group (Northouse, 2016). However, the existence of these two groups may be mitigated by high-quality exchanges between the leader and the members.

Brower, Schoorman, and Tan (2000) focused their research of LMX theory on the relationship between leader and subordinate. Their model introduces the idea of trust into the relational components of the LMX Theory. In the democratic micro school being studied, while the structure is considered flat, there may or may not be the existence of power differentials between the students and the educators. A central theme to a democratic school would be how the members of the school organize learning, develop plans based on interests, and follow a path which informs curriculum (Wallin, 2003;

Woyach, 1992).

\section{Democratic Principles}

The democratic school philosophy includes several key themes that were used to establish the principles for this study. Hiatt-Michael (2001) identified four key components necessary for a learning community to exist: the existence of a servant leader, a shared purpose within the school community, a sense of trust and respect amongst the members of the school community, and an environment open to collaboration in the decision-making process. McCormick (2017) identified four key pillars to democratic education: inclusive decision-making, sense of community, shared vision and goals, and individual growth. In creating an analytical tool for studying 
democratic schools, Woods and Woods (2012) identified four different themes necessary for a democratic school; these included: transforming dialogue, holistic well-being, power sharing, and holistic meaning.

\section{Model}

From the key themes identified as democratic school philosophy and those central to the LMX Theory, the researcher established six key principles essential to understanding how leadership is experienced in a democratic micro school. The main principles of the model include: communication, vision and goals, community, equity, curriculum and interests, and trust and caring. Figure 1 shows the connection between the LMX Theory and the key principles in a democratic micro school (Northouse, 2016).

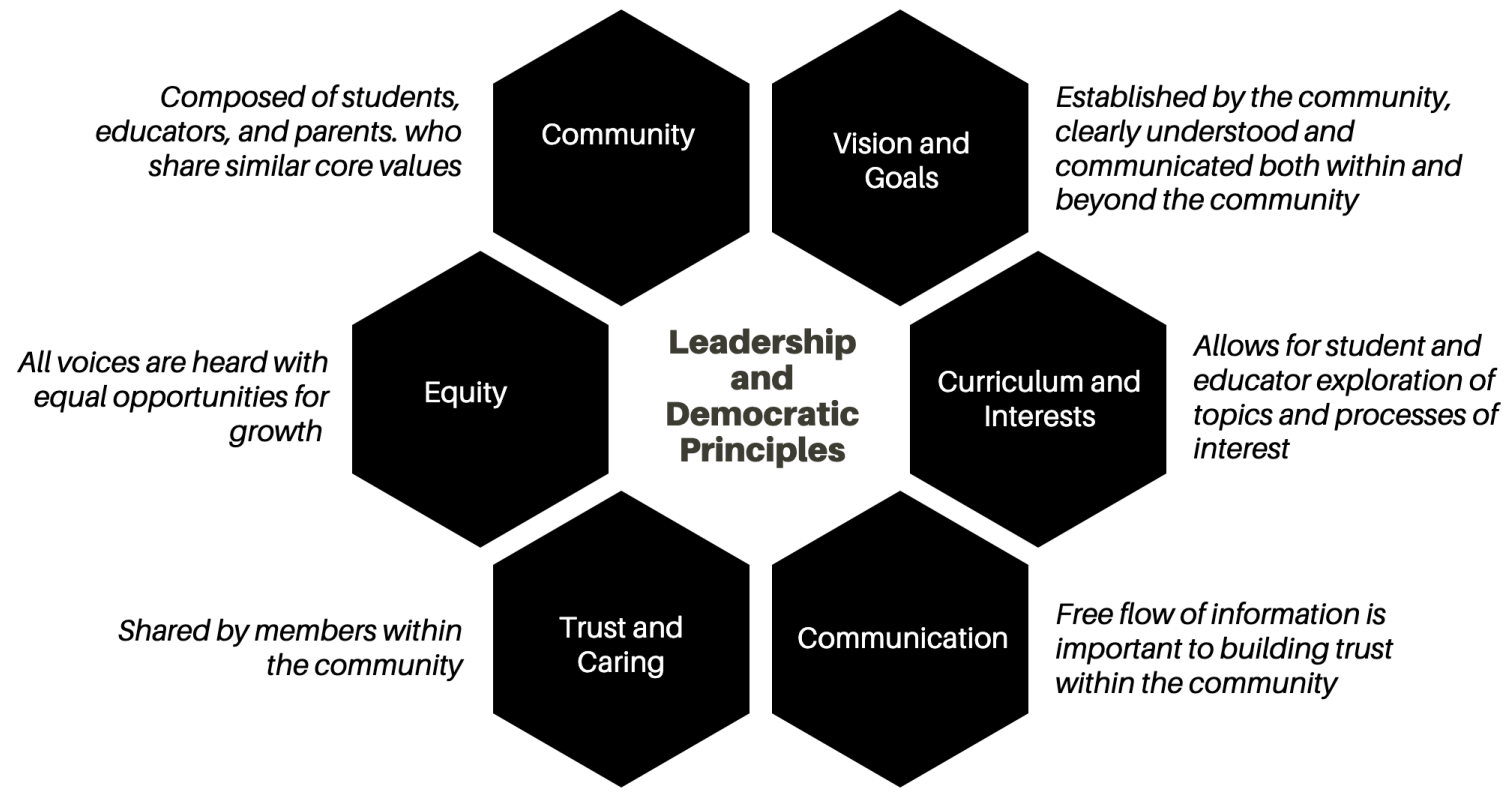

Figure 1. Leadership and Democratic Principles of a Democratic Micro School. Synthesis of LMX theory and democratic micro school. Summarizes the central components of both leadership and the democratic school. These six components represent the intersection of LMX Theory and democratic micro school philosophy (Hiatt-Michael, 2002; Hoerle, 2015; McCormick, 2017; Northouse, 2016; Ratnavale, 2017; Woods \& Woods, 2015). 


\section{Model Definitions}

Communication. Communication is an essential part to the success of any organization. In a democratic school, the lines of communication are plentiful as this tenet is a necessity for success in the other five. Omilion-Hodges and Baker (2017) found that the type of communicative exchanges that took place between leader and members played a large role in determining the relationship shared between leader and member.

Trust and caring. Two important factors within a school community are the sense of "belongingness" which relates to a central theme of LMX Theory in that trust is also important between leader and member (Schulte, Shanahan, Anderson, \& Sides, 2003).

Equity. In a flat leadership structure, all voices should be heard on equal ground, regardless of who is speaking (Preskill \& Brookfield, 2009; Hatch \& Schultz, 2002). Who is being heard and how they are being heard are essential parts of leadership in a democratic school?

Curriculum and interests. A central tenet to the democratic school philosophy is the right to self-determination in studies and experiences, giving students choice in their learning and endeavor is an important opportunity. (Korkmaz \& Erden; 2014; Woods \& Woods, 2012).

Vision and goals. McCormick (2017) and Woods and Woods (2012) identified the necessity of the members to work together to create a vision and set goals. This is a key component for any democratic school as it involves collaboration and working together to create a vision and path for the future of the school. 
School Community. The individuals who compose an educational organization is usually composed of students, parents, and educators.

The purpose of this study was to develop a better understanding of the lived experiences of the members of a democratic micro school community, especially regarding leadership and democratic principles. Using a mixed-method design with an embedded phenomenological case study to analyze a single democratic micro school, this study addressed how members of a democratic micro school community experience leadership and democratic principles. All primary stakeholders in the school community were subjects of this study including the founders/educators, students, and parents. The data collection process included a survey, focus groups, interviews, observations, and artifact analysis of information found on the Internet.

\section{Research Question}

How do members of a democratic micro school community experience leadership and democratic principles? Specifically, in terms of
a. communication
b. trust and caring
c. equity
d. curriculum and interests
e. vision and goals
f. community

Building relationships within the democratic school community is an essential part of creating the opportunity for a democratic school to have a personal and deep learning focus (Hoerle, 2015; McCormick, 2017; Ratnavale, 2017; Woods \& Woods, 2012). 
Using the central principles identified for democratic schools and the theoretical model for the LMX Theory, the model in Figure 1 was established to help better understand how the members of a democratic micro school community experience leadership.

\section{Methods}

This study used an embedded mixed method design, including a phenomenological component to explore the experiences of the school community members. An initial survey with descriptive statistical analysis, interviews, focus groups, artifact analysis, and observations aimed to provide a rich phenomenological description of both the expected and the actual experiences of the school community members within the context of the democratic micro school (Creswell, 2014; Yin, 2014). A phenomenological study emphasizes the shared subjective experiences of several individuals (Creswell \& Poth, 2018; Merriam \& Tisdell, 2016; Moustakas, 1994). The inclusion of experiences by parents, educators, and students sought to describe the meaning of the common lived experiences in this phenomenon (Patton, 2015). The school in this case began its third year of operation in the fall of the 2018. For this study, participants representing all types of members in the school community shared their lived experiences of leadership and democratic principles within the context of a democratic micro school.

\section{Setting}

The setting for this study, Dashwood School, (pseudo named) currently serves students ages 11 and over in a mid-sized Midwestern community. Ages 11 and over typically represent grades six through twelve in a traditional school setting. However, Dashwood does not assign students to grades but rather focuses on the students and their 
learning (Organization Website, 2018). One way this is supported is by the physical space the school occupies. The school occupies a large room with dividers. Within the

space are a myriad of tables, couches, comfy chairs, and a variety of equipment that could be used for creative learning endeavors. In addition to Dashwood, the surrounding community has approximately 10 independent schools of varying sizes. Dashwood began its third academic year in the 2018-2019 school year. Because Dashwood is so new, it is in the process of self-monitoring in order to work towards accreditation. The school further describes itself as private, independent, and using a democratic model.

The school relies almost entirely on tuition to sustain itself. It has been designed to have very low overhead by occupying primarily public spaces. Further, the school does offer financial assistance and hopes to attract students and families from underserved and underrepresented communities. The school frames its academic learning model within the context of state generated standards but admits that the selfdirected nature of its programming allows for increased latitude and choice for the students, teachers, and families. Further, the school also uses the community as part of its education structure by using workshops, activities, and other opportunities provided by community organizations (Organization Website, 2018).

\section{Participants}

Study participants represented key constituents of the school's community. These were: educators, current members of the student body (students), and parents. Throughout the reporting of this study, each of these groups will simply be identified by their member level in order to maintain the highest level of confidentiality. The 
phenomenological nature of this study considered the participants as co-researchers (McCormick, 2017; Moustakas, 1994; Yin, 2014).

The recruitment of participants occurred using traditional email and through a presentation to the student body. Convenience sampling occurred as those interested in participating in the study voluntarily completed the survey and some further consented to an interview (Fink, 2017; Merriam \& Tisdell, 2016).

Educators. The role of the educators in the school is to provide learning experiences to address the students' needs and goals (Organization Website, 2018). All of the current educators completed the survey with two of those also participating in the focus group.

Parents. These are the individuals making the choice to send their child(ren) to this school. In this school community, the number of parents is between 30 and 40 . The parents were initially contacted through school email. The number of parents who completed the survey was 18 with four of those agreeing to participate in interviews.

Students. Students' experiences of leadership in a democratic micro school are important as they are at the center of the school community. Eighteen of the 23 students chose to participate in the survey, and of those, eight chose to participate in the focus group. Of the eight students, two remained silent during the focus group, with four doing the majority of the talking and occasional contributions from the other two. In keeping with the democratic norms, students were allowed to respond or not as per their personal decision. 


\section{Data Collection}

The primary researcher collected data from multiple sources and through multiple means (Creswell, 2014; Merriam \& Tisdell, 2016; Yin, 2014). The primary types of data collected included public artifact data collected from the organizational website, survey data, focus group and interview data, and observations. The role of the mixed method study was to present the most complete picture possible using the data sources that allowed the findings to "make sense" (Creswell, 2014). Descriptive statistics were used for the survey data. The focus groups and interviews provided a deeper, more detailed account of the experiences of the school community members. Data collection occurred over a span of three months during the fall of 2018.

Artifacts. Data collected were analyzed using a seven-topic framework, derived from the framework shared in Figure 1, along with an "other" category to catch other relevant information.

Survey. The survey questions were the same for all members of the Dashwood community. Those individuals ages 18 and older were asked to complete the survey electronically through email. Those individuals under the age of 18 completed the survey on paper. This process was used to ensure that necessary parental consent and minor assent for participation were obtained.

Interview and Focus Groups. Students and teachers participated in two separate focus groups. Due to scheduling constraints, parents participated in individual interviews to share their ideas and perceptions within that construct of the democratic micro school (Krueger \& Casey, 2015). In choosing to compose three different categories of community member (students, educators, and parents), the questions allowed exploration 
of how the members experience communication, vision and goals, community, equity, curriculum and interests, and trust and caring.

Observations. Formal observations occurred over 7 hours on one complete school day and four other shorter informal visits to Dashwood across an additional 5 hours. The researcher was able to observe all manner of activities that occurred during a single day, including a community meeting, committee meetings, and other events.

\section{Data Analysis}

The goal of data analysis focused on making sense of data within the context of the chosen mixed method approach (Merriam \& Tisdell, 2016). The analysis of the focus group and interview data occurred using a phenomenological approach. The other unit of analysis used frequencies and percentages to provide a description of the members' experiences relative to the six key features shared in Figure 1. Together, the primary researcher analyzed the data using a side-by-side approach. Both the descriptive statistics and the focus group questions addressed community, vision and goals, communication, trust and caring, curriculum and interests, and equity. The descriptive statistics aim to address the broader views of the whole community while the focus groups aimed to allow for the students, parents, and educators to share their perceptions, thoughts, and feelings.

First, to increase validity, triangulation was used by considering multiple sources of data using constant comparison methodology (Creswell, 2014; Moustakas, 1994; Merriam \& Tisdell, 2016; Yin, 2014). Moustakas (1994) described the importance of first-person reports of lived experience and described steps in analyzing data, including Epoche, Phenomenological Reduction, Imaginative Variation, and Synthesis. The first step involved setting aside personal ideas and thoughts relative to the topic being studied, 
or Epoche, a preoperational stage of phenomenology. The second step is the process of phenomenological reduction. After reading through the interview and focus group transcripts several times, the primary researcher analyzed the data for significant statements, generated potential meaning units, and developed initial descriptions.

As the phenomenological frame focuses on shared experiences, all artifacts were coded openly considering the research question and sub-questions (Merriam \& Tisdell, 2016). The next stage used imaginative variation, which considered the ideas and findings from the reductive process from different angles (Moustakas, 1994). The researcher sought to add other potential topics or categories within the margins of the transcripts that were later used for data organization. As part of this process, the units were analyzed for recurrence and categorization occurred. The categories naturally emerged from the data but were strongly influenced by the central question and themes (Merriam \& Tisdell, 2016). Once initial categories were determined, each unit of data was assigned to a category, and the process of revision and refinement took place. In considering trends and categories across all data, triangulating the data provided strong case study support for the findings (Creswell, 2014: Merriam \& Tisdell, 2016; Yin, 2014). Study findings were further supported by fellow researchers.

\section{Findings}

This section will present the findings within the context of the six democratic and leadership principles upon which this study focused: leadership, communication, trust and caring, equity, curriculum and interests, vision and goals and community. Additional findings about the school community members' experiences beyond those included 
initially are also part of this section. Within these contexts, both quantitative and qualitative data will be presented.

\section{Leadership}

On questions regarding leadership a few different themes naturally emerged.

First, $71 \%$ of the community members agreed to strongly agreed that they have opportunities for leadership within the school community. No respondents strongly disagreed or disagreed. Members had a varied definition of leadership but centered upon two key ideas, leading oneself and leading within the school community. A key part of all leadership theory rests within those who hold the power to make decisions (Bolman \& Deal, 2013; Harris, 2013; Harris et al., 2007). The LMX Theory is predicated upon the idea of relationships between leaders and followers supporting the organization's goals. All participants felt relationship building was a key aspect of this community, particularly student-educators and student-student relationships. When considering how the community members experience leadership three main themes emerged: definitions of leadership, who is leading who, and connecting how members view relationships relative to leadership.

Community members definitions of leadership. How leadership emerges

within a democratic micro school should focus on the traits necessary for members of the school to organize learning, develop plans based on interests, and follow a path which informs curriculum (Wallin, 2003; Woyach, 1992). Members described the key attributes of a leader in the following way. One parent described a leader as "empathic, open-minded, responsible, and goal oriented." An interesting point that came up with the students was that the definition of leadership is often about leading yourself. One student 
commented, "Leadership isn't just leading others, it's also being able to lead yourself and figuring out how to make what you want to happen, happen and realizing that it's all you and you have the power to make those things happen but also, you have the power to just sit back and let them not happen." In a democratic school, members are expected to lead themselves in their own learning, but then when it is required, they may also assume a leadership role within the whole community.

The organizational structure of the democratic micro school is "intentionally flat." One educator commented that in this environment, "I think it more like pushing people to leadership, it's also not necessarily holding them by the leash anymore. Kind of letting it go." The educators also commented that "they often have to push back against the expectation that they are the leader." The student focus group further supported this from an experience where "The educator is like, who is going to lead this project and this project? Who's going to make sure we're responsible for all of this? Because it is not going to be me... and that's something that I haven't really noticed anywhere else before." This reflects the strong desire within the community to allow decision making to happen more organically.

Who leads who? Adding additional thoughts about who is leading who within the organization, a student commented "that they're opening it all up and you can [lead] anywhere you want, they'll help you." In one community meeting, the educators encouraged a student to lead the discussion, and as the meeting progressed, feedback and help were provided as necessary. In this environment, it seemed that anyone who was interested in leading would be given the opportunity to take on the role; this usually occurred if there was a topic the student or educator was particularly excited about. The 
willingness of school community members to adopt leadership roles likely occurred because of relationships.

Building relationships. One parent summarized the importance of relationship building as follows: "I would say, in the sense of being a leader who influences others, leads through influence... because people admire you and respect you, then the relationship is most important." This was supported across all of the focus group and interview conversations. The organizational website even supports this in stating the size of the micro school allows for each student to create the school where they will learn to their greatest potential (Organizational Website, 2018). This occurrence also speaks to the importance of equity in the school community in encouraging students to speak out.

\section{Communication}

Regular technology use by members of the school community was apparent, $83 \%$ of the respondents agreed to strongly agreed that they used technology regularly as part of the role in the school community. The use of technology is evident in a variety of aspects of the school community. In some cases, technology supports the the work of students and educators by allowing students to choose topics for discussion at weekly meetings. One student shared the following ways in which they are encouraged to communicate: "Our thoughts and ideas can be expressed verbally, through emails, or through our blogs." Other ways community members from each group shared how they communicated with each other included: "In activities like meta hour, community meeting, and judicial committee, I [am] able to hear and discuss w/ people about thoughts and concerns." 
Active blog life. The school blog has a variety of topics where both curricular topics and weekly discussion points are shared. In addition to this, the students share their learning progression using blogs. Each student creates a blog portfolio that enables them to share their learning progress towards competencies and experiences as a member of the school community. One factor to this is the students provide feedback to each other about each other's blogs, which further supports communicating learning and meeting the collaborative expectation of the school community. This encourages students to view each other's blogs and presents a significant component of intersection for many democratic principles. At the conclusion of their studies at Dashwood School, the student's individual blog shows progression towards competencies and creates a portfolio for college admission.

In addition to the student created blogs, other blogs include a variety of information about curriculum including videos for interested students to watch. The educators and students put topics into the blog, and those that are interested in being a part of the topic or collaborating to learn more work together to increase understanding of the topic. Perhaps the most significant component of the blog is the use of it to share potential topics of discussion at community meetings. One parent shared the importance of the blogs in the following way: "We are signed up for the school blogs, so we always receive the highlights of school activities and can ask our student if we want more details."

Community meeting. The weekly meeting takes place first thing in the morning once a week. The weekly community meeting is the way in which many respondents stated they shared their thoughts and ideas with the whole community. They also 
indicated this was the primary location where they heard what their fellow community members had to say. These meetings are usually led by a student volunteer. All students are encouraged to lead at some point. The researcher observed one such event when the student was a bit nervous to do so but was well supported by both the educators and the community. It was observed that not all students chose to attend the weekly community meeting. Some students were in the other spaces on their computers or talking while the meeting was taking place. One student shared, "We have a variety of committees and classes. In each of these, we are encouraged to speak up about our opinions, thoughts, and ideas. We are also taught to respect the thoughts of others whether we agree with them or not. Our thoughts and ideas can be expressed verbally, through emails, or through our blogs."

\section{Trust and Caring}

Perhaps one of the biggest aspects of trust in the school is the physical structure of the school. Though it the school occupies one giant room, there are dividers that create three fairly distinct spaces. Students move freely throughout the space and educators primarily work in the front "room" and then circulate periodically to potentially participate alongside the students in an activity or to help lead a learning activity. In considering the quantitative data for trust, contrasting views appeared. Ninety-two percent of the school community members agreed to strongly agreed that other members of the community could trust them. In contrast, $72 \%$ agreed to strongly agreed they could trust other members of the community.

Solving conflict helps us grow. Members of the school community serve on a variety of committees. One such committee is the judicial committee. This committee's 
primary concern is to maintain discipline and work with fellow school community members when rules are broken. This committee has the ultimate responsibility of trust from their fellow community members. They make observations and share those within the committee. These community members may sometimes also be the conduits to which their classmates report concerns. Bigger concerns may end up being taken to the whole school community to generate or create new rules, or they may stay within the committee.

You be you. One student stated, "I also think authenticity is important, like if people who are authentic in their own personality, which sometimes is less relationshipbuilding, but at least it feels genuine and kind of their---it's coming from their own personality as opposed to top down." Another student shared, "You can do whatever you want and there's going to be people around you to help you along the way." In talking about the opportunities that exist for the individual students, another a parent shared, "I would consider [student] a very introverted person, that has seen the need for an older person to step up and lead, direct or mentor, the younger kids and [student] has done that, so that's pretty cool to watch." The organization website (2018) also shared the focus on individual learning gives the students the opportunity to learn as they are. This was further supported by a parent, "I love that my child's teachers know him." And a student shared, "Also, the teachers, and most of the students, generally care about you and want you to succeed." Part of the success of the students within this environment relies on how members feel connected over multiple years. One parent put it very thoughtfully "having that relationship over multiple years is nice because I know them (the educators) and I trust them." 
Connected like a family. The connectedness between the community members combined with the assertion that at times the community felt like a family was apparent through a couple of different sources. The organization website shared that one goal of the school was to forge the relationships between students and adults in order to help the students further their learning. A student shared, "I really like that personal connection. And it's really weird to say this but you do feel, you see these people every single day... Like family." Another student stated, "We're kind of like a family, it just opened me up to talking to more people and getting to know people." Another student also shared the following:

So being able to know everybody closely and personally, it's really something...I'm very grateful for that, and being able to just be thrown into this room, just literally thrown in there with a bunch of people, and at first, you don't know any of them, and then things change, and you really love everyone.

Another student echoed their love of the connections and how it is one of their favorite parts of being a member of the school. The importance of the connected school was further supported by the organization's website (2018) which emphasized that in being connected, the students have the opportunity to learn from each other, from their local community, and from the great world.

\section{Equity}

In considering equity in the school, one student shared:

What I love is that I get to see almost everybody at the school in the same room... And what I most love about the school is that (it is) non-discriminative. Not 
discriminating your gender, your sexual attraction, or anything like that. It's the message of the school that we're all equal. That's what I love about it.

In a democratic school having an equal voice is an important effort for the whole community, $95 \%$ of all survey respondents agreed to strongly agreed that they listen to other members of the community when [those members] are sharing their thoughts and ideas. In addition, $80 \%$ of the respondents agreed to strongly agreed that members of the school community are given an equal voice in decision making. This question received the widest range of response from the students with $73 \%$ agreeing to strongly agreeing with the statement. The rest slightly agreed, and one disagreed with the statement.

When discussing equity within the school community, an educator shared the key was to "work well together, listen to each other, respect each other, respect everyone's opinion here if I don't really particularly like the person." When considering the importance of all voices being heard, one student shared, "there's a lot of kids that get an opportunity to have a say and, in a way, lead something that they're maybe passionate about. Lead a discussion or propose an idea or something that they need to change." A parent further supported "I like that [student] has a voice and that [student] has been able to assert themselves in different areas. I think they [educators] have been really fair and patient."

\section{Curriculum and Interests}

When considering how decisions are made, $91 \%$ of survey respondents agreed to strongly agreed that they were allowed to participate in making important decisions. Another interesting part of this is that $75 \%$ agreed to strongly agreed that they felt included in important decisions at the school. These respondents felt mostly a part of the 
decision-making process at the school. In terms of exploring topics of interest, $89 \%$ of respondents agreed to strongly agreed that they were able to explore topics of interest to them in the school community. This is further supported by the organization website sharing the importance of students having the right to choose their path of interests and studies. In considering the data collected, two major themes emerged, the freedom to follow personal interests and the importance of democratic responsibility. Balancing these two is similar to the yin and yang, each must happen in order for the school to be successful. When considering how this school might appear on the outside, one educator commented, "It looks different, feels different, and is different. We measure it differently, and we think differently." Another educator further supported this, "I think my experience here is different every day because every day is different."

The Yin: Self-interest. "Learning's best when you are motivated by your selfinterest." This is how one educator shared their thoughts about the opportunities to learn at the school. A student shared the following; "The best thing about it [the school] is just the opportunity to just experience things you are interested in." The opportunities provided by such an open curriculum moved one student to share that "It's definitely gotten me out of my comfort zone quite a few times- to where I'm talking to people- and I used to be really shy." There is a collaborative spirit in the freedom of the curriculum. A parent shared:

My child likes to really go down below the surface for knowledge and it's been a great experience to see them in a school where they have their information, can present it and there's a collective group that can either add on or say, 'You need to recheck your facts on that'. 
This openness is another example of the intersection of many of the democratic principles as individual endeavor is supported by the community, there is trust and caring in seeking feedback about topics of interest, and communication of their learning and feedback can occur using the school blog.

And the Yang: Democratic responsibility. One topic that resonated with several community members was the challenge of maintaining balance within the freedom of the school's democratic construct. One student shared:

Probably being able to balance the downtime, and social with the school part of it, and trying to learn. Because, yeah, I'll have lots of days where I'll be like, "Well, dang it, I haven't done anything today." And I'm supposed to be figuring out what I want to do.

When discussing the internal struggle of trying to find balance in the concern for learning and the freedom one parent shared, "I can see the anxiety of not know what's coming, not knowing how to fill a day. I think there was guilt because of playing video games for three hours at school. And the concern that no learning was taking place.” Echoing this, a student shared:

The main struggle is like, I could stay here and watch YouTube videos for five hours and no one will say a thing...But there's a different consequence than getting in trouble or getting detention like you would at some school. It's like the guilt. The personal guilt of feeling like I made the wrong decision today. And I spent my whole day making the wrong decision. But you also kind of realize that it doesn't just affect you. You have these responsibilities. And if you're choosing to not live up to those responsibilities throughout the day then you're not just 
going to feel personal guilt but you're also going to — other people are going to be like... maybe we shouldn't trust this person.

\section{Vision and Goals}

The school website describes the school as being based upon three different models. This creates the initial vision of the school which is to follow the democratic school model, to maintain the flexibility of a micro school, and to encourage connection between the students, the local community, and world. The members work to achieve this vision in a variety of ways but perhaps most significantly through authentic and individually relevant experiences. One educator provided the following thoughts about supporting leadership within the vision and context of the school:

There are certain people that I think naturally gravitate towards taking on leadership roles but to be able to see students who in a different environment wouldn't take the opportunity stepping up to the plate because there's kind of shared goals, shared objectives. There's a sense that leadership needs to happen. So, I've seen students- [whom] I think by their nature would avoid it if they could get away with it, who step up to the plate because they agree with the longer-term goals and they see the need.

Another parent shared that in this environment "The sense of shared goals had been built up over time. The belief that he could do that [lead in something that was personally important] and would be allowed to do that even." Within the context of the overarching vision of the school, the students are able to create goals that are personally relevant and thus creating the authentic learning that the school strives to achieve. 


\section{Community}

There are two sub-communities within which the members of the school primarily interact, the first is intra-school community which included the parents, students, and educators. The second is the extra school community which is composed of individuals who come into the school community for short vignettes or activities. There are several interactions that take place briefly or in a prolonged way throughout the regular school day. The community members in this case study were defined as parents, students, and educators; however, the existence of the greater community surrounding the school becomes particularly prevalent when considering how the students are encouraged to participate in activities beyond the school.

Intra-school community. Seventy-eight percent of the members agreed to strongly agreed that they are a valuable member of the community. Seventy-five percent agreed to strongly agreed that they share similar values to other members of the school community. Of greatest interest is the response to the statement "sometimes I struggle to feel like I am part of the school community" to which over $39 \%$ of respondents disagreed or strongly disagreed.

When speaking about their fellow community members one student stated, "My friends all share similar interests with me, so it is very easy to communicate with each other about my thoughts and ideas. They are all very supportive of me." Another student shared, "I know that for me, it's been really wonderful getting to become friends with other people who all have these other skills and talents that I don't have... and you don't feel like you have to take control of things all alone. You can lead projects alongside 
other people I guess." In addition to the students being encouraged to work together within the community, there are other ways the educators work to build camaraderie.

One way the educators do this is by creating a conversation starter that might last over an extended period of time. For example, a tournament bracket called "Animal Battle Royale" was posted on the community white board and incited several thoughtful conversations and research about the various animals within the draw. Another reflection of the intra-school community was the use of a blogs. Blogs served multiple purposes within the school, perhaps most significantly as a way to communicate the weekly announcements and schedule for the school. Blogs were also as a way for students to create a learning portfolio where they showed their learning and understanding about the various topics they chose to research and study. Within the community, leadership skills are built by opening the floor for students to lead weekly meetings and present topics of interest to their fellow school community members. Blogs share learning with the community and provide opportunity for reflection.

Extra school community. One outside presenter stated, "I want to make sure that what I am doing fits into what you are working on." The outside community presenters are experts and willing to share knowledge with the community; however, ultimately, they are treated to the same democratic precepts experienced by all members within the community. They are at the whim of the students and the educators. Several individuals were observed visiting the school to share various activities with interested students. Some were better received and more popular than others. 
The school's size also enables the school community to take advantage of larger community resources including sports facilities, libraries, and parks. These extra-school interactions are often mediated on a project basis. One student shared the following,

For example, the Community Magazine, it's like I'm not necessarily good at interviewing people...But I am good at writing papers and stuff like that. So, if some like [student] is able to interview the person then I can tape the interview and write the paper from that interview.

The student went on to comment that in a traditional environment they might have expected to complete all aspects of the project alluding that they were particularly fond of the teamwork opportunities. Other focus group members nodded agreement as their classmate spoke.

While this study focused on the intra-school community, it is impossible to not acknowledge that the extra school community plays a large role in supporting student opportunities for leadership. These two intertwine to impact the experiences of all members of the school community.

\section{School Can Not Be Everything, Even Though We Want It to Be}

Other categories emerged throughout the data collect, including the idea that today's schools need to change in order to address student needs, and there are challenges to be a member of democratic micro school community. A strong majority, $95 \%$, of the school community agreed to strongly agreed that their experience as a Dashwood School community member has been positive. The importance of having a school such as the democratic micro mchool was highlighted by a parent: 
I think there's something broken in our educational system and I really don't know what the answer is to that other than we've got to stop looking at the educational systems as being the cure and the problem because it stems from our culture and we've got to recognize those differences, a one size does not fit all. However, even within the context of a democratic micro school there are challenges beyond those already shared.

One significant challenge that emerged in the course of the research, was that there are times when the sheer difference in ages of the student population present social and emotional challenges. Success in creating the structural and curricular balance to support the learning for all of the students is a hope that one member shared. Another challenge that emerged was potentially an over reliance on technology. In one case a parent shared, "We talk a lot about how [student] doesn't want to learn things on a computer. It's just that computers are for entertaining, not for work, and I think that's hard." And last in considering the whole of the school community, some members, particularly parents, wished to be more involved but were prohibited due to scheduling challenges, e.g., they worked during the day and hoped they could be more involved and take part in the camaraderie shared by other members of the school. One member shared, "I'm willing to participate in ways that would be beneficial to the school, but I'm not understanding what that is all the time." And lastly, one member shared the following challenge, "There are times when I feel like there is such an adherence to a commitment to the flexible school day, flexible learning style that sometimes-wanting flexibility is turned into being inflexible about what your needs are and meeting those needs as they come." 


\section{Community}

- Intra-School

- Extra-School

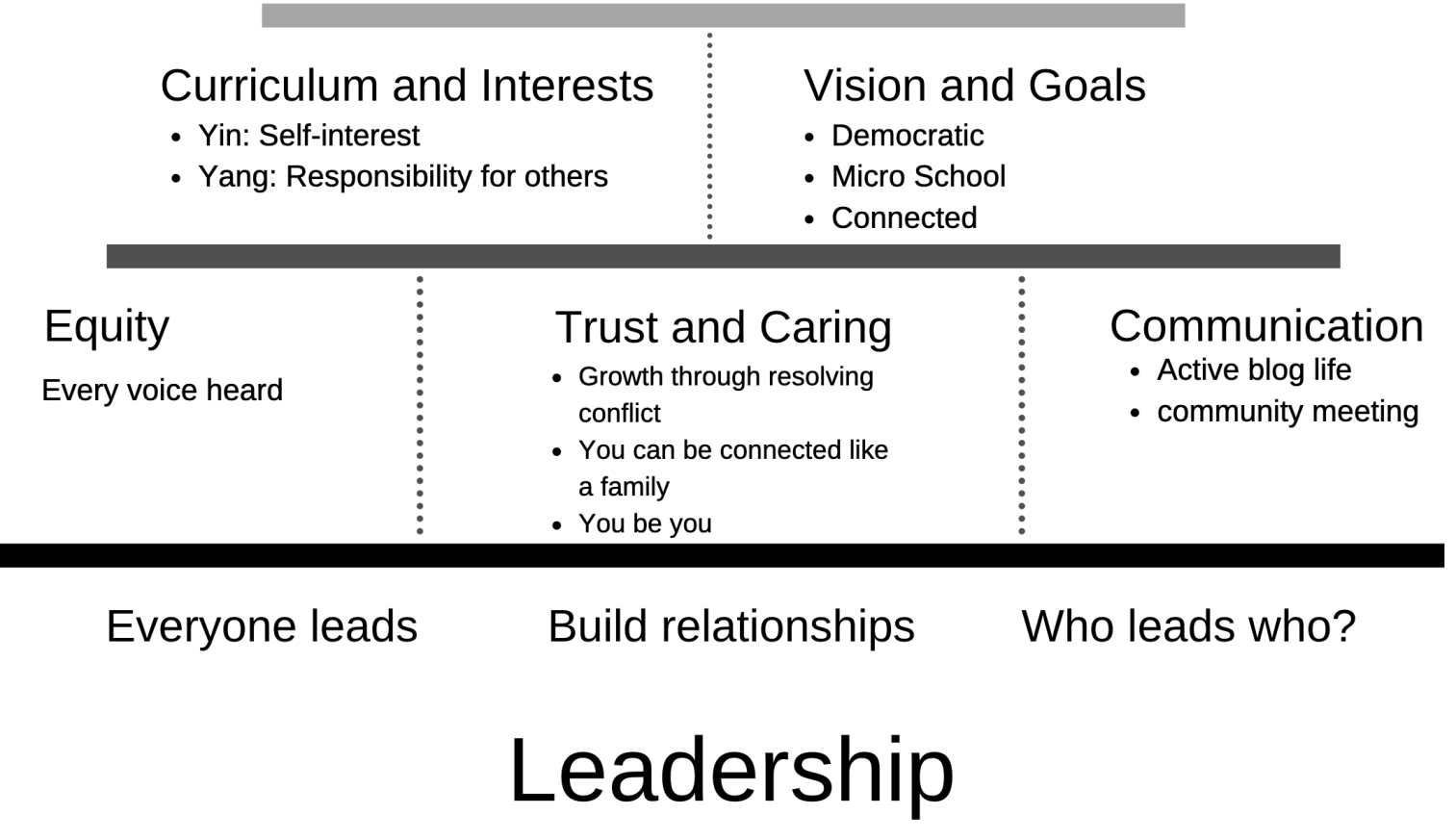

Figure 2. Reimagining of leadership and democratic principles in a democratic micro school considering the research findings.

\section{Discussion}

Figure 2 shows a reimagining of Figure 1 further establishing the connection between the six democratic principles used in this study and leadership. The purpose of this research was to consider how community members of a democratic micro school experienced leadership and democratic principles. The intersection of experiences is composed of the central components of the LMX Theory, building relationships and supporting leaders and followers in the learning community thus providing the base for the six democratic principles: communication, trust and caring, equity, curriculum and interests, vision and goals, and community (McCormick, 2017; Northouse, 2016; Schultz, 2010). Time spent at Dashwood School aimed to provide a rich description of how 
members of the school community experienced leadership and democratic principles. The value of building relationships strongly impacted the three foundational democratic principles: trust and caring, equity, and communication. The experiences of the community within these three principles provided the ability to develop the curriculum and interests and vision and goals that ultimately define the school community.

\section{Leadership}

The community members shared two key thoughts about leadership, first, perhaps the most expected was the process of leading others, the other focused on the importance of leading oneself. Given the importance placed on decision making in terms of governance, community, and personal learning experiences, the role of the leadership is a crucial part of the learning experience for each of the community members (HiattMichael, 2001; McCormick, 2017; Schultz, 2010; Woods \& Woods, 2015). The community members exhibited thoughtfulness about this in a variety of ways, first they shared the importance of building relationships with each other and then beyond the community. Several of the Dashwood community members expressed this as being a part of the family. Beyond this, they felt that it was a different experience than they might have experienced at a different school. However, when asked about building relationships with in the community, it was clear that building those relationships was really important (Northouse, 2016).

The importance of leading yourself was also a significant finding from this research. It seemed pretty clear that the members of Dashwood who participated in the interviews and focus groups felt that this was a crucial part of their experience within the community. An underlying impact of self-leadership is self-reliance (Brower, 
Schoorman, \& Tan 2000; Korkmaz \& Erden, 2014). Members of the school, particularly those between the ages of 11-18, are learning that they have the power to determine their learning. Their realization of this and the impact of impassivity was particularly poignant. The choices they made in their self-leadership had the potential to impact the larger community and they saw this a potential negative if they chose not to support the collaborative opportunities. Another significant impact to the importance of "anyone can be a leader" is that each member of the community felt that they had the opportunity to make things happen. Some had already been able to address issues that concerned them, others were still working on the skills to do so, while others may just be waiting for the right opportunity. Regardless of which category that Dashwood's community members fell into, the respondents to the survey all felt that they were able to communicate with at least one or more other members. These perspectives support the democratic ideals of the school (Bush \& Glover, 2014; Hiatt-Michael, 2001; Woods \& Woods, 2012).

If everyone in the Dashwood community can be a leader, or has the perspective that the opportunity is there, then there is a clear link to equity. Each community member has the opportunity to share their voice. The essentially flat structure of the school supports the opportunity for every voice to be heard with equal footing (Hatch \& Schultz, 2002; Preskill \& Brookfield, 2009). This was evident from how the members of the community freely shared their thoughts and ideas and embraced the opportunity to participate in this study.

Lastly, while everyone has the opportunity to lead, it is crucial that there are times when members are followers. The importance of relationships, trust, and caring enables members to adapt and be somewhat flexible within the constructs of the democratic 
school. Northouse (2016) and Omilon-Hodeges and Baker (2017) stated that some of the challenges of the leader-follower relationship can be resolved through high quality exchanges. When addressing the concept that everyone can lead, there is the counter to the leading which is following, or it is working and leading together. All of these roles were evident within the construct of Dashwood's connected, democratic, micro school philosophy.

\section{Democratic Principles}

In Figure 2, community is the pinnacle of the figure because the members' experiences of the other five principles define the Dashwood school community. The findings ultimately suggest the necessity of an expanded view of community. Individuals from outside of the school community are important to supporting the shared vision and goals, as well as, the learning interests of the students (McCormick 2017; Wallin, 2003; Woyach, 1992). Establishing the school community experiences are the vision and goals and curriculum and interests instituted through a strong collaborative mechanism, the community meeting. Together with trust and caring and equity, communication provides the support for members of the Dashwood community to inclusively decide what and how they will learn (McCormick, 2017; Woods \& Woods, 2012).

Hiatt-Michael (2001) identified that collaborative decision making was a central tenet for a learning community to exist. The daily and weekly community meetings are one experience shared between the members of Dashwood that included both collaboration and decision making. The opportunity for the students to actively be involved in planning, leading, and directing community meetings and committee work is 
evident; it is clear that communication is a crucial part of the program at Dashwood (Omilon-Hodges \& Baker, 2017; Korkmaz \& Erden, 2014).

In addition to the daily meetings, the use of technology further enhances how information is communicated between the school community members. Both information and learning are communicated by the use of blogs. Dashwood's communication of the learning process, not only within the physical construct of the school but also beyond the school community to the world, relies on the use of both educator and student created blogs. In another significant overlap, Omilon-Hodges and Baker (2017) maintained that practicing high levels of communicative exchanges positively impacted the relationships within the community. Furthering the connection, communication is essential to establishing the vision and goals for both the whole community and the individual. Clear communication of vision and goals supports opportunities for collaboration and support (McCormick, 2017; Woods \& Woods, 2012).

In considering the questions about trust, there was a difference in how the community members felt they could be trusted and whether they could trust their fellow community members. Within the community, $92 \%$ agreed that their fellow community members could trust them whereas only $72 \%$ agreed that they could trust other members. This is an interesting paradox and could perhaps speak to experiences of equity within the community. In addressing this, the shared connectedness to the school over multiple years helps to build trust within the community.

Members of the Dashwood community were able to build community through establishing relationships. It was upon these relationships that the principles of the democratic school thrive (Brower, Schoorman, \& Tan, 200, McCormick, 2017). Both the 
leadership and democratic principles experienced by school community members provide the necessary process of organizing Dashwood's learning experiences (Wallin, 2003; Woyach, 1992).

\section{Conclusion, Implications, and Limitations}

Establishing a model and theory through which to consider the experiences of the members was essential to adding to the current scholarship addressing independent schools and new school models. The implication of this study includes creating a platform upon which other studies could potentially find use but perhaps most importantly to build the scope of understanding of what it is the be a member of an independent, democratic, micro school. As new school models continue to emerge in light of parent and community concerns with public education, researchers may potentially focus on these models in addition to their research on public education. The most significant limitation to this study was the inclusion of only one school in the case study. However, the researchers' hope that in delving deeply into artifacts, collecting multiple types of date from surveys, to interviews and focus groups to observations, that the researchers were able to establish a thorough picture of Dashwood's members' experience of leadership and democratic principles.

In the true democratic fashion, the research was a participative activity for those members of the Dashwood community who chose to participate in the study. One limitation to this choice is that other perspectives may have been missed from those who chose not to participate. The depth of data collected as part of this study aims to shed light on the experiences of those members who chose to participate in the study. It is in that final thought that the true essence of the democratic micro school experience shines. 


\section{References}

Bolman, L. G., \& Deal, T. E. (2013). Artistry, choice \& leadership: Reframing organizations (5th ed.). San Francisco, CA: Jossey-Bass.

Brower, H.H., Schoorman, D.F., \& Tan, H.H. (2000). A model of relational leadership: The integration of truest and leader-member exchange. Leadership Quarterly, 11(2), 227-250.

Bush, T. (2011). Theories of educational leadership \& management (4th ed.). Los Angeles, CA: Sage

Bush, T., \& Glover, D. (2014). School leadership models: What do we know? School Leadership \& Management, 34(5), 553-571. doi: 10.1080/13632434.2014.92860

Creswell, J. W. (2014). Research design: Qualitative, quantitative, and mixed methods approaches (4th ed.) [Nook].

Creswell, J. W., \& Poth, C. N. (2018). Qualitative inquiry \& research design: Choosing among the five approaches. Los Angeles, CA: Sage.

DiPerna, P. \& Catt, A. (2016). 2016 Schooling in America survey: Public opinion on K12 education and school choice. Retrieved from: https://www.edchoice.org/wpcontent/uploads/2016/11/2016-10_SIA-Poll-Update.pdf

Dronkers, J., \& Robert, P. (2008). Differences in scholastic achievement of public, private government dependent, and private independent schools: A cross-national analysis. Educational Policy, 22(4), 541-577. doi: 10.1177/08904807307065

Fink, A. (2017). How to conduct surveys: A step by step guide (6th ed.). Los Angeles, CA. Sage. 
Goleman, D. (2011). What makes a good leader? In HBR's 10 must reads on leadership (pp. 1-21). Boston, MA: Harvard Business Review Press. (Reprinted from RO4O1H, Originally published in June, 1996)

Harris, A. (2013) Distributed leadership: Friend or Foe? Educational Management Administration \& Leadership. 41(5), 545-554. doi: 10.1177/1741143213497635

Harris, A., Leithwood, K., Day, C., Sammons, P., \& Hopkins, D. (2007). Distributed leadership and organizational change: Reviewing the evidence. Journal of Educational Change, 8. 337-347. doi: 10.1007/s10833-007-9048-4

Hatch, M. J., \& Schultz, M. (2002). The dynamics of organizational identity. Human Relations, 55(8), 989-1018. doi: 10.1177/0018726702055008181

Hiatt-Michael, D. B. (2001). Schools as learning communities: A vision for organic school reform. The School Community Journal, 11(2), 113-127.

Hoerle, H. (2015). Sizing up the competition: Exploring educational choice in today's independent school market. (Report), The Enrollment Management Association.

Horn, M. B. (2015, Summer). The rise of AltSchool and the other Micro Schools. Education Next, 15(3). Retrieved from http://educationnext.org/rise-microschools/

Korkmaz H. E., \& Erden, M. (2014) A delphi study: The characteristics of democratic schools. The Journal for Educational Research, 107, 365-373. doi:10.1080/00220671.2013.823365

Krueger, R.A. \& Casey, M.A. (2015) Focus groups: A practical guide for applied research (5th ed.). Los Angeles, CA: Sage 
Leithwood, K., Sun, J., \& Pollock, K. (Eds.). (2017). How school leaders contribute to student success: The four paths framework. New York, NY: Springer. doi.org/10.1007/978-3-319-50980-8

Levi, D. (2014). Group dynamics for teams (4th ed.). Los Angeles, CA: Sage. McCormick, P. R. (2017). Leadership in democratic schools (Doctoral dissertation). Available from ProQuest Dissertations and Theses database. (UMI No. 10602433)

Merriam, S. B., \& Tisdell, E. J. (2016). Qualitative research: A guide to design and implementation (4th ed.). San Francisco, CA: Jossey-Bass.

Moustakas, C. (1994). Phenomenological research methods. Thousand Oaks, CA: Sage. National Association of Independent Schools. (n.d.). About. From https://www.nais.org Northouse, P. G. (2016). Leadership: Theory and practice (7th ed.). Los Angeles, CA: Sage.

Omilion-Hodges, L. M., \& Baker, C.R. (2017). Communicating leader-member relationship quality: The development of leader communication exchange scales to measure the relationship building maintenance through exchange of communication-based goods. International Journal of Business Communication, 54 (2). 115-145. doi: 10.1177/2329488416687052

Patton, M. Q. (2015). Qualitative research \& evaluation methods: Integrating theory and practice (4th ed.). Thousand Oaks, CA: Sage.

Preskill, S., \& Brookfield, S. D. (2009). Learning as a way of leading: Lessons from the struggle for social justice. San Francisco, CA: Jossey-Bass. 
Prothero, A. (2016, January 26). Micro schools could be new competition for private K12. Education Week, p. 11. Retrieved from http://edweek.org/ew/articles/2016/01/27/micro-schools-could-be-newcompetion-for.html

Ratnavale, S. (2017). OESIS learning innovation report on U.S. independent schools. Retrieved from Online Education Symposium for Independent Schools website: http://www.oesisgroup.org

Schuermann, P. R., \& McGovern, M. (2016). Introduction to independent schools: Issues and opportunities. Peabody Journal of Education, 91(5), 569-573. doi: 10.1080/0161956X.2016.1227160

Schulte, L., Shanahan, S., Anderson, T. D., \& Sides, J. (2003). Student and teacher perceptions of their middle and high schools' sense of community. School Community Journal, 13(1), 7-34.

Schultz, J. R., (2010). The scholar-practitioner: A philosophy of leadership. ScholarPractitioner Quarterly, 4(1), 52-64

Wallin, D. (2003). Student leadership and democratic schools: A Case Study. NASSP Bulletin. 87 (636), 55-78. doi:10.1177/0192636503087636606

Woods, P. A., \& Woods, G. J. (2012). Degrees of school democracy: A holistic framework. Journal of School Leadership, 22(4), 707-732.

Woyach, R. (1992, September). Leadership in civic education (ERIC Digest No. ED351270). Retrieved from https://files.eric.ed.gov/fulltext/ED351270.pdf Yin, R. (2014). Case study research: Design and methods (5th ed.). Los Angeles, CA: Sage. 
SECTION SIX: SCHOLARLY PRACTITIONER REFLECTION 
In April of 2015, I recall sitting in the PCOB room, listening to graduates of the EdD Program discuss how their experience throughout their coursework and research had changed their lives and the lens through which they viewed the world. My internal dialogue at that point was something like, "I am already pretty awesome and do not really see a need to make big changes." At this point, my response then about how I would now respond to myself four years ago would address how glad I am to have completed this process and how much I have changed for the better. The experiences through the program have definitely impacted me as a scholar and a practitioner.

From the first summer influencing my committee leadership in revising the senior capstone experience at the school where I teach, to listening to educators, students, and parents share their experiences of democratic micro school, I find a sense of calm, thoughtfulness, and analysis pervades in a way that I would not have expected. As I reflect, there are certain experiences and readings whose impact I feel as a both a new scholar and a practitioner are worthy of further articulation. In addition to considering how the EdD process has impacted me as an educational leader, practitioner, and a scholar, I am including two comparative infographics that I made during the fall of 2015 and winter of 2019. Lastly, the journey may seem to be coming to a conclusion, but really this is a beginning or perhaps a divergent continuation.

\section{How the dissertation Impacted My Practice as an Education Leader}

I have always been a team player; I have enjoyed the collaborative effort and camaraderie of working with a group of people to accomplish a common task. I am since embraced the idea espoused by Levi (2014) describing the purpose of a team but most importantly the process of a team. During summer one, I embarked on a leadership 
experience that followed the basic path of forming, norming, storming, ... until we completed our task and went our separate ways. It was amazing but did not end there. I then took the committee work and shared it with the whole faculty, solicited feedback, dealt calmly and thoughtfully with negativity and now that work is supported by the work of my colleagues who are still directly involved with that specific program. While I believe some of the process would have been the same, without the summer one experience, I strongly believe that it went positively because I had the collaboration and focused work completed throughout the process to use as a model for how I would both lead and follow in a team situation. Working together with fellow faculty on this task was a situation that ended positively, but I believe the greatest impact from this program has been on how I respond to challenging situations.

Each day, I am confronted with challenges that elicit pause and increased thoughtfulness. Over the last year, my life outside of my practice as a teacher has changed significantly, and the dramatic challenges tested my ability to deal with incredible conflict. The understanding that change happens in slow motion, is important and the gift of time helps to increase perspective. My ability to listen, hear the ideas of others, thoughtfully consider a response, reflect, and then choosing to respond or not respond helped with the forward motion of my life and the lives of those around me. I would predict that prior to my course work and collaborative projects, I might have found the process of moving forward comparable to climbing Mt. Everest rather than perhaps Pike's Peak. I don't know that I would be to this point today without the reflective practice from the EdD experience.

When thinking about leadership, we used Northouse (2016) to consider all of the different types of leaders that exist. Since then, I have found his work was certainly not 
exhaustive but perhaps, most significantly, in my dissertation research, the concept of selfleadership entered the stream of consciousness. What stands out most to me is that selfleadership sets the example for those around you. As a classroom leader, I have always felt the paramount importance of being a role model. This is the beginning of selfleadership. The next perspective that emerged for me was that leadership should also provide an example for fellow faculty. Through my actions, I hope to challenge my fellow faculty members to be better and to continue to grow.

As if to come full circle, in my early days as a teacher, I was able to attend two small conferences led by Peter Senge about sustainability in education. It was through the EdD process and returning to his books and the articles that we read as part of coursework that I was able to reflect on what an amazing experience it was. That was 10 years ago, and I am just now able to really contemplate the major leadership impacts from that experience. I finally have a way to frame it. And what I truly appreciate about the impact is the incredible intertwining of the democratic philosophy of education, the systems approach, and how my practice as a teacher continues to shift and change.

My research into the democratic school model further influenced me as a teacher. During the spring of 2019, I adjusted my curriculum to include a more student driven opportunity. The students in one of my classes were given the opportunity to complete a project completely of their choosing. In the beginning, some really floundered in trying to figure out what they would do with their time. For some of my students, they immediately embraced the opportunity and immediately got to work. At the conclusion of this project, I gave the students an informal survey and despite the challenges the freedom presented, the majority of students found the experience liberating. This evaluative feedback will 
undoubtedly inform my practice and impact how I would implement increased democracy in my classroom. Ultimately, that is the challenge, I have to make the conscious decision to more significantly give students the right to direct their learning. The paradox? I am still the one making that decision and driving the opportunity, the challenge in shifting that perspective continues.

I still have more questions than I will likely ever find answers, but I have more tools, perspective, process, and desire to find the best way forward for myself, my village, my community, and beyond. As a practitioner, I am excited to see how the future will unfold and how this work will continue to impact my life. As a scholar, I am excited to potentially research new processes, ideas, and more to expand the knowledge of both practitioners and scholars.

\section{How the Dissertation Impacted Me as a Scholar: Walk Through the Door}

I have to start this in considering the fact that I love hard science, I love research, I love data, and I love reading academic journals sharing scientific findings. I am pretty sure that I never would have considered the possibility of qualitative research before this experience. Truthfully, I find the interaction of completing the qualitative process is incredible. Finding the thread, the telling the stories of others is a great adventure.

The research process conducted to study democratic micro schools provided both a learning and reflective process. I will admit, I was exhausted after my first parent interview. I underestimated how challenging it would be to listen to parents talk about their children. This is interesting since as a practitioner I often to talk parents and discuss their children. There were admittedly moments when parents shared information that sent me into my head as a teacher and parent and I had to work very hard to detach and listen 
and hear their story as researcher. One thing that I really appreciated was the interest that my study participants had in my project and this experience. I am excited to continue to conduct more research although perhaps on a different scale.

Just the other day, I spoke with a colleague about how I would like to write an academic article about a yearlong "project" in her class. I am currently strategizing what I will need to do in order to move forward with my idea for this article. I have some idea of what the process will entail; doors are opening all around me. While I have the processes in mind to help me move forward, I also feel like I am capable of flexibility and will undoubtedly welcome the challenge that will arise as I work to define who I will be now. I think the work now is to help increase the scholarly opportunities arising from being a scholar practitioner in a lab school.

I am excited to continue to research both in my class and beyond, although certainly the logistics will be no less challenging. I feel an increased responsibility of being a K-12 practitioner with scholarly understanding to continue to research and share my findings. I also realized there are several different avenues to share my learning and hope to be able to do so. Being a teacher at a lab school, I am more compelled now to really be the scholarly practitioner that this process has helped me to better understand. The door is open, and the journey has become more important than the destination.

\section{Infographic (Before and After)}

As part of our summer one coursework, we completed a strengths inventory and were asked to reflect on how our strengths would impact our ability to collaborate with others (Rath, 2007). Following summer one, I taught a capstone for our seniors at Greenwood. Part of their coursework included completing the strengths inventory and 
reflecting upon what it might mean for their collaborations and provide a creative way for them to share information. As part of their assignment, I asked them to create an infographic to share their strengths and reflection. An infographic often includes pictures, charts, graphs, and words to convey thoughts and ideas. The first infographic was the one I created as an example to share with my students. The second, I updated recently as I reflected up our work during summer one. I think what is really conveyed through the comparative infographic is a shift in the depth of thought and understanding my strengths inventory. In the figure three, you will find the first infographic and my updated infographic. 


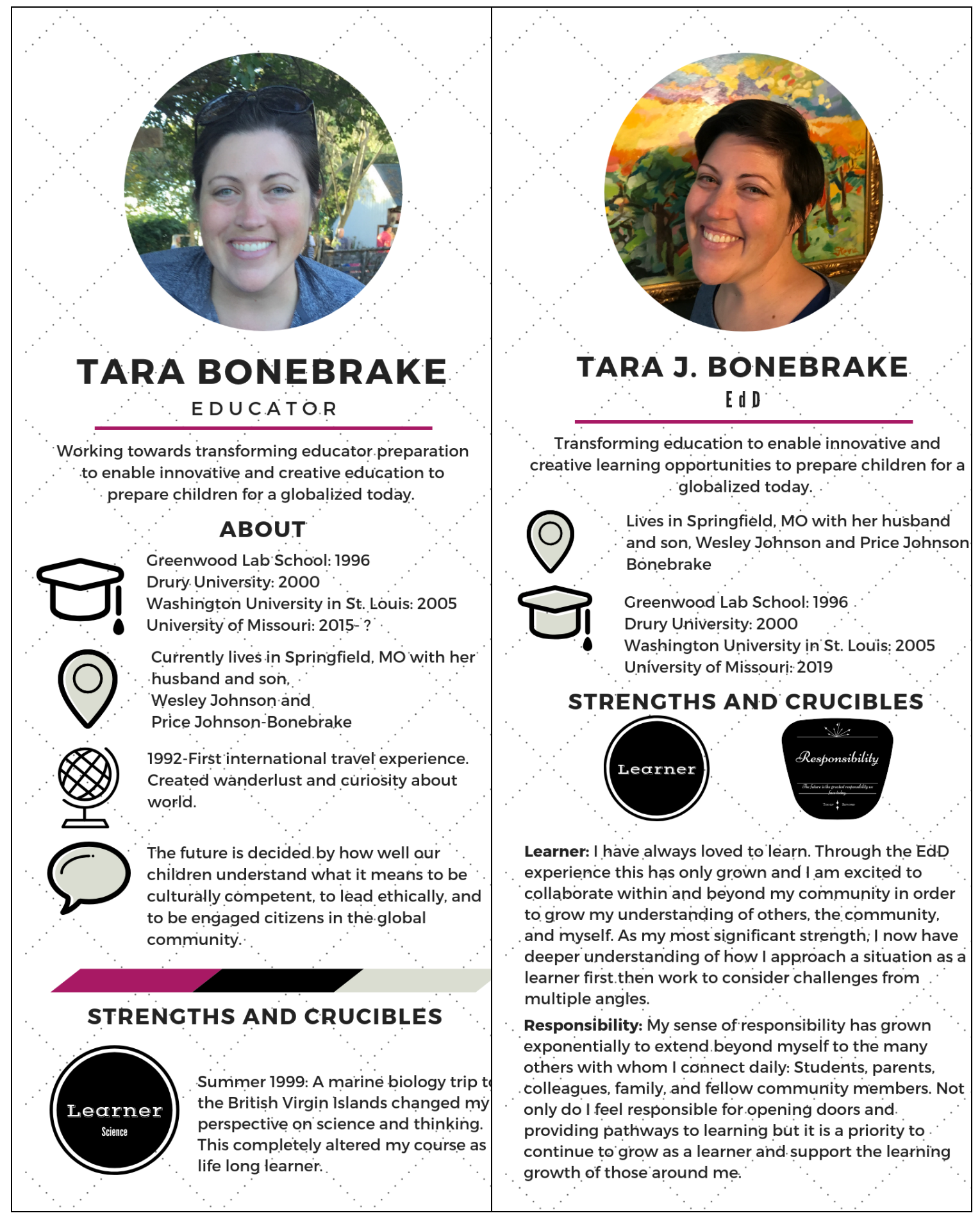




\section{STRENGTHS AND CRUCIBLES CONTINUED}

2001: Being an Americorps. volunteer teacher changed my thoughts about my responsibility to society and our children. My future as an educator started with this experience.
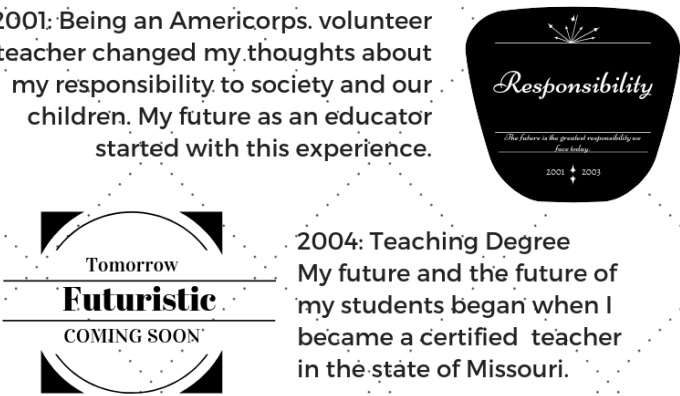

2004: Teaching Degree My future and the future of my students began when I became a certified teacher in the state of Missouri.

2013: Thinking critically about how to evolve an education program that reflects

the future of how to prepare today's population becomes paramount. Intrinsically tied to futuristic.
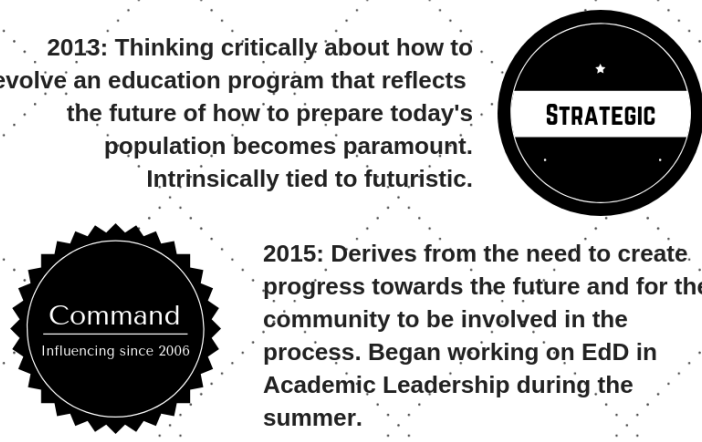

2015: Derives from the need to create progress towards the future and for the community to be involved in the process. Began working on EdD in Academic Leadership during the summer.

\section{THE FUTURE}

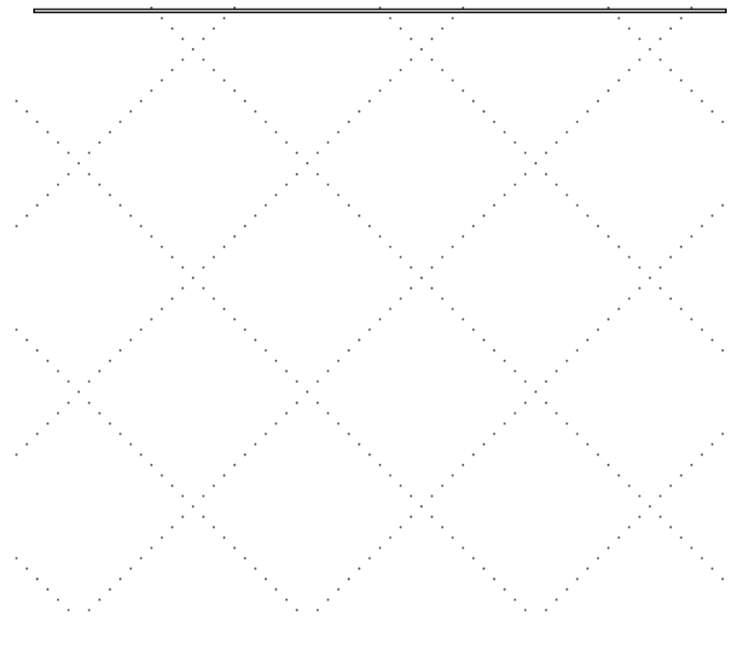

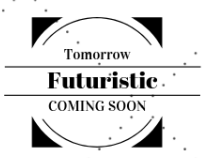
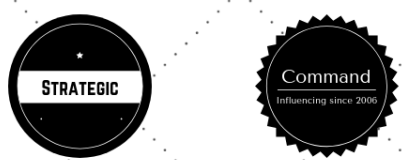

Futuristic: I have always wondered what the future holds. I plan and have plans upon plans and contingency plans. I do know that I want what is best for my students, their families, my family, and my community. I. know the future holds change and the EdD experience has provided more skills and tools to adapt than I could have imagined.

Strategic: Seamlessly connecting with futuristic to plan thoughtfully for the future. Today, I am more

empathetic and try to see challenges from more views. than ever before. My sense of responsibility has further fueled the need to be strategic in my process. I am . always learning, thinking, and planning.

Command: The EdD program has empowered me to consider how I can be a leader, how I can continue to grow as a leader, and how I might help support those around to better lead themselves and their community. think command also comes with an increase in self. confidence that perhaps has allowed me to strive for opportunities to support those around me.

\section{THE INCOMPLETE LEADEP}

It is not about where you end up...four years ago I.was a different person than I am today. Undoubtedly.; I would have grown and changed over time, however, the work in the EdD. has opened a realm of unimaginable possibilities. i started this path moving towards one particular goal. At the end of the process, I realize that the goal may not be important any more. If anything; I have more questions than I did before. I appreciate the idea presented by Ancona et. al. (2007/2011) that shares the four capabilities of a leader, "sense making, relating, visioning; and inventing" (p.187). I think these are the tasks of life defining questions. Through my research, I came to more deeply appreciate the concept of "self-leadership" and can't help but feel that in order to truly walk my very best path., must work everyday to live that which I espouse. Levi (2014) truly influenced my collaborative work as I find that. I approach each team situation with the idea of "forming, storming, norming, performing, and adjourning" (p.43). Connecting Ancona et. al. (2007/2011) and Levi.(2014) the tasks of leadership and beyond represent the necessity of building relationships and moving towards a common goal together. While the future is unpredictable, I am excited for the possibility and strategy to get there.

Figure 1: The reflection of four years in an infographic. The left shows the infographic from the fall of 2015. The right shows the infographic from January 2019. 


\section{The Journey Is Incomplete: Conclusion or Beginning?}

Not surprisingly, I have more questions about my future than I did before I started this program in 2015. There are more options now than ever before. However, there is a process shared by Ancona, Malone, Orlikowski, and Senge (2007/2011) that I think will be important to the journey. The process represents the juxtaposition of the scholar practitioner. The key components are "sensemaking, relating, visioning, and inventing (Ancona et. al., p. 183). I think this represents the journey, in conjunction with Levi's (2014) team dynamics and Northouse's (2016) leadership, the process will continue. The journey continues and will likely never be complete. While this appears on the outside to be a conclusion which, in some ways it is, it is really a beginning. The post EdD era will be interesting. I am excited to strive forward, continue the work of helping others learn, and share my passion for education. 


\section{References}

Alshurman, M. (2015). Democratic education and administration. Procedia-Social and behavioral science, 176(20), 861-869. doi: 10.1016/j.sbspro.2015.01.551

Ancona, D., Malone, T.W., Orlikowski, W., Senge, P. (2011). In praise of the incomplete leader. In HBR's 10 must reads on leadership (pp. 179-196). Boston, MA:

Harvard Business Review Press. (Reprinted from RO7O2E, Originally published in February, 2007).

Aurini, J., \& Quirke, L. (2011). Does market competition encourage strategic action in the private sector? Canadian Journal of Sociology, 36(2), 173-197.

Baker, T., Campbell, S., \& Ostroff, D. (2016). Independent school leadership: Heads, boards, and strategic thinking. Peabody Journal of Education, 91(5), 574-587. doi: 10.1080/0161956X.2016.1227165

Balinget, M., Bernstein, L., Davenport, C., Dennis, B., Dewey, C., Fears, D., . . WaxThebodeaux, E. (2018, February 16). What Trump proposed cutting in his 2019 budget. Washington Post. Retrieved from https://www.washingtonpost.com/graphics/2018/politics/trump-budget2019/?utm_term $=.4 \mathrm{c} 0 \mathrm{c} 3 \mathrm{eb} 2 \mathrm{c} 4 \mathrm{e} 4$

Barbour, M. K., \& Reeves, T. C. (2009). The reality of virtual schools: A review of the literature. Computers \& Education, 52, 402-416.

https://doi.org/10.1016/j.compedu.2008.09.009

Berends, M. (2015). Sociology and school choice: What we know after two decades of charter schools. Annual Review of Sociology, 41, 159-180. doi: 10.1146/annurevSoc-072014-112340 
Berger, R. L., \& Winters, J. V. (2016). Does private schooling increase adult earnings? Cohort-level evidence for U.S. states. The Review of Regional Studies, 26, 281294.

Bolden, R. (2011). Distributed leadership in organization: A review of theory and research. International Journal of Management Review, 13, 251-269. doi: $10.1111 / \mathrm{j} .1468-2370.2011 .00306 . x$

Bolman, L. G., \& Deal, T. E. (2013). Artistry, choice \& leadership: Reframing organizations. (5th ed.). San Francisco, CA: Jossey-Bass.

Bradley-Levine, J. \& Mosier, G. (2017). Examination of the new tech model as a holistic democracy. Democracy \& Education, 25(1) 1-13.

Brower, H.H., Schoorman, D.F., Tan, H.H. (2000). A model of relational leadership: The integration of truest and leader-member exchange. Leadership Quarterly, 11(2), 227-250.

Bush, T. (2011). Theories of educational leadership \& management. (4th ed.). Los Angeles, CA: Sage.

Bush, T., \& Glover, D. (2014). School leadership models: What do we know? School Leadership \& Management, 34(5), 553-571. doi: 10.1080/13632434.2014.92860

Butler, J.S., Carr D.A., Toma, E.F., \& Zimmer, R. (2013) Choice in a world of new school types. Journal of Policy Analysis and Management, 32(4), 785-806. doi: 10.1002/pam.21711

Carpenter, D. M., II, \& Kafer, K. (2012). A history of private school choice. Peabody Journal of Education, 87, 336-350. https://doi.org/10.1080/0161956X.2012.679587 
Chakrabati, R., Roy, J. (2016). Do charter school crowd out private school enrollment? Evidence from Michigan. Journal of Urban Economics, 91, 88-103. doi: 10.1016/j.jue.2015.10.004

Colombo, H. (2017, March 27). A wise investment? Indianapolis Business Journal, pp. $31-34$.

Conklin, J. (2017, November 14). 30 under 30 education 2018: Young leaders who are expanding access and opportunity. Forbe's. Retrieved from https://www.forbes.com/sites/justinconklin/2017/11/14/30-under-30-education2018-young-leaders-who-are-expanding-access-and-opportunity/\#56179bfe2db5

Cooper, K.S. (2014). Eliciting engagement in the high school classroom: A mixed methods examination of teaching practices. American Education Research Journal, 5l(2), 363-402. doi: 10.3102/0002831213507973

Cooper, B. S., \& Randall, E. V. (2008). Fear and privatization. Educational Policy, 22(1), 204-227. doi: $10.1177 / 0895904807311303$

Creswell, J. W. (2014). Research design: Qualitative, quantitative, and mixed methods approaches. (4th ed.) [Nook].

Creswell, J. W., \& Poth, C. N. (2018). Qualitative inquiry \& research design: Choosing among the five approaches. Los Angeles, CA: Sage Publications.

Darling-Hammond, L. (2017, March 27). Education for sale? The Nation. 16-20.

Darling, A., \& Gelernter, C. (2017, Summer). The micro wave: Seattle's lakeside school embraces a new education model. Independent School Magazine, Retrieved from https://www.nais./magazine/independent-school/summer-2017/the-micro-wave/ 
Devilliers, E.D. \& Pretorius, S.G., (2011) Democracy in schools: Are educators ready for teacher leadership? South African Journal of Education, 31. 574-589.

Dewey, J. (2008) Democracy and education. Retrieved from https://www.gutenberg.org/files/852/852-h/852-h.htm (original work published in 1916)

DiPerna, P. \& Catt, A. (2016). 2016 Schooling in America survey: Public opinion on K12 education and school choice. Retrieved from EdChoice website: https://www.edchoice.org/wp-content/uploads/2016/11/2016-10_SIA-PollUpdate.pdf

Dronkers, J., \& Robert, P. (2008). Differences in scholastic achievement of public, private government dependent, and private independent schools: A cross-national analysis. Educational Policy, 22(4), 541-577. doi: 10.1177/08904807307065

Duignan, P. (2014). Authenticity in educational leadership: History, ideal, reality. Journal of Educational Administration, 52(2), 152-172. Doi: 10.1108/JEA-012014-0012

Eckes, S. E., Mead, J., \& Ulm, J. (2016). Dollars to discriminate: The (un)intended consequences of school vouchers. Peabody Journal of Education, 91(4), 537-558. doi: 10.1080/0161956X.2016.1207446

Edwards, D. (2014, October 17). American schools are training kids for a world that doesn't exist. Wired. Retrieved from https://www.wired.com/2014/10/on-learningby-doing/ 
Egalite, A. J., \& Wolf, P. J. (2016). A review of the empirical research on private school choice. Peabody Journal of Education, 91(4), 441-454. doi:

10.1080/0161956X.2016.1207436

Farber, J. (2012, Fall) The independent school financial model is broken. Independent School. Retrieved from https://www.nais.org/magazine/independent-school/fall2012/the-independent-school-financial-model-is-broken/

Federation for Children. (n.d.). School choice in America. Retrieved January 26, 2019, from https://www.federationforchildren.org/school-choice-america/

Fink, A. (2017). How to conduct surveys: A step by step guide ( $6^{\text {th }}$ ed.). Los Angeles, CA. Sage

Flanngan, C. (2015). Youth find meaning through a larger sense of community. American Journal of Orthopsychiatry, 85(6) S70-S78. doi: 10.1037/ort0000105

Gandolfi, F. \& Stone, S. (2018). Leadership, leadership styles, and servant leadership. Journal of Management Research 18(4). 261-269.

George, B., Sims, P., McLean, A., Mayer, D. (2007). Discovering your Authentic leadership. In HBR's 10 must reads on leadership (pp.163-17). Boston, MA: Harvard Business Review Press. (Reprinted from RO7O2H, Originally published in February 2007) Harvard Business Review, 163-178.

Goleman, D. (2011). What makes a good leader? In In HBR's 10 must reads on leadership (pp. 1-21). Boston, MA: Harvard Business Review Press. (Reprinted from $\mathrm{RO} 4 \mathrm{OlH}$, Originally published in June, 1996)

Goleman, D., \& Senge, P. M. (2014). The triple focus: A new approach to education. Florence, MA: More than Sound. 
Graen, G.B., Uhl-Bien, M. (1995). Relationship-based approach to leadership: Development of leader member exchange (LMX) theory of leadership over 25 years: Applying a multi-level multi-domain perspective. Leadership Quarterly, 26(2), 219-247.

Gray, P. (2017). Self-directed education- Unschooling and democratic schooling. Oxford Research Encyclopedia of Education. Doi:10.1093/acrefore/9780190264093.013.80

Gray, P. \& Chanoff, D. (1986) Democratic school: What happens to young people who have charge of their own education? American Journal of Education, 94(2), 182213

Hands, C. (2014). Collaboration in education: Are students innovative developers, active participants, or passive observers of collaborative activities? The School Community Journal. 24(1), 69-98.

Harris, A. (2013) Distributed leadership: Friend or Foe? Educational Management Administration \& Leadership, 41(5), 545-554. doi: 10.1177/1741143213497635

Harris, A., Leithwood, K., Day, C., Sammons, P., Hopkins, D. (2007). Distributed leadership and organizational change: Reviewing the evidence. Journal of Educational Change. 8. 337-347. doi: 10.1007/s10833-007-9048-4

Hatch, M.J., Schultz, M. (2002). The dynamics of organizational identity. Human Relations, 55(8). 989-1018. doi: 10.1177/0018726702055008181

Hiatt-Michael, D.B. (2001). Schools as learning communities: A vision for organic school reform. The School Community Journal ,11(2), 113-127. 
Heiffetz, R.A., Grashow, A., \& Linsky, M. (2009) The practice of adaptive leadership: Tools and tactics for changing your organization and the world. Boston, MA.: Harvard Business Press.

Heiffeitz, R. A., \& Laurie, D. L. (2011). The work of leadership. In In HBR's 10 must reads on leadership (pp. 57-78). Boston, MA: Harvard Business Review Press. (Reprinted from RO111K, Originally published in January, 1997)

Hentschke, G. C., \& Wohlstetter, P. (2007). K-12 private education in a broader privatization context. Educational Policy, 21(1), 297-307. https://doi.org/10.1177/0895904806298642

Hoerle, H. (2015). Sizing up the competition: Exploring educational choice in today's independent school market. (Report), The Enrollment Management Association.

Hope, M. (2012). The importance of belonging: Learning from the student experience of democratic education. Journal of School Leadership. 22(4), 733-750.

Horn, M. B. (2015, Summer). The rise of AltSchool and the other Micro Schools. Education Next, 15(3). Retrieved from http://educationnext.org/rise-microschools/

Hudson Valley Sudbury School. (n.d.) Retrieved from: https://sudburyschool.com Jabbar, H., \& Li, D. M. (2016). Multiple choice: How public school leaders in New Orleans' saturated market view private school competitors. Education Policy Analysis Archives, 24(94), 1-24. https://doi.org/10.14507/epaa.242382

Jorgenson, O. (2006). Going private? Insights for public School leaders considering the move to independent schools. The Clearing House, 79(6), 265-270. Retrieved from http://www.jstor.org/stable/30182142 
Kofman, F., \& Senge, P.M., (1993) Communities of commitment: The heart of learning organizations. Organizational dynamics, 22(2), 5-23. doi: 10.1016/00902616(93)90050-B

Korkmaz H.E. \& Erden, M. (2014) A delphi study: The characteristics of democratic schools. The Journal for Educational Research, 107, 365-373.

Kowch, E. (2009) New capabilities for cyber charter school leadership: An emerging imperative for integrating educational technology and educational leadership knowledge. TechTrends, 53(4), 41-48.

Krueger, R.A. \& Casey, M.A. (2015) Focus groups: A practical guide for applied research ( $5^{\text {th }}$ ed.). Los Angeles, CA: Sage.

Lapowsky, I. (2015, May 4). Inside the school Silicon Valley thinks will save education. Wired. Retrieved from https://wired.com/2015/05/altschool/

Leadership for Educational Equity (Producer). (2017, February 15). The leaders' table: Matt Candler of 4.0 schools [Show \#13]. The Leaders' Table.

Leithwood, K., Mascall, B., Straus, T., Memon, N., \& Yashkina, A. (2007). Distributing leadership to make schools smarter: Taking the ego out of the system. Leadership and Policy in School, 6(1), 37-67. doi.org/10.1080/157007600601091267

Leithwood, K., Sun, J., \& Pollock, K. (Eds.). (2017). How school leaders contribute to student success: The four paths framework. New York, NY: Springer. https://doi.org/10.1007/978-3-319-50980-8

Levi, D. (2014). Group dynamics for teams (4th ed.). Los Angeles, CA: Sage. 
Loeb, S., Valant, J., \& Kasman, M. (2011). Increasing choice in the market for schools: Recent reforms and their effects on student achievement. National Tax Journal, 64(1), 141-164. doi: 10.1080/03050068.2017.1323822

Martin, A.J., \& Dowson, M. (2009) Interpersonal relationships, motivation, engagement, and achievement: Yields for theory, current issues, and education practice. Review of Educational Research, 79(1), 327-365. doi: 10.3102/0034654308325583

McCormick, P. R. (2017). Leadership in democratic schools (Doctoral dissertation). Available from ProQuest Dissertations and Theses database. (UMI No. 10602433)

McFarland, J., Hussar, B., Wang, X., Zhang, J., Wang, K., Rathbun, A,. Barmer, A., Bullock, F. (2018). The Condition of Education 2018 (NCES 2018-144). U.S. Department of Education. Washington, DC: National Center for Education Statistics. Retrieved from https://nces.ed.gov/pubsearch/pusinfor.asp?pubid=2018144

McShane, M. Q., \& Eden, M. (2015). Encouraging efficiency, rewarding quality: Lessons for school choice policy and practice. Journal of School Choice, 9(1), 97-114. doi: $10.1080 / 15582159.2015 .998968$

Menashy, F. (2014). Theorizing privatization in education: Comparing conceptual frameworks and the value of the capability approach. Current Issues in Comparative Education, 16(1), 13-25. doi.org/10.1080/03050068.2017.1323822

Merriam, S. B., \& Tisdell, E. J. (2016). Qualitative research: A guide to design and implementation (4th ed.). San Francisco, CA: Jossey-Bass. 
Morrison, K.A. (2005). Do free schools promote chaos? A study of the Albany free school. Encounter: Education for meaning and Social justice, 18(1), 25-34.

Moustakas, C. (1994). Phenomenological research methods. Thousand Oaks, CA: Sage.

National Association of Independent Schools. (n.d.). About. Retrieved August 11, 2017, from https://www.nais.org

Northouse, P. G. (2016). Leadership: Theory and practice (7th ed.). Los Angeles, CA: Sage.

Omilion-Hodges, L.M., Baker, C.R. (2017). Communicating leader-member relationship quality; The development of leader communication exchange scales to measure the relationship building maintenance through exchange of communication-based goods. International Journal of Business Communication, 54(2), 115-145. doi: $10.1177 / 2329488416687052$

Patton, M. Q. (2015). Qualitative research \& evaluation methods: Integrating theory and practice (4th ed.). Thousand Oaks, CA: Sage Publications.

Preskill, S., \& Brookfield, S. D. (2009). Learning as a way of leading: Lessons from the struggle for social justice. San Francisco, CA: Jossey-Bass.

Prothero, A. (2016, January 26). Micro schools could be new competition for private k12. Education Week, p. 11. Retrieved from http://edweek.org/ew/articles/2016/01/27/micro-schools-could-be-newcompetion-for.html

Rath, T. (2007). Strengths finder 2.0. New York: Gallup Press. 
Ratnavale, S. (2017). OESIS learning innovation report on U.S. independent schools. Retrieved from Online Education Symposium for Independent Schools website: http://www.oesisgroup.org

Richardson, J., Beck, D., LaFrame, J., \& McLeod, S. (2016). Job attainment and perceived differences in cyber school leaders. Educational Technology \& Society, 19(1), 211-222.

Schuermann, P. R., \& McGovern, M. (2016). Introduction to independent schools: Issues and opportunities. Peabody Journal of Education, 91(5), 569-573. doi:

10.1080/0161956X.2016.1227160

Schulte, L., Shanahan, S., Anderson, T.D., Sides, J. (2003) Student and teacher perceptions of their middle and high schools' sense of community. School Community Journal, 13(1), 7-34.

Schultz, J. R., (2010). The scholar-practitioner: A philosophy of leadership. ScholarPractitioner Quarterly, 4(1), 52-64

Shakeel, M. D., \& DeAngelis, C. A. (2017). Who is more free? A comparison of decision making of private and public school principals. Journal of School Choice, 11(4), 426-445. doi: 10.1080/15582159.2017.1345235

Siedman, I. (2013). Interviewing as qualitative research: A guide for researchers in education \& the social sciences. New York, NY: Teachers College Press.

Spillane, J.P., Halverson, r., \& Diamond, J.B. (2001) Investigating school leadership practice; A distributed perspective. Education Researcher, 30(3). 23-28. doi: 10.3102/0013189X030003023 
Stephenson, K. (2009). Neither hierarchy nor network: An argument for heterarchy. People and Strategy, 32(1), 4-7.

Strike, K. (2008). Small schools: Size or community? American Journal of education. 114(3), 169-190. doi: 10.1086/529499

Summerhill School. (n.d.). Retrieved from www.summerhillschool.co.uk/anoverview.php

Tanz, J. (2015, October 26). The tech elite's quest to reinvent school in its own image. Wired. Retrieved from https://www.wired.com/2015/10/salman-khan-academylab-school-reinventing-classrooms/

Uhl-Bien, M., Marion, R., McKelvey, B., (2007). Complexity leadership theory: Shifting leadership from the industrial age to the knowledge era. The Leadership Quarterly, 18, 298-318. doi: 10.1016/j.leaqua.2007.04.002

Wallin, D. (2003). Student leadership and democratic schools: A Case Study. NASSP Bulletin. 87(636), 55-78. doi:10.1177/0192636503087636606

Woods, P. A., \& Woods, G. J. (2012). Degrees of school democracy: A holistic framework. Journal of School Leadership, 22(4), 707-732.

Woyach, R. (1992, September). Leadership in civic education (ERIC Digest No. ED351270). Retrieved from: https://files.eric.ed.gov/fulltext/ED351270.pdf Yin, R. (2014). Case study research: Design and methods (5th ed.). Los Angeles, CA: Sage Publications. 
Appendix A: Participant Consent Form

\title{
Consent Form to Participate in a Research Study
}

\author{
Researcher's Name(s): Tara J Bonebrake \\ Project Title: A MIXED METHOD PHENOMENOLOGICAL CASE STUDY OF \\ HOW MEMBERS OF A DEMOCRATIC MICRO SCHOOL EXPERIENCE \\ LEADERSHIP AND DEMOCRATIC PRINCIPLES
}

\section{INTRODUCTION}

You are being asked to participate in a research study. This research is being conducted to better understand how community members experience leadership in a democratic micro school. When you are invited to participate in research, you have the right to be informed about the study procedures so you can decide whether you want to consent to participation. This form may contain words that you do not know. Please ask the researcher to explain any words or information that you do not understand.

You have the right to know what you will be asked to do so you can decide whether or not to be in the study. Your participation is voluntary. You do not have to be in the study if you do not want. You may refuse to be in the study and nothing will happen. If you do not want to continue to be in the study, you may stop at any time without penalty or loss of benefits to which you are otherwise entitled.

\section{WHY IS THIS STUDY BEING DONE?}

The purpose of this research is to develop a better understanding of leadership and democratic principles are experienced in a democratic micro school.

\section{HOW MANY PEOPLE WILL BE IN THE STUDY?}

About 42 people will take part in this study.

\section{WHAT AM I BEING ASKED TO DO?}

You will be asked to complete a written survey which will take 20-30 minutes to complete. At the end of the survey you may also choose to participate in a focus group discussion. The focus group discussion is expected to last between 45 and 60 minutes.

\section{HOW LONG WILL I BE IN THE STUDY?}

This study will take approximately an hour and a half to complete. You can stop participating at any time without penalty. Observations could include up to six hours of time but will not disrupt your regular schedule.

\section{WHAT ARE THE RISKS OF BEING IN THE STUDY?}


The risks of this study could include moments of discomfort during focus group due to the statements or experiences of other focus group members.

\section{WHAT ARE THE COSTS OF BEING IN THE STUDY?}

There is no cost to you.

\section{CONFIDENTIALITY}

We will do our best to make sure your answers to the survey questions are kept private. Individual statements may be used in the findings of the research; however, little or no identifiable information will be shared beyond member position (parent, student, educator). Information produced by this study will be stored in the investigator's file in a locked office.

You will be audio recorded during the focus group interview. Your statements may be used in the final research however, they will not be identified beyond your role (educator/parent).

\section{WILL I BE COMPENSATED FOR PARTICIPATING IN THE STUDY?}

You will receive no payment for taking part in this study.

\section{WHAT ARE MY RIGHTS AS A PARTICIPANT?}

Participation in this study is voluntary. You do not have to participate in this study. You will also be informed of any new information discovered during the course of this study that might influence your health, welfare, or willingness to be in this study.

\section{WHO DO I CONTACT IF I HAVE QUESTIONS, CONCERNS, OR COMPLAINTS?}

Please contact Tara Bonebrake (417) 836-3222 or Jeffrey Cornelius-White jcorneliuswhite@missouristate.edu if you have questions about the research. Additionally, you may ask questions, voice concerns or complaints at any time.

\section{WHO DO I CALL IF I HAVE QUESTIONS OR PROBLEMS?}

If you have any questions regarding your rights as a participant in this research and/or concerns about the study, or if you feel under any pressure to enroll or to continue to participate in this study, you may contact the University of Missouri Institutional Review Board (which is a group of people who review the research studies to protect participants' rights) at (573) 882-3181 or umcresearchcirb@missouri.edu. You may ask more questions about the study at any time. For questions about the study or a research-related 
injury, contact Tara Bonebrake at (417) 836-3222 or tjbzp5@mail.missouri.edu or Jeffrey Cornelius-White at jcornelius-white@missouristate.edu

I have read this consent form and my questions have been answered. By clicking A copy of this Informed Consent form will be given to you before you participate in the research. I know that I can remove myself from the study at any time without any problems.

Please note that this survey will be best displayed on a laptop or desktop computer. Some features may be less compatible with a mobile device. 
Appendix B- Parent consent

PARENTAL Consent Form to PARTicipate in A ReSEARCH STUdy

INVESTIGATOR'S NAME: TARA J. BONEBRAKE

STUDY TITLE: A MIXED METHOD PHENOMENOLOGICAL CASE STUDY OF

HOW MEMBERS OF A DEMOCRATIC MICRO SCHOOL EXPERIENCE

LEADERSHIP AND DEMOCRATIC PRINCIPLES

INTRODUCTION

I ask for permission that your child be allowed to participate in a research study. This research is being conducted to better understand how community members experience leadership in a democratic micro school. You have the right to be informed about the study procedures so you can decide whether you want to consent for your child to participate in this research study. This form may contain words you do not know.

Please ask the researcher to explain any words or information that you do not understand.

You have the right to know what your child will be asked to do so you can decide whether or not to include your child in the study. Your child's participation is voluntary. They do not have to be in the study if they do not want to. You may refuse for your child to be in the study and nothing will happen. If your child does not want to continue to be in the study, they may stop at any time without penalty or loss of benefits to which they are otherwise entitled.

I ask that you read this form and ask any questions you may have before allowing your child to participate in this study.

\section{DESCRIPTION OF THE RESEARCH}

Your child has been invited to be in this study because they are currently or were once a member of the [Name of School] community. The purpose of this research is to develop a better understanding of how members of a democratic micro school community experience leadership and democratic principles.

\section{PROCEDURES OF THE STUDY}

If you agree to have your child be a part of the study, they will be asked to do the following things: Complete a survey and they may also participate in a 6-10 person focus group. The survey should take between 20-30 minutes to complete, and the focus group will last from 45-60 minutes. Your child may also be observed for up to six hours during the school day. These observations will not disrupt their normal school day.

\section{HOW LONG WILL MY CHILD BE IN THE STUDY?}

This study will take approximately an hour and a half to complete. Your child can stop participating at any time without penalty. 


\section{WHAT ARE THE BENEFITS OF THE RESEARCH?}

Your child's participation will provide the opportunity for your child to better understand the academic research process for a doctoral student.

\section{WHAT ARE THE RISKS OF THE RESEARCH?}

Your child could potentially be offended or hurt by their statements or the statements of other community members during the focus group interview.

\section{PARTICIPATION IS VOLUNTARY}

Participation in this research study is voluntary. You may refuse to allow your child to participate or withdraw your child from the study at any time. Your child may also refuse to participate or withdraw themselves at any time. Your child will not be penalized in any way if you decide not to allow your child to participate or to withdraw your child from this study.

\section{WHAT ABOUT CONFIDENTIALITY?}

Data from the survey will likely be included in the final paper. However, information beyond your child as a student and the number of years they have attended the school will not be collected. Information produced by this study will be stored in the investigator's file in a locked office.

Your child will be audio recorded during the focus group interview. Their statements may be used in the final research however, they will not be identified beyond their role as a student.

\section{WHO CAN I TALK TO ABOUT THE STUDY?}

If you have any questions about the study or if you would like additional information, please call Tara Bonebrake at (417) 836-3222 or email at tjbzp5@mail.missouristate.edu or Jeffrey Cornelius-White at jcornelius-white@missouristate.edu

You may contact the University of Missouri Institutional Review Board (which is a group of people who review the research studies to protect participants' rights) if you have questions regarding your child's rights as a research and/or concerns about the study, or if you feel under any pressure to enroll your child or to continue to participate in this study. The IRB can be reached directly by telephone at (573)882-9585 and e-mail umcresearchcirb@missouri.edu

\section{CONSENT}

I have read this parental consent form and have been given the opportunity to ask questions. I give my permission for my child to participate in this study. I understand that, in order to for my child to participate, they will need to be able to give their consent also. I understand participation is voluntary and I can withdraw my child at any time without penalty or loss of benefits. You will be informed of any significant new findings discovered during the course of this study that might influence your child's health, welfare, or willingness to continue participation in this study. Date: 
Child's Name: 
Appendix C: Child Assent Form

\title{
ChILd Assent Form to PARTicipate in A ReSEARCH STUdy
}

\author{
INVESTIGATOR'S NAME: TARA J BONEBRAKE
}

\author{
STUDY TITLE: A MIXED METHOD PHENOMENOLOGICAL CASE STUDY OF HOW \\ MEMBERS OF A DEMOCRATIC MICRO SCHOOL EXPERIENCE LEADERSHIP AND \\ DEMOCRATIC PRINCIPLES
}

This is a study about the experiences of being member of a democratic micro school community.

\section{Why YOU are invited}

You are invited to be in this study because you are currently or were a student at the [Name of School].

What will happen?

If you agree to be in the study, you will be asked to do the following things: To complete a 20-30 minute survey that will be completed online. In addition to the survey you may also choose to participate in a 45-60 minute focus group interview. The focus group will be comprised of between 6-10 of your fellow school members.

\section{Can anything good happen to me?}

As a participant in this research study, you will have the opportunity to learn more about the work doctoral students and researchers complete.

\section{Can anything bad happen to me?}

Any time you share something with in a small group, like a focus group, there is the potential you or someone may become upset by something that has been said.

What if I don't want to do this?

If you say you do not want to be in the study, you just have to tell us. No one will be mad at you. You can also say yes and later you change your mind, you can quit the study. The choice is up to you [and your parent(s)]. You may also choose to complete the survey and not participate in the focus group or you may choose to participate in the focus group and not the survey.

Who will have access to my answers and information?

Every attempt will be made to keep identifiable information you share confidential. When the study is complete, Tara Bonebrake may also choose to share the findings with the school community but will not share any personally identifiable information. The findings of the study may also be published in an academic journal.

Who can I talk to about the study?

You can ask questions any time. You can ask now. You can ask later. You can talk to me or you can talk to someone else, at any time during the study. Here is the telephone number to reach us (417) 836-3222 or email me: tjbzp5@,mail.missouri.edu or Jeffery CorneliusWhite at jcornelius-white@missouristate.edu

By signing this, I assent to be a part of this study and understand that I can choose to leave at any time.

Signature of Child:

Date

A copy of this form will be given to you. 


\section{Appendix D: Survey Items}

Survey Items

Identify role: Educator Student Parent Other (specify)

Years affiliated with the [Name of School] $1 \quad \begin{array}{llll}1 & 2 & 3 & \text { More than } 3\end{array}$

Circle the answer the best describes you.

I feel I am a valuable part of the school community.

Strongly disagree disagree slightly disagree slightly agree agree strongly agree

I share similar values with other members of the school community.

Strongly disagree disagree slightly disagree $\quad$ slightly agree agree strongly agree

I feel I am able to share my thoughts in the school community.

Strongly disagree $\quad$ disagree $\quad$ slightly disagree slightly agree agree $\quad$ strongly agree

Members of the community care about me.

Strongly disagree disagree slightly disagree $\quad$ slightly agree agree strongly agree

I feel my thoughts and goals are well understood by the educators at [Name of School].

Strongly disagree $\quad$ disagree $\quad$ slightly disagree slightly agree agree strongly agree

I feel I have control over what I learn in this school community.

Strongly disagree disagree slightly disagree slightly agree agree strongly agree

I listen to other members of the community when they are sharing their thoughts and ideas.

Strongly disagree disagree slightly disagree slightly agree agree strongly agree

I feel I am able to really explore topics of interest in the school community.

Strongly disagree disagree slightly disagree $\quad$ slightly agree agree strongly agree

I feel well supported in the school community.

Strongly disagree $\quad$ disagree $\quad$ slightly disagree slightly agree agree strongly agree

I feel I am a part of the school community. 
Strongly disagree disagree slightly disagree slightly agree agree strongly agree

I feel I am included in important decisions at school.

Strongly disagree disagree slightly disagree slightly agree agree strongly agree

I feel all members of the school are allowed to participate in making important decisions.

Strongly disagree disagree slightly disagree slightly agree agree strongly agree

I use technology regularly as part of my role in the [Name of School] Community.

Strongly disagree disagree slightly disagree slightly agree agree strongly agree

I can trust other members of the community.

Strongly disagree disagree slightly disagree slightly agree agree strongly agree

I feel my potential is understood as a member of the [Name of School] Community.

Strongly disagree disagree slightly disagree slightly agree agree strongly agree

I feel all members of the [Name of School] community are given an equal voice in decision making.

Strongly disagree $\quad$ disagree $\quad$ slightly disagree slightly agree agree strongly agree Other members of the community can trust me.

Strongly disagree disagree slightly disagree slightly agree agree strongly agree I feel I have opportunities for leadership in the [Name of School] community.

Strongly disagree disagree slightly disagree slightly agree agree strongly agree Give examples

I feel positive about my experience at the [Name of School].

Strongly disagree disagree slightly disagree slightly agree agree strongly agree

Please respond to the questions below.

In what ways, if any, do you communicate your thoughts and ideas with other members of the community?

In what ways, if any, do members of the community communicate with you? 
Thank you for your participation in this study. In addition to this survey, I would also like to invite to participate in a focus group. If you are interested in doing so, please give your email address on the next page.

Thank you! 


\section{Appendix E: Focus Group Protocol}

Interview Script

Introduction: Hi, My name is Tara Bonebrake and I am doctoral candidate at the University of Missouri- Columbia. I am currently completing my dissertation: A mixed method phenomenological case study of how members of a democratic Micro School experience leadership and democratic principles. Review of informed consent, with a reminder that participants are allowed to leave at any time.

Interview questions

1) Please tell me a little bit about yourselves and your role at the [Name of School].

2) What do you know about leadership?

3) What role do you think building relationships plays in leadership?

4) What examples of leadership have you seen at the [Name of School]?

5) How do you view your role at the [Name of School]?

6) What role do you think leadership plays at the [Name of School]?

7) How do you think you experience leadership at the [Name of School]?

8) In what ways, if any, are you encouraged to lead at the [Name of School]?

a) Please explain.

9) What do you think are the key attributes of a leader? Follower?

10) What are the most challenging experiences you've had at the [Name of School]?

11) What do you like the most about the [Name of School]?

12) What else would you like to share with me about [Name of School]? 
Location:

Time:

\# of People and Roles:

Physical Description:
Appendix F: Observation Protocol

Date:

Length of Observation:

\begin{tabular}{|c|c|}
\hline & Observational Examples \\
\hline Community & \\
\hline Trust and Caring & \\
\hline Communication & \\
\hline Vision and Goals & \\
\hline Curriculum and Interest & \\
\hline Equity & \\
\hline Other & \\
\hline & \\
\hline & \\
\hline & \\
\hline & \\
\hline & \\
\hline & \\
\hline & \\
\hline & \\
\hline & \\
\hline & \\
\hline & \\
\hline & \\
\hline & \\
\hline & \\
\hline & \\
\hline & \\
\hline
\end{tabular}


Artifact Title:

Artifact Location (Web Address):

Date of Analysis:

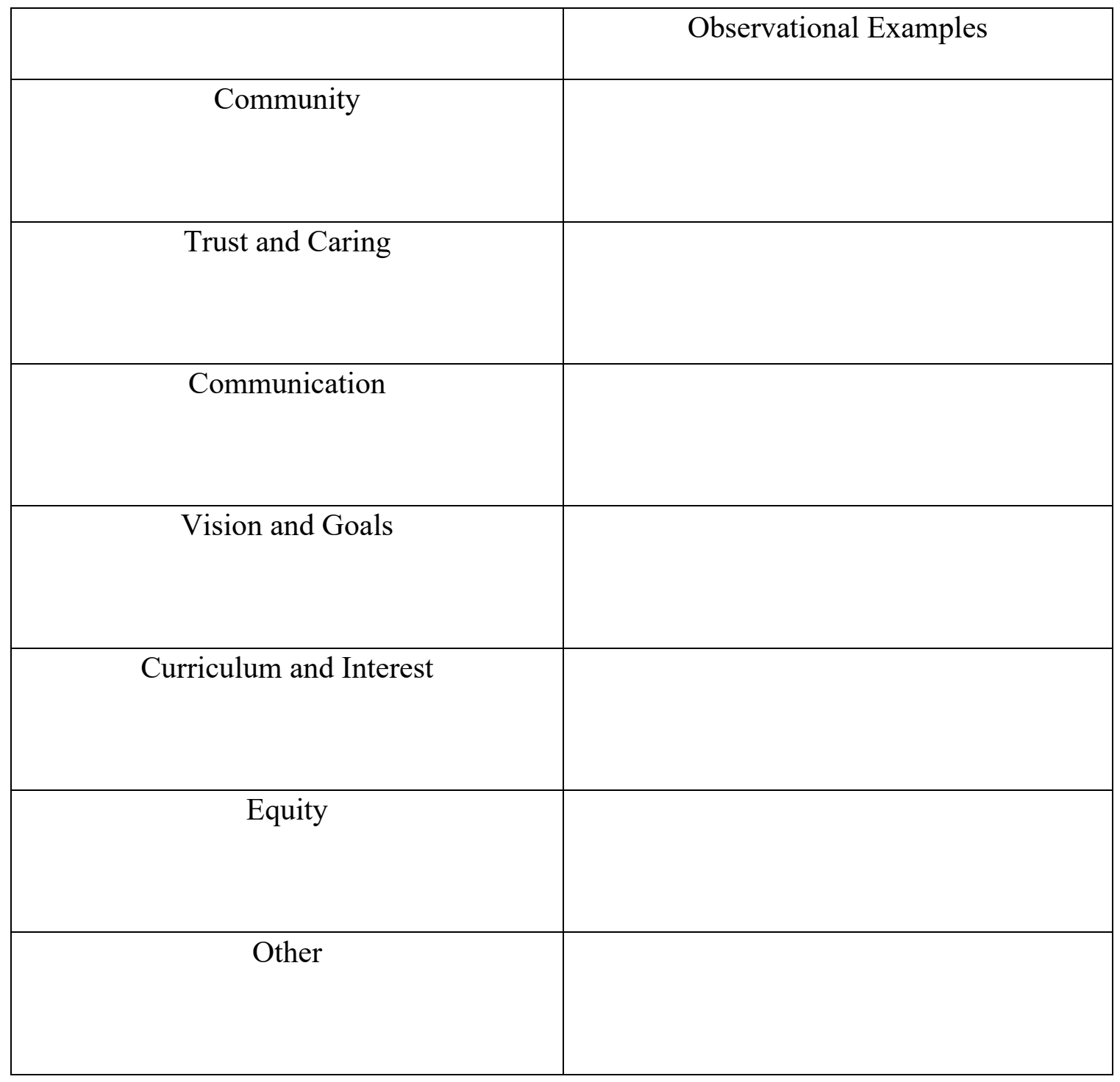




\section{Appendix H- Email Script}

\section{E-mail Script}

\section{Good morning,}

My name is Tara Bonebrake and I am a doctoral student in the department of educational leadership and policy analysis at the University of Missouri-Columbia. I am currently working on my dissertation which means that I am in the final stage of trying to earn my doctorate. My research focus for my dissertation is how members of a democratic micro school experience leadership and democratic principles. You are receiving this email because you have a student who is currently enrolled at the U School.

Today, I am asking for your participation in my study. There are two parts to my study. Each part requires direct participation and include a survey and focus group. Participation in the focus group is optional after completing the survey. You will be asked at the end of the survey to supply contact information if you are interested and willing to participate in this focus group.

Participation in this study is completely voluntary and I would certainly appreciate your help in completing my research. The survey will take 15 to 20 minutes to complete, if you decide to also participate in the focus group, that will be an addition 45-60 minutes. If you are willing to complete survey, please click the link below and it will take you to the survey.

\section{Click Here to go to the Survey}

Thank you very much.

Cheers,

Tara Bonebrake

Educational Leadership and Policy Analysis Doctoral Student University of Missouri-Columbia 


\section{VITA}

Tara Bonebrake was born in St. Louis, Missouri and moved to Springfield, Missouri at a young age. She graduated from Greenwood Lab School and chose to stay in Springfield to study at Drury University. Upon graduating from Drury, she moved to St. Petersburg, Florida where she studied marine science at Eckerd College. She discovered her love of teaching while an Americorps volunteer at Academy Prep Center for Education. While there, she taught social studies and science to middle school students. In addition to teaching, she also supported student activities beyond the classroom including sailing, cheerleading, and swimming. She left Academy Prep to attend Washington University in St. Louis. She graduated from Wash U with a Master of Arts in Teaching where she focused on middle school science and social studies. Her first two teaching positions were teaching middle school science at Windsor Middle School and Jennings Junior High respectively. Eventually, she became a teacher at Mary Instituted and St. Louis Country Day School where she taught middle school science, coached middle school soccer, and assisted both the junior varsity soccer and tennis teams' coaches. She also had the opportunity to travel to Little Cayman Research Center to indoctrinate future scholars with marine science research methods. Today, she resides in Springfield, Missouri, where she is a science teacher at Greenwood Lab School. In addition to teaching, she also sponsors cheerleading and coordinates the $6^{\text {th }}-12^{\text {th }}$ grade science Olympiad team. Bonebrake loves to offer new and different experiences to student both in and out of the classroom. She plans to continue her work in K-12 education. 